\section{SANDIA REPORT}

SAND96-2269 • UC-630

Unlimited Release

Printed September 1996

\title{
1995 Site Environmental Report Tonopah Test Range Tonopah, Nevada
}

RECFIVED

OCT 151996

OSTI

\section{T. Culp, W. Forston}

\author{
Prepared by \\ Sandia National Laboratories: \\ Albuquerque, New Mexico,87185 and Livermore, California 94550 \\ for the United States Department of Energy \\ under Contract DE-AC04-94AL85000
}

Approved for public release; distribution is unlimited.

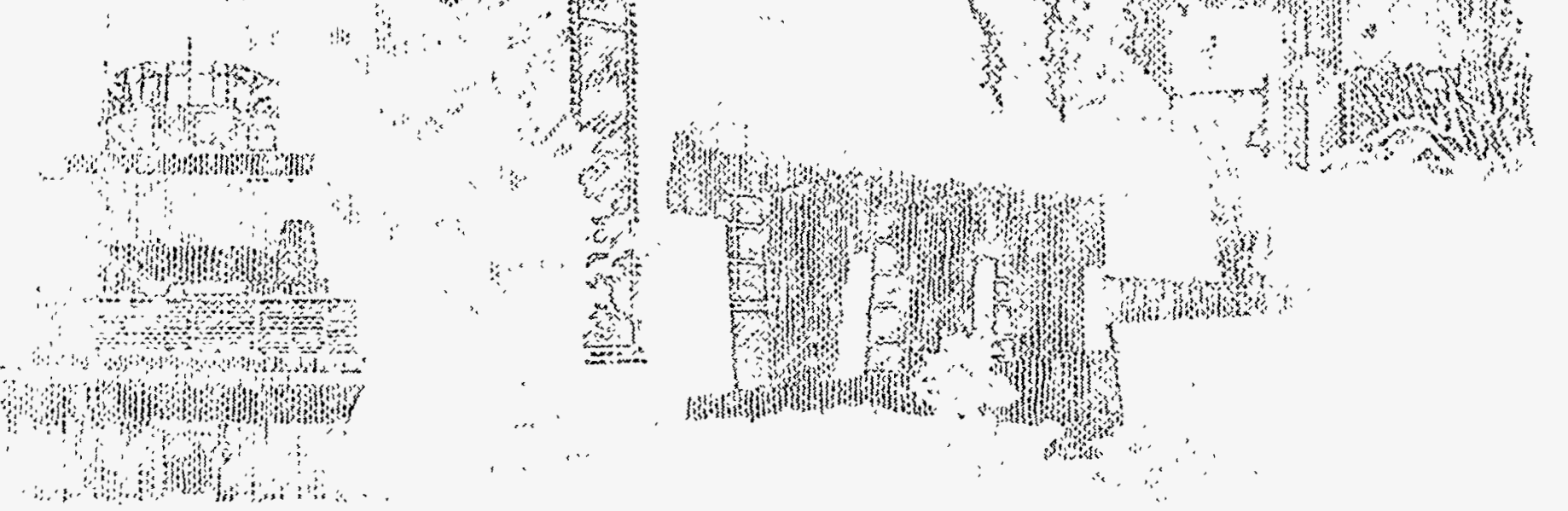



SAND96-2269

Distribution

Unlimited Release

Printed September 1996

Category UC-630

\title{
1995 SITE ENVIRONMENTAL REPORT TONOPAH TEST RANGE TONOPAH, NEVADA
}

\author{
T. Culp \\ Air Quality Department \\ Sandia National Laboratories \\ Albuquerque, NM 87185 \\ W. Forston \\ Kirk-Mayer, Inc. \\ Tonopah, NV 89049
}

\begin{abstract}
This report summarizes the environmental surveillance activities conducted by Sandia National Laboratories, and Kirk-Mayer, Inc., for the Tonopah Test Range operated by Sandia National Laboratories. Sandia National Laboratories' responsibility for environmental surveillance results extends to those activities performed by Sandia National Laboratories or under its direction. Results from other organizations environmental surveillance activities are included to provide a measure of completeness. Other environmental compliance programs such as the National Environmental Policy Act of 1969, environmental permits, and environmental restoration and waste management programs are also included in this report, prepared for the U.S. Department of Energy (DOE) in compliance with DOE Order 5400.1.
\end{abstract}




\section{ACKNOWLEDGMENTS}

The authors thank those people who provided information and analytical data necessary for preparation of this report.

Rebecca Sanchez of InfoMatrix provided technical word processing. Dianne Duncan of GRAM, Inc. provided editorial support, technical editing, and coordinated document production.

\section{NOTE TO THE READER}

If you have comments or questions about this report, or need further information, contact:

Sandia National Laboratories

Media Relations Department

MS 0167

P.O. Box 5800

Albuquerque, NM 87185

(505) 844-4207 or

(505) $844-2282$ 


\section{DISCLAIMER}

Portions of this document may be illegible in electronic image products. Images are produced from the best available original document. 


\section{CONTENTS}

Page

1.0 EXECUTIVE SUMMARY $1-1$

1.1 Assessment of Potential Dose to the Public..................................................... 1-1

1.2 Overview of 1995 Surveillance Results ............................................................ 1-1

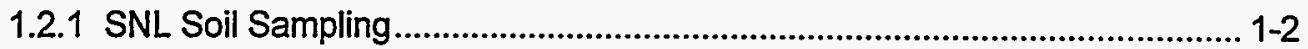

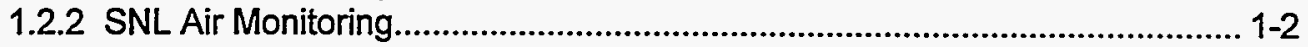

1.2.3 Wastewater Sampling Program ............................................................... 1-2

1.2.4 Drinking Water Sampling Program ....................................................... 1-2

1.2.5 Hazardous Waste Program ..................................................................... 1-3

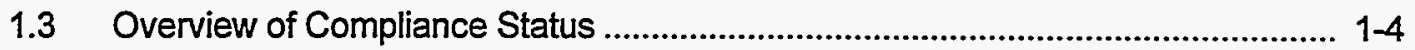

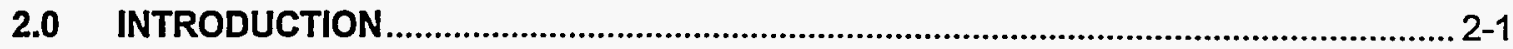

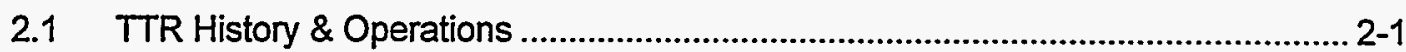

2.2 Location and Population .................................................................................... 2-1

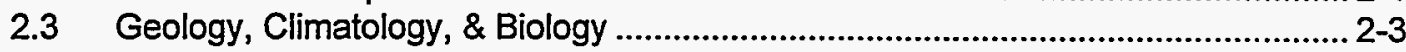

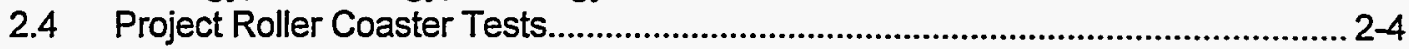

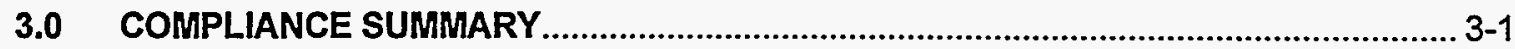

3.1 Environmental Restoration Activities .............................................................. 3-1

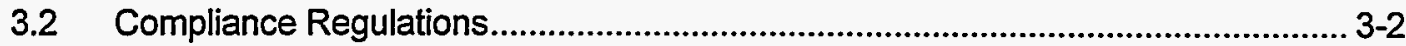

3.2.1 Comprehensive Environmental Response, Compensation and Liability Act (CERCLA) \& Super-fund Amendments and Reauthorization Act (SARA)

3.2.2 Resource Conservation and Recovery Act (RCRA)................................. 3-2

3.2.3 Clean Air Act (CAA) ............................................................................ 3-2

3.2.4 Clean Water Act (CWA)..................................................................... 3-3

3.2.5 Safe Drinking Water Act (SDWA) ......................................................... $3-3$

3.2.6 Toxic Substances Control Act (TSCA) .................................................. 3-4

3.2.7 Federal Insecticide, Fungicide, and Rodenticide Act (FIFRA) ................. 3-4

3.2.8 Endangered Species Act (ESA) ......................................................... 3-4

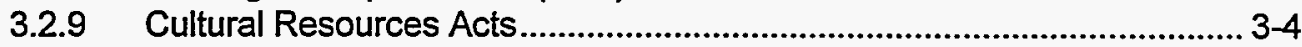

3.2.10 Executive Orders.............................................................................. $3-5$

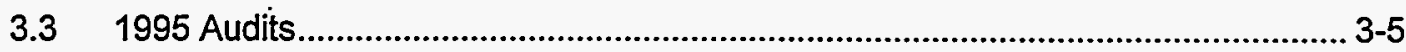

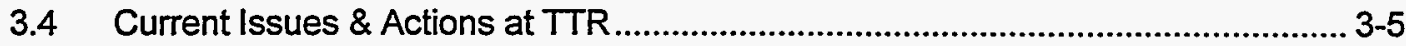

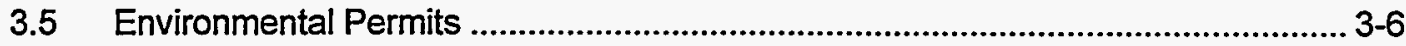




\title{
CONTENTS
}

\author{
(Continued)
}

4.0 OTHER ENVIRONMENTAL PROGRAMS ................................................................ 4-1

4.1 Spill Prevention Control \& Countermeasures Plan ...........................................4-1

4.2 Waste Management Programs ........................................................................... 4-1

4.2.1 Chemical \& Hazardous Waste Management ............................................4-1

4.2.2 Waste Minimization Program ...................................................................4-4

4.3 Environmental Restoration Project...................................................................4-5

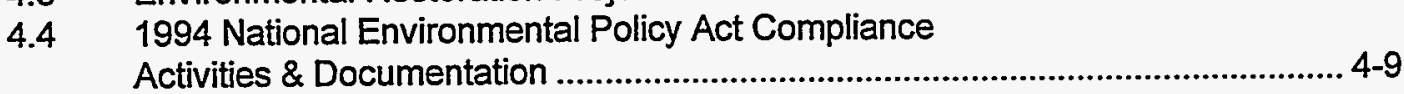

4.4.1 Compliance Summary ..................................................................... 4-10

4.4.2 Environmental Checklist.................................................................... 4-10

4.4.3 Action Description Memorandum....................................................... 4-10

4.4.4 Environmental Assessment.............................................................. 4-11

Overview of Non-SNL Environmental Monitoring
Programs at TTR........................................................................................ 4-11

4.6 1995 Reportable Releases............................................................................ 4-13

4.7 Occurrence Reporting ................................................................................... 4-13

5.0 ENVIRONMENTAL SURVEILLANCE AT TTR IN 1995 .......................................... 5-1

5.1 1995 SNL Environmental Surveillance.............................................................5-1

5.2 1995 SNL Radiological Surveillence Results.........................................................5-3

5.2.1 Soil Sampling ..........................................................................................5-3

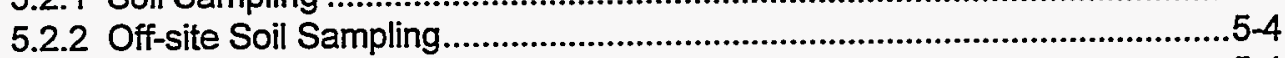

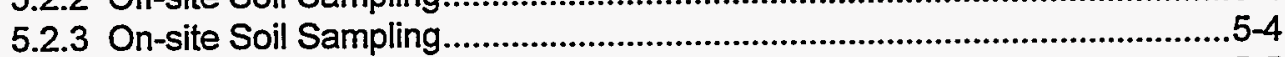

5.2.4 Results of Radiological Air Sampling......................................................5-5

5.2.5 Results of the TLD Program Sampling ........................................................5-5

5.3 1995 SNL Non-radiological Surveillance Results ............................................. 5-12

5.3.1 Soil Sampling........................................................................................ 5-12

5.3.2 Off-Site Soil Sampling ......................................................................... 5-12

5.3.3 On-Site Soil Sampling ......................................................................5-12

5.3.4 Results of Non-radiological Air Sampling ............................................... 5-14 


\section{CONTENTS}

(Continued)

Page

5.4 Environmental Perspective ........................................................................ 5-14

5.5 KMI Services Monitoring Program .................................................................... 5-22

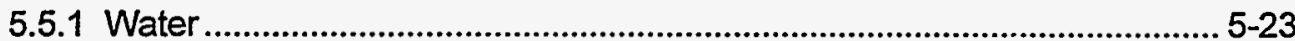

5.5.2 Sewage System................................................................................... $5-24$

5.6 Assessment of Potential Dose to the Public........................................................ 5-25

5.6.1 Receptor Locations................................................................................. $5-25$

5.6.2 Meteorological Data............................................................................ 5-28

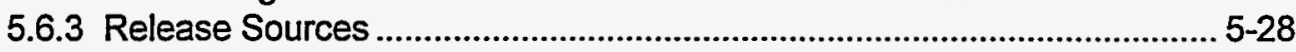

5.6.4 Radiological Dose Assessment ............................................................. 5-28

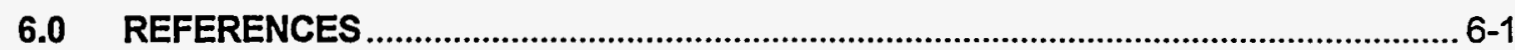

APPENDIX A State of Nevada Regulations and Permit Listings ...............................................

APPENDIX B Radiological Sampling Locations and Results ................................................... B-1

APPENDIXC Non-radiological Analytical Data ........................................................................ 


\title{
CONTENTS
}

\author{
(Continued)
}

\section{FIGURES}

2-1 Location of Tonopah Test Range, Nevada ................................................................ 2-2

2-2 Locations of facilities operated by Sandia National Laboratories

at the Tonopah Test Range

5-1 On-Site Receptor Locations

5-2 Public Receptor Zone Around the Tonopah Test Range

\section{TABLES}

2-1 Project Roller Coaster test information

3-1 Summary of Permit ownership at the TTR

4-1 All RCRA regulated chemical and hazardous waste shipped off-site in 1995 for disposal

4-2 Regulated waste, other than RCRA Waste shipped off-site for treatment and disposal.

4-3 Hazardous and regulated non-RCRA waste shipped off-site in 1995 for recycling.

4-4 Department of Energy Environmental Restoration Division Tonopah

Test Range Corrective Action units and sites

5-1 Radiological Summary Data for Soil Samples Collected at TTR in 1995.

5-2 $\quad \mathrm{PM}_{10}$ Radiological air monitoring results for the 554th Range

Squadron O\&M Complex

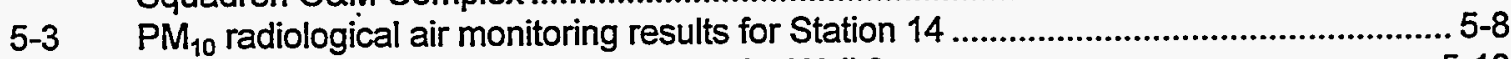

5-4 $\quad \mathrm{PM}_{10}$ radiological air monitoring results for Well 6 ........................................................ 5-10

5-5 Summary of Thermoluminescent Dosimeter Measurements for 1995

5-6 $\quad \mathrm{PM}_{10}$ non-radiological air monitoring results for the 554th Range

Squadron O\&M Complex

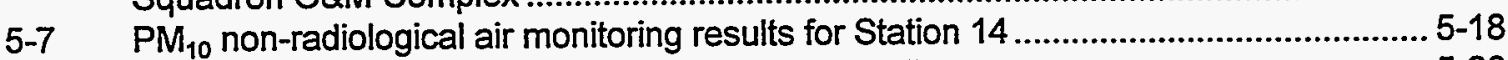

5-8 $\quad \mathrm{PM}_{10}$ non-radiological air monitoring results for Well 6 ............................................... 5-20

5-9 Summary of 1995 SNL/NV public water systems sampling ...........................................5-23

5-10 Summary of 1995 SNL/NV waste-water sampling program ........................................ 5-24 


\section{ABBREVIATIONS}

\section{Units}

$\begin{array}{ll}{ }^{\circ} \mathrm{C} & \text { Celsius degree } \\ \mathrm{cm} & \text { centimeter } \\ \mathrm{cm}^{2} & \text { square centimeter } \\ \mathrm{cm}^{3} & \text { cubic centimeter } \\ { }^{\circ} \mathrm{F} & \text { Fahrenheit degree } \\ \mathrm{ea} . & \text { each } \\ \mathrm{ft} & \text { foot } \\ \mathrm{g} & \text { gram } \\ \mathrm{gal} & \text { gallon } \\ \mathrm{hr} & \text { hour } \\ \mathrm{in} . & \text { inch } \\ \mathrm{kg} & \text { kilogram } \\ \mathrm{km} & \text { kilometer } \\ \mathrm{km} & \text { square kilometer } \\ \mathrm{L} & \text { liter } \\ \mathrm{m} & \text { meter } \\ \mathrm{m}^{2} & \text { square meter } \\ \mathrm{m}^{3} & \text { cubic meter } \\ \mathrm{mg} / \mathrm{m}^{3} & \text { milligrams per cubic meter } \\ \mathrm{mi} & \text { mile } \\ \mathrm{mi} & \text { square mile } \\ \mathrm{m} / \mathrm{s} & \text { meters per second } \\ \mathrm{ppm} & \text { parts per million } \\ \mathrm{sec} & \text { second } \\ \mathrm{sec} / \mathrm{yr} & \text { seconds per year } \\ \mu \mathrm{m} & \text { micron } \\ \mathrm{yr} & \text { year } \\ \mathrm{yd} & \text { cubic yard } \\ & \end{array}$




\section{ABBREVIATIONS}

(Continued)

Frequently Referenced Nuclide Symbols and Components

\begin{tabular}{|c|c|c|c|}
\hline $\mathrm{Al}$ & aluminum & $\mathrm{Pu}-238$ & plutonium-238 \\
\hline Am-241 & americium-241 & Pu-239 & plutonium-239 \\
\hline $\mathrm{Ba}$ & barium & $\mathrm{Pu}-240$ & plutonium-240 \\
\hline $\mathrm{Be}$ & beryllium & $\mathrm{Pu}-241$ & plutonium-241 \\
\hline $\mathrm{Be}-7$ & beryllium-7 & $\mathrm{Pu}-242$ & plutonium-242 \\
\hline $\mathrm{Cd}$ & cadmium & $\mathrm{Ra}-226$ & radium-226 \\
\hline Co & cobalt & $\mathrm{Si}$ & silica \\
\hline $\mathrm{Cr}$ & chromium & Th-232 & thorium-232 \\
\hline Cs-137 & cesium-137 & $\mathrm{Ti}$ & titanium \\
\hline $\mathrm{Fe}$ & iron & $\mathrm{U}$ & uranium \\
\hline $\mathrm{H}-3$ & tritium & U-238 & uranium-238 \\
\hline $\mathrm{K}$ & potassium & $U_{\text {tot }}$ & total uranium \\
\hline $\mathrm{Pb}$ & lead & $\mathrm{Zn}$ & zinc \\
\hline $\mathrm{Pu}$ & plutonium & & \\
\hline
\end{tabular}

\section{Radioactivity Measurements}

$\begin{array}{ll}\mathrm{Ci} & \text { curie (unit of radioactivity) } \\ \mathrm{dpm} & \text { disintegration per minute } \\ \mathrm{mrem} & \text { millirem (unit of radiation dose) } \\ \mathrm{mrem} / \mathrm{yr} & \text { millirem per year } \\ \mathrm{mR} / \mathrm{yr} & \text { milliroentgen per year } \\ \text { person-mrem/yr } & \text { person-millirem per year } \\ \text { person-rem/yr } & \text { person-rem per year } \\ \mathrm{pCi} & \text { picocurie } \\ \mathrm{R} & \text { roentgen (unit of radiation exposure) } \\ \mathrm{rem} & \text { roentgen equivalent man (unit of dose equivalent) } \\ \mu \mathrm{g} / \mathrm{m}^{2} & \text { microgram per square meter } \\ \mu \mathrm{g} / \mathrm{m}^{3} & \text { microgram per cubic meter }\end{array}$




\section{ABBREVIATIONS}

(Continued)

\section{Acronyms}

$\begin{array}{ll}\text { ADM } & \text { Action Description Memorandum } \\ \text { AEC } & \text { U.S. Atomic Energy Commission } \\ \text { AIRFA } & \text { American Indian Religious Freedom Act } \\ \text { ARPA } & \text { Archaeological Resources Protection Act } \\ \text { BLM } & \text { Bureau of Land Management } \\ \text { BOD } & \text { biochemical oxygen demand } \\ \text { CAA } & \text { Clean Air Act } \\ \text { CAU } & \text { Corrective Action Unit } \\ \text { CAS } & \text { Corrective Action Site } \\ \text { CEM } & \text { Certified Environmental Manager } \\ \text { CEQ } & \text { Council on Environmental Quality } \\ \text { CERCLA } & \text { Comprehensive Environmental Response, Compensation and Liability } \\ & \text { Act } \\ \text { CFR } & \text { Code of Federal Regulations } \\ \text { CWA } & \text { Clean Water Act } \\ \text { CY } & \text { calendar year } \\ \text { DAC } & \text { derived air concentration } \\ \text { DCG } & \text { derived concentration guides } \\ \text { DMR } & \text { Discharge Monitoring Report } \\ \text { DOC } & \text { U.S. Department of Commerce } \\ \text { DoD } & \text { U.S. Department of Defense } \\ \text { DOE } & \text { U.S. Department of Energy } \\ \text { DOE/AL } & \text { U.S. Department of Energy/Albuquerque Operations Office } \\ \text { DOE/ERD } & \text { U.S. Department of Energy/Environmental Restoration Department } \\ \text { DOE/HQ } & \text { U.S. Department of Energy/Headquarters } \\ \text { DOE/KAO } & \text { U.S. Department of Energy/Kirtland Area Office } \\ \text { DOE/NV } & \text { U.S. Department of Energy/Nevada Operations Office } \\ \text { DOI } & \text { U.S. Department of the Interior } \\ \text { DRI } & \text { Desert Research Institute, Water Resources Center, University of } \\ & \text { Nevada System } \\ \text { DU } & \text { depleted uranium } \\ \text { EA } & \text { Environmental Assessment } \\ \text { ECL } & \text { Environmental Checklist } \\ \text { EDE } & \text { effective dose equivalent } \\ \text { EG\&G } & \text { Edgerton, Germeshausen \& Grier Corporation } \\ \text { EIS } & \text { Environmental Impact Statement } \\ \text { EPA } & \text { U.S. Environmental Protection Agency } \\ \text { EPCRA } & \text { Emergency Planning and Community Right-to-Know Act } \\ & \\ & \\ & \end{array}$




\section{ABBREVIATIONS}

(Continued)

EPD Environmental Programs Departments

ER Environmental Restoration

ERDA U.S. Energy Research and Development Administration

ES\&H environment, safety and health

ESA Endangered Species Act

FFACO Federal Facilities Agreement and Consent Order

FIDLER field instrument for the detection of low-energy radiation

FIFRA Federal Insecticide, Fungicide, and Rodenticide Act

FONSI finding of no significant impact

FY fiscal year

ICP inductively coupled plasma (method)

ICRP International Commission on Radiological Protection

IT International Technology Corporation

KMI Kirk-Mayer, Inc. (KMI Services)

MDC minimum detectable concentrations

MEI maximum exposed individual

MSDS Material Safety Data Sheet

MSS multispectral scanner

MTF memo-to-file

NA not applicable, not available

NAEG Nevada Applied Ecology Group

NAFB Nellis Air Force Base (Range Complex)

ND Not detected

NDEP Nevada Department of Environmental Protection

NEPA National Environmental Policy Act

NESHAP National Emission Standards for Hazardous Air Pollutants

NF None found

NHPA National Historic Preservation Act

NOS not otherwise specified

NPDES National Pollutant Discharge Elimination System

NTS Nevada Test Site

NV Nevada

O\&M Operations and Maintenance

PA Preliminary Assessment

PCB polychlorinated biphenyl

PIC pressurized ion chamber

PMS portable monitoring station

QA quality assurance

RCRA Resource Conservation and Recovery Act

REECo Reynolds Electrical and Engineering Company 


\section{ABBREVIATIONS}

(Concluded)

RFI RCRA Facility Investigation

SARA Superfund Amendments and Reauthorization Act

SDWA Safe Drinking Water Act

SHPO State Historic Preservation Office

SNL Sandia National Laboratories

SNL/NM Sandia National Laboratories/New Mexico

SNL/NV Sandia National Laboratories/Nevada

SOP Standard Operating Procedure

SPCC Spill Prevention, Control, and Countermeasures

STAR Stability Array

TCLP toxicity characteristic leaching procedure

TECR Tonopah Electronic Combat Range

TFW Tactical Fighter Wing

TLD thermoluminescent dosimeter

TPH total petroleum hydrocarbon

TSCA Toxic Substances Control Act

TSDF treatment, storage, and disposal facility

TSP total suspended particulates

TTR Tonopah Test Range

USAF U.S. Air Force

USGS U.S. Geological Survey

UXO unexploded ordance

UST underground storage tank

VOC volatile organic compound 


\section{Approximate Conversion Factors For Selected Si (Metric) Units}

\begin{tabular}{|c|c|c|}
\hline H Multiply si (metric) unit ${ }^{\prime}$ & +ै।by & $\begin{array}{l}\text { Toobtaind } \\
\text { customary unit }\end{array}$ \\
\hline cubic meter $\left(\mathrm{m}^{3}\right)$ & 35 & cubic feet $\left(\mathrm{ft}^{3}\right)$ \\
\hline centimeter $(\mathrm{cm})$ & 0.39 & inch (in.) \\
\hline meter $(\mathrm{m})$ & 3.3 & feet (ft) \\
\hline kilometer $(\mathrm{km})$ & 0.62 & mile (mi) \\
\hline square kilometer $\left(\mathrm{km}^{2}\right)$ & $\overline{0.39}$ & square mile $\left(\mathrm{mi}^{2}\right)$ \\
\hline hectare (ha) & 2.5 & acre \\
\hline liter (L) & $\overline{0.26}$ & gallon (gal) \\
\hline gram (g) & 0.035 & ounce (oz) \\
\hline kilogram (kg) & 2.2 & pound (lb) \\
\hline microgram per gram $(\mu \mathrm{g} / \mathrm{g})$ & 1 & part per million (ppm) \\
\hline milligram per liter (mg/L) & 1 & part per million (ppm) \\
\hline Celsius $\left({ }^{\circ} \mathrm{C}\right)$ & $\circ \mathrm{F}=9 / 5^{\circ} \mathrm{C}+32$ & Fahrenheit ( $\left.{ }^{\circ} \mathrm{F}\right)$ \\
\hline
\end{tabular}




\subsection{EXECUTIVE SuMMARY}

\subsection{Assessment of Potential Dose To The Public}

T $\mathrm{n}$ 1995, no radionuclides were released from the Tonopah Test Range (TTR) from stacks, vents, or other point sources under the administration of Sandia National L Laboratories/Nevada (SNL/NV). Based on the types of test activities, such as air drops, gun firing, ground-launched rockets, air-launched rockets, and other explosive tests, the possibility exists that small amounts of material (as part of the test component) could be released to the air or ground because of unusual circumstances (failures) during testing. There were no such failures in 1995.

A large area of transuranic surface contamination located on TTR is a potential diffuse source of airborne radionuclides through the action of wind resuspension of soil particulates. The surface contamination is the result of plutonium dispersal tests performed at the three Clean Slate sites in 1963. A total of 0.39 curies per year (Ci/yr) of contaminated material was calculated to be resuspended from the three Clean Slate sites. The maximum exposed individual (MEI) was determined to be located at the TTR Airport Area. The effective dose equivalent (EDE) calculated to this location was 1.1 millirem per year (mrem/yr), or approximately 11 percent of the $10-\mathrm{mrem} / \mathrm{yr}$ dose limit specified by U.S. Department of Energy (DOE) orders and Title 40, Code of Federal Regulations, Part 61, Subpart H (40 CFR 61, Subpart H).

\subsection{OVerview of 1995 Surveillance Results}

\section{Environmental Permits}

There are several environmental permits in place at TTR: 13 air permits, 4 public water system permits, 7 beneficial use water permits, one NPDES permit for the sewage lagoon facility, and one EPA identification number for hazardous waste disposal tracking through approved hazardous waste disposal contractors. TTR was in full compliance with all SNL controlled permit requirements in 1995. DOE/NV currently holds 6 air quality permits for TTR. Air emissions in 1995 were in compliance with applicable permits. A National Emission Standards for Hazardous Air Pollutants (NESHAP) annual report was prepared for FY95 (SNL 1996). A NESHAP Monitoring Plan was submitted to the EPA and approved in 1995. The Monitoring Plan will be implemented in 1996. 


\subsubsection{SNL Soil Sampling}

Limited soil sampling was performed at TTR as part of the continuing environmental surveillance activities. Soil samples were collected from off-site, the site perimeter, the On-Base Housing Area, the 554th Range Squadron Operations and Maintenance (O\&M) Complex, the South Plume Area, the Range Operations Center and Compound, and various additional on-site locations. All samples were analyzed for: 20 standard metals, total uranium $\left(\mathrm{U}_{\mathrm{tot}}\right)$, and by gamma spectroscopy. Elevated concentrations of $U_{\text {tot }}$ and various stable metals were found at several sampled locations.

\subsubsection{SNL Air Monitoring}

Limited air monitoring was performed at TTR in 1995. Air monitoring samples were collected from three separate locations at TTR. Composite samples were analyzed for gross alpha, gross beta, isotopic plutonium, $U_{\text {tot }}$ and 20 metals, and by gamma spectroscopy. Air monitoring results did not indicate significantly elevated concentrations of radiological or nonradiological constituents.

\subsubsection{Wastewater Sampling Program}

Forty-eight hour composite wastewater samples were collected in the $3 \mathrm{rd}$ and 4th quarters of 1995. During 1995, the State of Nevada issued a new NPDES permit to the U.S. Air Force (USAF) for its facultative sewage lagoon. Wastewater from the SNL/NV complex at Area 3 discharges to the USAF Lagoon. The USAF is required to submit a quarterly Discharge Monitoring Report (DMR) to the State of Neyada. Resuits of SNL's quarterly sampling and flow monitoring of sewage discharged from the Area 3 compound must be provided to the USAF for inclusion in the DMR report as required under the conditions of the permit.

During the third quarter of 1995 quarterly wastewater sampling was implemented to support USAF NPDES reporting requirements for the sewage lagoon.

\subsubsection{Drinking Water Sampling Program}

Drinking water for the SNL/NV operations at TTR is provided by a well permitted by the State of Nevada in compliance with Public Water Supply Standards. Compliance activities included bacteriological sampling and chlorination testing of the drinking water system in accordance with the Tonopah Test Range Site Sampling Plan (DOE 1990). Nitrate and Nitrate levels were analyzed for in the Well 6 drinking water, and results were submitted to the State of Nevada. 


\subsubsection{Hazardous Waste Program}

TTR is classified as a small quantity generator of hazardous waste. Three hazardous waste shipments were made in 1995. Standard operating procedures (SOPs) have been formalized to ensure compliance with the Resource Conservation and Recovery Act (RCRA). In calendar year 1995, 1585 kilograms $(\mathrm{kg})$ of hazardous waste and $4727 \mathrm{~kg}$ of regulated non-RCRA waste were disposed of through a permitted off-site treatment, storage, and disposal facility (TSDF), and a total of $4077 \mathrm{~kg}$ of hazardous or regulated material was sent to off-site recycling facilities.

In 1995, samples were collected and analyzed from all waste accumulation areas for justification of hazardous waste or non-RCRA waste status.

\section{Waste Minimization}

An informal waste minimization program is practiced at TTR. Antifreeze and Freon continue to be recycled with equipment procured in 1994 . A total of $4077 \mathrm{~kg}$ of material was shipped off-site for energy recovery or recycling in 1995 . Only $1585 \mathrm{~kg}$ of hazardous waste were shipped off-site for disposal in 1995 compared with $5615 \mathrm{~kg}$ in 1994. Approximately 58 boxes of usable fluorescent tubes were sent to SNL/NM for reapplication. Automotive batteries (102 ea.) were returned to the distributor for recycling and core charge recovery.

\section{Training}

Thirteen O\&M contractor personnel completed 40 hours (hr) of Hazardous Waste Operations Training or have attended the 8-hr refresher training in order to maintain their current certification. Many participated or assisted in extensive environmental cleanup/restoration efforts at TTR in 1995 (Section 4.3).

\section{Underground Storage Tanks (USTs)}

Total petroleum hydrocarbon (TPH) samples were collected from approximately 600 cubic yards $\left(\mathrm{yd}^{3}\right)$ of petroleum contaminated soil (UST removal remediation effort). Action was taken to procure funding for bioremediation of the soil scheduled for the spring of 1996.

Closure Notices were received from the State of Nevada for UST \#5 located near Building (Bldg.) 03-53 and for a tank that did not exist but was reported near Bldg. 0357. 


\section{Closure Plans}

Two closure plans were submitted to the State of Nevada Environment Department: (1) an In-situ Closure Plan for the diesel spill location at the generator building in Area 9 and (2) the UST excavation/removal location at Area 3 (four 10,000-gallon (gal) tanks).

\subsection{Overview of Compliance Status}

\section{National Environmental Policy Act (NEPA)}

At TTR, NEPA compliance is a joint effort between SNL, DOE/NV, and the Desert Research Institute (DRI). In 1995, a categorical exclusion was applied for by Bechtel and granted by DOE/NV to install solar powered air monitoring stations at Bunker 2 . This monitoring equipment is intended to monitor resuspension of material from the Clean Slate sites.

DRI accomplished one cultural resource survey for SNL operations near Bill's Hill.

\section{Reportable Spills}

There were no reportable spills in 1995 caused by DOE or SNL activities. The USAF had one reportable oil spill on DOE controlled property near Mellan Air Strip. The spill was caused by leaking smoke generators.

\section{Environmental Occurrences}

There were no environmental occurrence reports in 1995 from SNL activities. However, the use of Zap Rocket Motors to flash an ordinance pit under remediation did result in a warning letter from the State of Nevada's Division of Environmental Protection, to Department of Energy, Nevada (DOE/NV) and Department of Energy, Kirtland Area Office (DOE/KAO). 


\subsection{INTRODUCTION}

s required in DOE Order 5400.1 (DOE 1988), this site environmental report has
been prepared for the TTR to summarize environmental data that characterize site
environmental management performance, confirm compliance with Federal, state, and local environmental standards and requirements, and highlight significant programs and efforts. This report represents a key component of the DOE's effort to keep the public informed about environmental conditions at DOE facilities that conduct significant environmental protection programs. The report contains summary information about the radiological and nonradiological conditions of the site environment and identifies trends with regard to effluent releases and environmental conditions.

\subsection{TTR HISTORY \& OPERATIONS}

SNL/NV operates TTR for DOE's nuclear ordnance programs. SNL operations at TTR in Nevada date from 1957, when TTR came into limited use after similar facilities at the Salton Sea Test Base in California and at Yucca Flat on Nevada Test Site (NTS) became inadequate.

TTR was originally designed and equipped to gather raw data on aircraft-delivered inert test vehicles under U.S. Atomic Energy Commission (AEC) cognizance and was used as a bombing range during World War II. Over the years, the facilities and capabilities at TTR have been expanded to accommodate tests related to the AEC (later, DOE) weapons development program. Tests conducted vary from simple tests of hardware components and systems needing only limited support to rocket launches and air drops of test vehicles requiring full range support.

The seven categories of test activities at TTR are: (1) air drops, (2) gun firings, (3) ground-launched rockets, (4) air-launched rockets, (5) explosive effects, (6) static rocket tests, and (7) earth penetrator tests. Most of these activities require a remote range for safety and security reasons. The $1994 \mathrm{SNL} / \mathrm{NV}$ and USAF activities included flying sorties, rocket/missile flights, and air drops.

\subsection{LOCATION \& POPULATION}

TTR is located approximately 140 miles (mi) northwest of Las Vegas, NV and covers 624 square miles ( $\mathrm{mi}^{2}$ ) within the boundaries of the Nellis Air Force Base (NAFB) Range Complex (Figure 2-1). It is bordered on three sides by the NAFB Range Complex and on the north by sparsely populated public lands administered by the Bureau of Land Management (BLM) and the U.S. Forest Service. The nearest population centers are Goldfield, population 659, located approximately $25 \mathrm{mi}$ west of TTR, and Tonopah, 


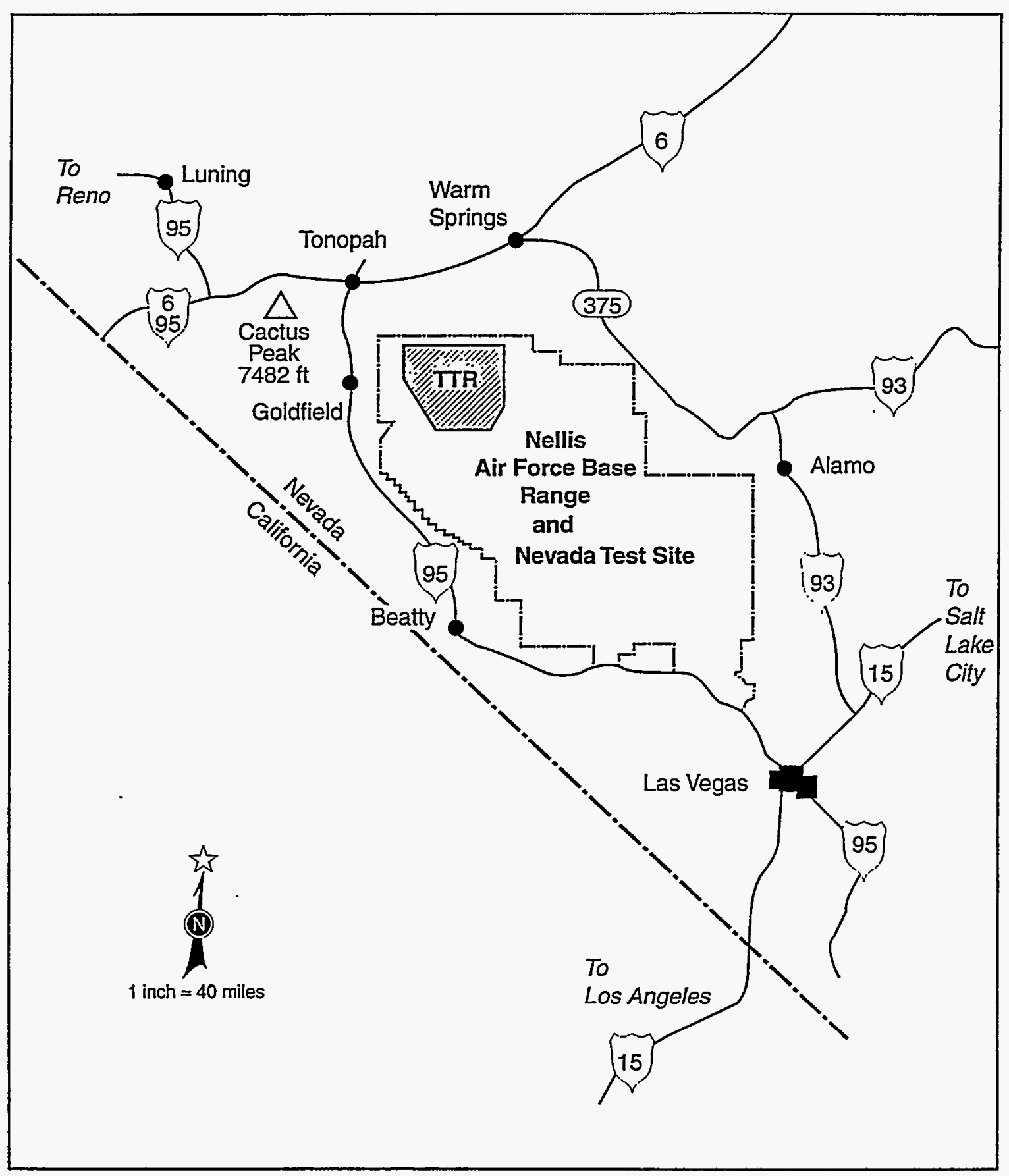

Figure 2-1. Location of Tonopah Test Range, Nevada. 
population 4400, located 30 mi northwest of TTR (DOC 1991). The total population within a 50-mi region around TTR is 9299 . This number includes a population of 1000 which accounts for base housing and on-site and contractor (non-SNL) personnel.

\subsection{Geology, Climatology, \& Biology}

TTR is situated in a high-desert environment and consists of broad valleys bordered by north/south-trending mountain ranges in the western part of the Basin-and-Range geophysical province. TTR lies northeast of a zone of transcurrent faulting and shear, termed the Walker Lane, and the Las Vegas Valley shear zone to the southeast (Sinnock 1982). Cactus Flat, which constitutes the basic working area of TTR, is a basin surrounded by the Cactus Range. The Cactus Range is a northwest-trending, raised structural block, one of at least five that lie along the Las Vegas Valley-Walker Lane lineaments (ERDA 1975).

All the working areas of TTR lie within an area of approximately $400 \mathrm{mi}^{2}$. The streams in and near TTR are intermittent and end in closed basins. There are three springs within TTR: Cactus, Antelope, and Silverbow Springs. Water from these springs does not travel far; it disappears rapidly through evaporation and infiltration, and its effect on the landscape is purely local. Water used in TTR facilities comes from wells tapping underlying groundwater in alluvium derived from the surrounding mountains. Well depth to groundwater varies from $21 \mathrm{ft}$ (Antelope Mine) to $454 \mathrm{ft}$ (EH2). The depth to groundwater at Area 9 is approximately $131 \mathrm{ft}$, and depth to groundwater at Area 3 is 361 $\mathrm{ft}$ to $394 \mathrm{ft}$ (provided by the U.S. Geological Survey [USGS]).

The climate is mild and usually dry, but, as is typical of high deserts, it is subject to large diurnal and seasonal changes in temperature, from a record high of 102 degrees Fahrenheit ( ${ }^{\circ} \mathrm{F}$ ) to a record low of $-24^{\circ} \mathrm{F}$ (Schaeffer 1982). Clear, sunny days with light to moderate winds are usual. Average rainfall is approximately 5 inches (in.) per year in the valley, with most precipitation occurring in August (ERDA 1975; Schaeffer 1982). Winds are mostly from the west-northwest and from the south-southeast. Dust storms are common in the spring, and dust devils are common in the summer. 
Because of the temperature extremes and arid conditions at TTR, the valley in which most TTR activities occur is sparsely covered with range grasses and low shrubs (ERDA 1975; EG\&G 1979a). Joshua trees grow in the foothills and juniper trees grow in the foothills and mountains. Hundreds of wild horses graze freely throughout TTR and their exposure to TTR activities has apparently had little effect on their population and grazing habits.

Because of the temperature extremes and arid conditions at TTR, the valley in which most TTR activities occur is sparsely covered with range grasses and low shrubs (ERDA 1975; EG\&G 1979a). Joshua trees grow in the foothills and juniper trees grow in the foothills and mountains. Hundreds of wild horses graze freely throughout TTR and their exposure to TTR activities has apparently had little effect on their population and grazing habits.

\subsection{Project Roller Coaster Tests}

Project Roller Coaster included a series of four plutonium $(\mathrm{Pu})$ dispersal tests (three at TTR and one at the NAFB Gunnery Range) executed in May and June of 1963. The locations of the three Project Roller Coaster tests at TTR are referred to as Clean Slates 1, 2, and 3; the fourth site is referred to as the Double Tracks site (Figure 2-2). Table 2-1 summarizes test information related to the four Project Roller Coaster sites. Through agreement with DOE's Albuquerque Operations Office (DOE/AL), DOE's Nevada Operations Office (DOE/NV) has the Environmental Restoration (ER) responsibilities for the Clean Slate sites; SNL maintains the environmental surveillance responsibilities.

Table 2-1. Project Roller Coaster test information.

\begin{tabular}{|c|c|c|c|c|}
\hline Test & Gleanslatel & efean slate 2 & Oleanslate 3 & Double tracks \\
\hline Date: & May 25,1963 & May 31,1963 & June 9, 1963 & May 15,1963 \\
\hline Location: & Tonopah Test & TTR & TTR & Nellis Air \\
\hline $\begin{array}{l}\text { Plutonium } \\
\text { Inventory } \\
\text { (curies [Ci]): }\end{array}$ & $5.2 \pm 1.6$ & $29 \pm 6.2$ & $30 \pm 4.9$ & $5.0 \pm 1.4$ \\
\hline
\end{tabular}

Source: Annual Site Environmental Report provided by the U.S. Department of Energy Nevada Operations Office. 


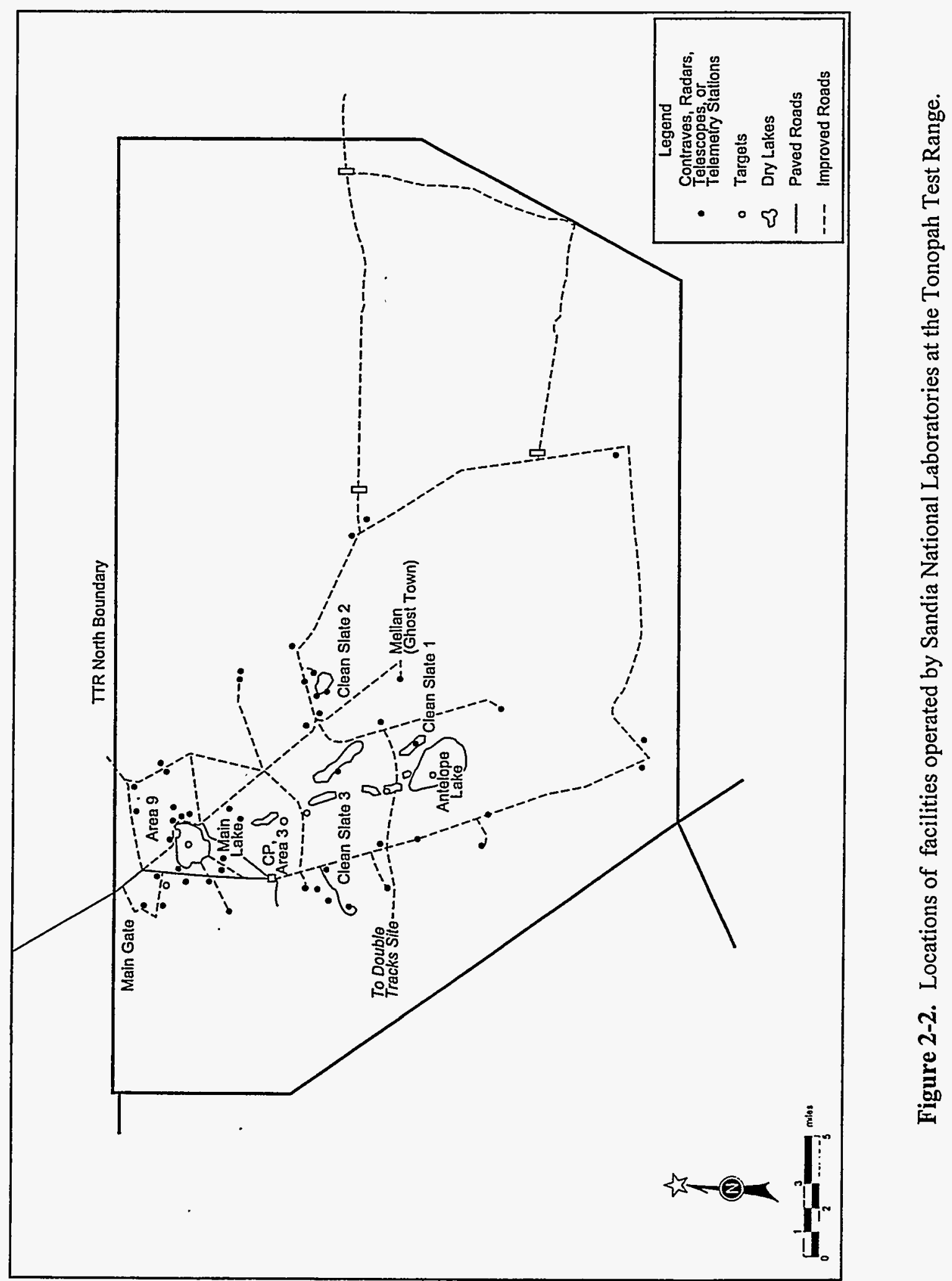


The initial cleanup of each Clean Slate site was conducted shortly after each test and consisted of blading the test-related debris into a hole at test ground-zero. Each hole was then backfilled with dirt and a fence was erected around each test area. The fenced boundaries were set at approximately 1000 micrograms plutonium per square meter $\left(\mu \mathrm{g} / \mathrm{m}^{2}\right)$ as determined using hand-held survey meters (Rarrick 1993). In 1973, additional outer fences were built, set at 40 picocuries plutonium per gram $(\mathrm{pCi} / \mathrm{g})$ of soil as determined using hand-held survey meters (Rarrick 1993). This survey was conducted with a field instrument for the detection of low-energy radiation (FIDLER) using 61meter (m) grids. Surface soil has been sampled intermittently at the Clean Slate sites. An aerial radiologic survey was performed by Edgerton, Germeshausen \& Grier Corporation (EG\&G) for the Nevada Applied Ecology Group (NAEG) in 1977 using the 1973 grid. The objective of the aerial survey was to determine the surficial distribution of $\mathrm{Pu}$ and other transuranic elements dispersed during the Project Roller Coaster tests. The aerial surveys were undertaken to supplement the FIDLER and previous soil sample measurements of Americium-241 (Am-241), a Plutonium-241 (Pu-241) decay product present in the $\mathrm{Pu}$ of the test device). Radiation isopleths showing soil activity caused by Am-241, Plutonium-239 (Pu-239), and Plutonium-240 (Pu-240) were drawn for each area (EG\&G 1979b). This survey showed the extent of the transuranic contamination, both inside and outside the two control fences, of the Clean Slate sites. The test areas are examined visually twice a year to determine whether any fence repairs are required. When discovered, horses that may have wandered inside the fenced areas are promptly removed. 


\subsection{COMPLIANCE SUMMARY}

andia National Laboratories (SNL) strives to operate in full compliance with environmental and other requirements established by federal and state regulations, executive orders, and U.S. Department of Energy (DOE) orders. The following sections summarize the status of the Tonopah Test Range (TTR) in complying with major environmental statutes.

\subsection{EnVIRONMENTAL Restoration Activities}

In late 1992 and early 1993 an agreement was reached between DOE Headquarters. (DOE/HQ), DOE/KAO, and DOE/NV on the management of the TTR Environmental Restoration (ER) activities. Since ER activities at TTR would be the first performed in the State of Nevada by the DOE, it was felt that one field office should develop the remediation and closure plans for all sites in Nevada. It was agreed that DOE/NV will manage all of the DOE/KAO and DOE/NV ER activities at TTR. ER activities in fiscal year 1995 (FY95) were conducted by the DOE/NV Environmental Restoration Project through an interim agreement with DOE/AL and DOE/KAO. This agreement provided funding to the ER Project with DOE/KAO oversight.

Presently, ER sites at the TTR are included in the draft Federal Facilities Agreement and Consent Order (FFACO), between the State of Nevada and the DOE. A summary of these sites can be found in Section 4.3 and Table 4-4 of this report. The list of sites has been modified for consistency with NDEP requirements and grouped into Corrective Action Units (CAUs) and listed by Corrective Action Site (CAS) numbers. Each of these CAUs is listed in Appendices II (inactive CAUs) and III (active CAUs) of the FFACO and presented at Table $X$.

Two underground storage tank sites (CAS Nos. 03-02-001-03053 and 03-02-003-03-57) were approved for closure by the NDEP in CY95 and have been removed from the ER list. These sites will remain in Appendix IV (closed sites) of the FFACO. 


\subsection{Compliance Regulations}

\subsubsection{Comprehensive Environmental Response, Compensation and Liability Act (CERCLA) \& Super-fund Amendments and Reauthorization Act (SARA)}

As required under CERCLA/SARA, Section 120(d), a Preliminary Assessment (PA) was submitted for all facilities listed on the Federal Agency Hazardous Waste Compliance docket in 1988.

TTR is not on the National Priorities List, an ordered ranking of top priority CERCLA sites. A CERCLA site is placed on this list if the site is above a certain threshold level established by the U.S. Environmental Protection Agency (EPA).

\subsubsection{Resource Conservation and Recovery Act (RCRA)}

TTR is permitted as a "less than 180 day storage area" small quantity generator due to a reduction in operations during 1994. A small quantity generator accumulates more than $100 \mathrm{~kg}$ but less than $1000 \mathrm{~kg}$ of hazardous waste per month. Before 180 days of storage (270 days if the TSDF is located more than $200 \mathrm{mi}$ from the generators location), the waste must be shipped to an EPA permitted TSDF.

Hazardous waste shipments are scheduled to occur two to three times per year. During 1995 , there were three hazardous waste shipments. (Safety Kleen shipments were not included in this count.

Hazardous chemical wastes are collected, packaged, and shipped off-site to an EPApermitted treatment, storage, and disposal facility (TSDF). Standard Operating Procedure (SOPs) have been written to ensure continued compliance with RCRA.

Currently, one Class II sanitary landfill is in operation at TTR. This unit is operated by the USAF O\&M contractor and cooperatively used by all organizations on TTR. SNL/NV removed five USTs from TTR in 1994. Currently, there are no USTs managed by SNL/NV on TTR. The Environmental Restoration Group is investigating some potentially undocumented/historical UST sites during their activities. Additional information should be available in 1996.

\subsubsection{Clean Air Act (CAA)}

TTR is regulated by the CAA and State of Nevada air quality regulations, published in the Nevada Revised Statutes, Title 40, Public Health and Safety, Chapter 445 (Appendix 
A, Table A-1). The State of Nevada issued CAA permits for the following activities:

- Aboveground storage tanks-USAF

- Concrete batch plants-DOE/NV

- Vapor extraction unit-USAF

- Incinerator-USAF

- Disturbance land use greater than 5 acres-DOE/NV

- Crusher/screen-DOE/NV

Air emissions in 1994 were in compliance with applicable permits. A NESHAP annual report was prepared for CY94 (SNL 1995a).

\subsubsection{Clean Water Act (CWA)}

TTR is regulated by the CWA and State of Nevada water pollution and sanitary waste systems regulations (Appendix A, Table A-1). The State does not have a permitting process for septic tanks.

The sewage systems in Area 3, (the main industrial area) is connected to the USAF facultative sewage lagoon facility. Composite samples (over $48 \mathrm{hr}$ ) are obtained on a quarterly basis by SNL/NV, as required in wastewater permit NEV20001. The minimum reportable parameters are flow, total petroleum hydrocarbon (TPH), volatile organic compound (VOC), and eight RCRA metals. Results must be reported to the USAF for inclusion in their DMR to the State of Nevada at the end of each quarter.

The 13 septic tanks that served TA-3 until 1990, (when the consolidated sewage system was installed), will require further testing to ensure that no hazardous constituents are present before disposing of the waste and closing the tanks in conformance with State of Nevada regulations.

The remote locations on TTR are serviced by septic tank systems. These septic systems are maintained by the TTR facilities group.

\subsubsection{Safe Drinking Water Act (SDWA)}

TTR is regulated by the SDWA and State of Nevada public water supply and public water systems regulations. Drinking water for SNL/NV operations at TTR is provided by a well permitted by the State of Nevada in compliance with the public water supply standards. Compliance activities include bacteriological sampling of the drinking water system in accordance with the Tonopah Test Range Site Sampling Plan (DOE 1990). A state-certified water distribution operator is employed on the support contractor staff in fulfillment of state requirements for a certified water distribution operator for community systems. The Water Conservation Plan for the TTR complies with State Water Resources 
Division regulations requiring a water conservation plan for permitted water systems and major water users in Nevada (DOE 1992).

\subsubsection{Toxic Substances Control Act (TSCA)}

All transformers on TTR owned by DOE/KAO were sampled and analyzed in 1993 (IT 1993) for polychlorinated biphenyls (PCBs). This information was consolidated into a SNL/New Mexico (SNL/NM) database and into the SNL/NV inventory database. None of the samples contained more than 50 parts per billion of PCBs.

\subsubsection{Federal Insecticide, Fungicide, and Rodenticide Act (FIFRA)}

Only EPA-registered pesticides are applied at SNL facilities. These pesticides are applied by an EPA-certified applicator. SNL retains records of the quantities and types of pesticides that are used as well as Material Safety Data Sheets (MSDSs) for each pesticide.

\subsubsection{Endangered Species Act (ESA)}

The DOE must comply with the ESA when planning Federal actions or major construction activities. The key provision of the ESA for federal activities is Section 7, "Consultation," which states that Federal agencies must consult with the U.S. Fish and Wildlife Service to ensure that any agency actions are "not likely to jeopardize the continued existence of any endangered species or threatened species or result in the destruction or adverse modification of habitat of such species." There has not been a recent Environmental Assessment (EA) to detail the current situation in regard to sensitive species, though some of these species are known to occur in the area (ERDA 1975; EG\&G 1979a). SNL assists the DOE in complying with the ESA at TTR.

\subsubsection{Cultural Resources Acts}

TTR holds responsibilities for cultural resources management, including those responsibilities applicable under the National Historic Preservation Act (NHPA), the Archaeological Resources Protection Act (ARPA), and the American Indian Religious Freedom Act (AIRFA). SNL integrates cultural resources management into the National Environmental Policy Act (NEPA) program. DOE requires NEPA review for all DOE actions potentially affecting the environment; thus, even actions that may be categorically excluded are reviewed for impacts on cultural resources, among other things. (See Section 4.4 for further information on NEPA activities.) 


\subsubsection{Executive Orders}

Executive Order 11988, Floodplain Management, and Executive Order 11990, Protection of Wetlands, require evaluation of the potential effects of actions taken in floodplains and wetlands. There are no floodplains or wetlands at TTR.

\subsection{AuDITS}

The following Audits or visits by the State of Nevada or DOE officials occurred in 1995:

1/19/95 Hazardous Materials Spill Exercise/Evaluation by SNL/NM

2/28/95 State of Nevada Federal Facilities Division Environmental Restoration Site Evaluation: 5-Points, Rollercoaster, and Area 9 Landfills. Visited Area 3 UST removal site and Area 9 diesel spill location. Observed Bomblet $P$ it robotic unit operation.

3/13/95 Hazardous waste activities pre-state inspection audit, SNL Generator Interface Dept.

3/21/95 Nevada Dept. of Environmental Protection (NDEP) RCRA Audit. No significant findings, no report provided.

3/22/95 Post NDEP evaluation SNL, DOE/NV.

12/13-14/95 RCRA Audit, SNL Generator Interface Dept.

12/13-14/95 TSCA Audit (PCB), SNL Generator Interface Dept.

\subsection{CuRrent Issues \& Actions for TTR}

Ongoing self-assessments of compliance status continue to identify compliance issues. Resolution of these issues is coordinated with regulatory agencies to ensure that they are addressed. The following sections highlight the issues of concern at TTR:

\section{Septic Tanks/Sewage Line}

The facility group performed sampling of the septic tanks in FY90 using procedures that met Federal and state requirements. Since FY90, federal and state regulations imposed more stringent testing parameters, including the requirement for analytical testing using the toxicity characteristic leaching procedure (TCLP). Septic tank sampling was also 
performed in 1993. Inactive septic tanks will be sampled again during future ER activities.

\section{Underground Storage Tanks}

The last known USTs that DOE or SNL are responsible for on the TTR site were removed in August 1994. Four 10,000-gallon, fiberglass tanks (two diesel and two gasoline), that provided fuel to the former gas station in Area 3; and one 1,000-gallon steel tank (diesel), for a generator in Area 9, were removed by a Certified Environmental Manager (CEM) and a State of Nevada licensed contracting firm. Certificates of destruction for these five tanks are on file.

\subsection{Environmental Permits}

As part of the DOE complex, the SNL-operated TTR is committed to full compliance with all applicable environmental laws and regulations and to protection of the environment. TTR is regulated by Federal laws and State of Nevada regulations for the applicable activities. (See Table A-1 in Appendix A for the state regulations and the corresponding activities.)

The permit application and registration of SNL/NV activities at TTR are administered by Kirk-Mayer, Inc. (KMI Services). There are a total of 14 air permits (eight permits owned by the USAF, five by DOE/NV, and one by DOE/KAO), four public water system permits (one owned by DOE/KAO, three by the USAF), one NPDES permit for the sewage lagoon facility (owned by the USAF), and one EPA identification number for chemical hazardous waste on TTR (owned by DOE/KAO) (Table 3-1). The State of Nevada has not made a determination on permitting for the storm water program. TTR has no waters of the United States within its boundaries; thus, following best management practices, SNL/NV activities on TTR may be permitted by SNL itself. Table A-2 of Appendix A includes detailed permit listings with expiration dates, issuing agencies, and responsible parties. TTR was in full compliance with all permit requirements for 1995 . 
Table 3-1. Summary of Permit ownership at the TTR.

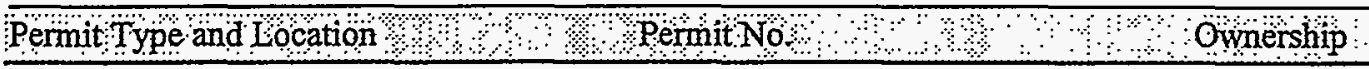

Air Quality

Petro Storage

Petro Storage

Petro Storage

Petro Storage

Petro Storage

Petro Storage

Batch Plant (Ross)

Batch Plant (Johnson)

Crushers

Screens

Incinerator

Surface Disturbance

Vapor Extraction

Public Water System

Mancamp

Industrial Area

Sandia Compound

Tonopah Electronic

Combat Range (TECR)

Compound

National Pollutant Discharge

Elimination System (NPDES)

Sewage System

Hazardous Waste

SNL/EPA Generator ID No.

Beneficial Use Water Permits

Well EH-1

Well EH-2

Well 1-A

Well EH-7

Well BLM

Well 3 B

Well $3 \mathrm{~A}$

Permit to construct.
2456,2457

2455

2450

2844

3172

NY-4068-12C

NY-5001-12NC

NY-3014-12NC

NY-5002-12NC

NEV20001

NV1890011991

50166

50169

50168

53885

56916

58149

58150
USAF

USAF

Activated/DOE/KAO

U.S. Air Force (USAF)

USAF

USAF

USAF

USAF

USAF

DOE/NV

DOENV

DOE/NV

DOE/NV

USAF

DOE/KAO

USAF

USAF

USAF

DOE/Kirtland Area

Office (DOE/KAO)$$
\text { DOERAO }
$$

DOE/NV for USAF Well DOE/NV for USAF Well DOE/NV for USAF Well DOE/NV for USAF Well DOE/NV for USAF Well DOEANV for USAF Well DOE/NV for USAF Well 
This page intentionally blank. 


\subsection{OTHER ENVIRONMENTAL PROgRAMS}

I

$t$ is the policy of the DOE and SNL to conduct operations in an environmentally responsible manner and in compliance with applicable environmental standards. SNL maintains a variety of environmental programs to implement these laws and regulations and protect the quality of the environment. This chapter describes SNL activities conducted in 1995 at TTR to remediate sites contaminated in the past, to manage hazardous, radioactive, mixed, and other wastes, to comply with environmental protection requirements, and to respond to releases and environmental incidents. Other environmental programs at TTR include terrestrial surveillance, air quality surveillance, and wastewater monitoring. These environmental surveillance programs are addressed in Chapter 5.

\subsection{Spill Prevention Control \& Countermeasures Plan}

The Spill Prevention Control and Countermeasures (SPCC) Plan for TTR was completed by SNL in 1990 (SNL 1990), updated in June 1994 (SNL 1994) and completely implemented in 1995. This plan was prepared in accordance with 40 CFR 112, Oil Pollution Prevention. The SPCC Plan for SNL/NV at TTR documents 29 locations for secondary containment upgrades, including transformers, aboveground storage tanks, and three bulk storage areas. Construction of the secondary containment areas was completed in FY93. The SPCC plan was completely implemented in 1995.

\subsection{Waste Management Programs}

Waste management is the safe and effective management of active and standby facilities and the treatment, storage, and disposal of radioactive, hazardous, and mixed wastes. The following sections include summary descriptions of major waste management programs and activities at TTR.

\subsubsection{Chemical \& Hazardous Waste Management}

Chemical wastes generated by SNL/NV activities at TTR during calendar year 1995 (CY95) were managed by KMI Services, the facilities support contractor.

In CY95, $1585 \mathrm{~kg}$ of RCRA regulated hazardous waste and $4727 \mathrm{~kg}$ of regulated nonRCRA waste were shipped off the TTR for disposal at a permitted TSDF. Table 4-1 shows a breakdown of the waste categories and quantities for RCRA regulated waste $(1585 \mathrm{~kg})$. Table 4-2 lists regulated non-RCRA waste and quantities shipped off-site for treatment and disposal $(4727 \mathrm{~kg}$ ). Table 4-3 lists waste transported off-site for recycling or alternative fuel use $(4077 \mathrm{~kg})$. 
Table 4-1. All RCRA regulated chemical and hazardous waste shipped off-site in 1995 for disposal.

\begin{tabular}{|c|c|c|}
\hline Sutpling Name & Waste Codes & $\begin{array}{l}\text { Weight: } \\
\text { (kilograms) }\end{array}$ \\
\hline $\begin{array}{l}\text { Waste flammable liquids, NOS, } \\
\text { petroleum naphtha, petroleum distillates }\end{array}$ & D001 & 194 \\
\hline Waste diethyl ether & D001 & 48 \\
\hline Waste aerosols flammable & D001 & 236 \\
\hline $\begin{array}{l}\text { Hazardous waste solid NOS rags with } \\
\text { methylene chloride }\end{array}$ & F002 & 248 \\
\hline $\begin{array}{l}\text { Hazardous waste solid NOS sodium } \\
\text { vapor lamps }\end{array}$ & D005 & 17 \\
\hline $\begin{array}{l}\text { Waste environmentally hazardous } \\
\text { substances, solid, NOS, nicads }\end{array}$ & D006 & 38 \\
\hline Hazardous waste solid NOS Lead & D008 & 4 \\
\hline $\begin{array}{l}\text { Waste, battery wet filled with acid, } \\
\text { sulfuric acid, lead }\end{array}$ & D002, D008 & 217 \\
\hline $\begin{array}{l}\text { Waste environmentally hazardous } \\
\text { substances, solid, NOS oily rags } \\
\text { acetone mek }\end{array}$ & D035, F003, F005 & 81 \\
\hline $\begin{array}{l}\text { Waste paint related material, } \\
\text { lacquer thinner, mek }\end{array}$ & D001, D035, F003, F005 & 384 \\
\hline $\begin{array}{l}\text { Hazardous waste liquid NOS oil } \\
\text { with selenium, endrin }\end{array}$ & $\begin{array}{l}\text { D018, D019, D010, D012 } \\
\text { D023, D020, D031, D032 } \\
\text { D033, D034, D013, D036 } \\
\text { D027, D028, D037, D038 } \\
\text { D015, D040, D041, D042 } \\
\text { D043, D025 }\end{array}$ & 118 \\
\hline Total & & 1,585 \\
\hline
\end{tabular}


Table 4-2. Regulated waste, other than RCRA Waste, shipped off-site for treatment and disposal.

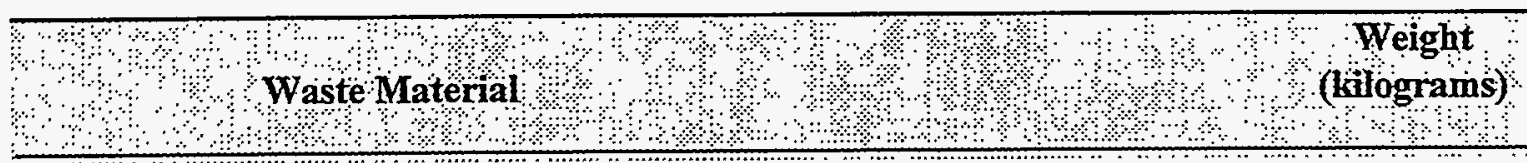

$\begin{array}{ll}\text { Waste antifreeze (non-recyclable) } & 563\end{array}$

Sealed capacitors possible PCB $\quad 518$

$\begin{array}{lr}\text { Batteries non-regulated Alakaline } & 489\end{array}$

Petroleum contaminated soil, rags, filters, etc. $\quad 2,772$

$\begin{array}{ll}\text { Expired/outdated materials } & 325\end{array}$

Possible asbestos containing material $\quad-60$

$\begin{array}{lr}\text { Total } & 4,727\end{array}$ 
Table 4-3. Hazardous and regulated non-RCRA waste shipped off-site in 1995 for recycling.

W

Used oil

Contaminated gasoline

94

Safety Kleen solvent (petroleum maphtha)

Safety Kleen immersion cleaner (monoethanolamine)

172

Fluorescent light bulbs (mercury recovery) 398

Mercury containing equipment (thermostats, etc.)

Sodium light bulbs

Automotive batteries

102 ea.

Total

4,077

\subsubsection{Waste Minimization Program}

An informal waste minimization program is practiced at TTR. TTR is committed to achieving significant reductions in the amount of both hazardous and non-RCRA wastes. In 1994, antifreeze recycling and Freon recovery units were procured. Waste minimization includes recycling and recovery of the following materials:

- Solvents

- Fuels

- Oil

- Antifreeze (on-site recycling unit)

- Lead acid battery

- Freon recovery (on-site recovery unit)

- Fluorescent and sodium bulb

- Mercury containing component 


\subsection{Environmental Restoration Project}

The ER Project is a phased DOE program to identify, assess, and correct past spill, release, or disposal sites at all owned and operated sites including the SNL-operated TTR. The method parallels the EPA's CERCLA program to identify, characterize, and clean up inactive waste sites and past release sites. Table 4-4 summarizes the ER Project sites at TTR planned for investigation by SNL/NV. DOE/NV is responsible for the three Clean Slate sites.

The waste listed in Table 4-2 was shipped to the following facilities for disposal and/or recycling:

- Ensco West (Wilmington, CA)

- Safety Kleen Corp. (Las Vegas, NV)

- Sales Co (Phoenix, AZ)

- Romic Environmental Technologies (Chandler, AZ)

The initial identification, description, and listing of the ER waste sites was derived from the Preliminary Assessment (PA) and the Federal Facility Preliminary Assessment Review. In 1993, IT Corporation obtained additional information related to these previously identified ER sites and identified new ER sites through the ER sites inventory process, geophysical surveys, and aerial radiological and multispectral surveys. These newly identified sites were included and listed based upon joint efforts of the DOE/NV and SNL in the form of interviews with former site workers, archive reviews, and site visits.

\section{ER Activities at TTR in 1995}

A Voluntary Corrective Action work plan (DOE 1995) was finalized and on February 3, 1995, DOE/NV received a permit exclusion for corrective action at the Tonopah Test Range from the Nevada Division of Environmental Protection (NDEP). The implementation of the corrective action work plan involved the removal and processing of unexploded ordnance (UXO) and other debris at five Corrective Action Sites (CAS). These sites are:

- Bomblet Pit, CAS No. TA-55-001-TA-B2

- Five Points Landfill, CAS No. TA-19-001-05-PT

- Area 9 Landfill, CAS No. 09-10-001-09-52 
- Area 9 Construction Debris Area, CAS No. 09-08-001-TA-09

- Roller Coaster Sewage Lagoons, CAS No. TA-03-001-TA-RC

- These 5 sites contained construction debris, UXO, practice ordnance, scrap metal, and some items containing hydrocarbons, hazardous, or radioactive constituents. Items were identified, removed, and segregated on each site.

Table 4-4. Department of Energy Environmental Restoration Division Tonopah Test Range Corrective Action units and sites (Continues).

\begin{tabular}{|c|c|c|}
\hline 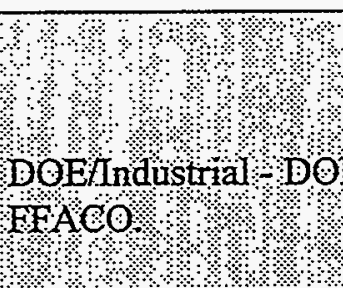 & 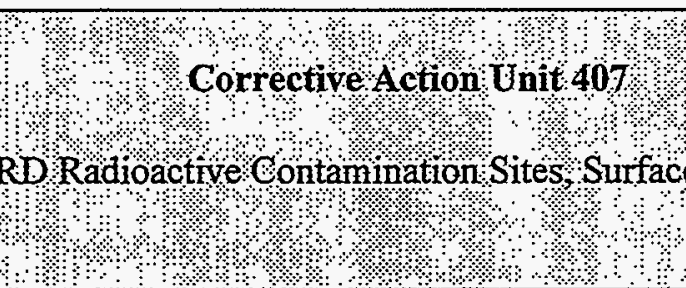 & arfoctonopat Test \\
\hline $\begin{array}{l}\text { Corrective Action } \\
\text { Site Number }\end{array}$ & Corrective Action Site Description & General Location \\
\hline TA-23-001-TARC & Roller Coaster Rad Safe Area & NW of Antelope Lake \\
\hline TA-39-001-TAGR & Cactus Spring Ranch, Soil Contam. & West of Target Areas \\
\hline TA-52-001-TANL & Rocket Propellant Burn Area & NEDS Lake \\
\hline TA-52-002-TAML & Depleted Uranium Impact Site & Main Lake \\
\hline TA-52-003-0960 & Depleted Uranium Artillery Round & South of Area 9 \\
\hline TA-52-004-TAAL & Metal Particle Dispersion Test & Antelope Lake \\
\hline TA-52-005-TAAL & Joint Test Assembly DU Sites & Antelope Lake \\
\hline $\begin{array}{l}\text { DOE/Industrial - DC } \\
\text { Tonopah, FFACO. }\end{array}$ & $\begin{array}{r}\text { Corrective Action Units } 400 \\
\text { Closed Ordnance Disposal Pits; Bomb }\end{array}$ & ve Points Landfill, \\
\hline $\begin{array}{l}\text { Corrective Action } \\
\text { Site Number }\end{array}$ & Corrective Action Site Description & General Location \\
\hline TA-19-001-05PT & Ordnance Disposal Pit & $\begin{array}{l}\text { Five Points } \\
\text { Intersection }\end{array}$ \\
\hline TA-55-001-TAB2 & Ordnance Disposal Pit & Bunker 2 Road \\
\hline
\end{tabular}


Table 4-4. Department of Energy Environmental Restoration Division Tonopah Test Range Corrective Action units and sites (Continued).

\begin{tabular}{|c|c|c|}
\hline DOERRD Olosed Und & Gorrective & 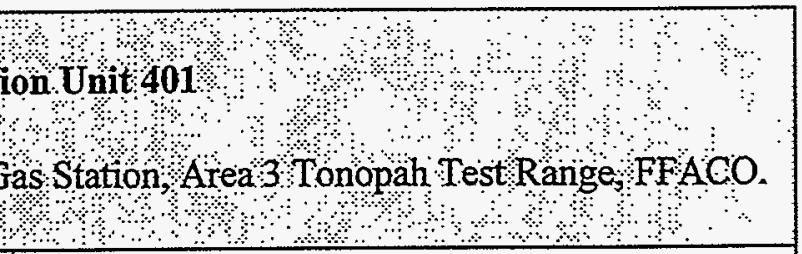 \\
\hline $\begin{array}{l}\text { Corrective Action } \\
\text { Site (CAS) Number }\end{array}$ & $\begin{array}{l}\text { Corrective Action } \\
\text { Site Description }\end{array}$ & General Loc \\
\hline $03-02-003-0357$ & $\begin{array}{l}\text { Underground Storage } \\
\text { Tank, Gas }\end{array}$ & First Gas Station, Area 3 \\
\hline 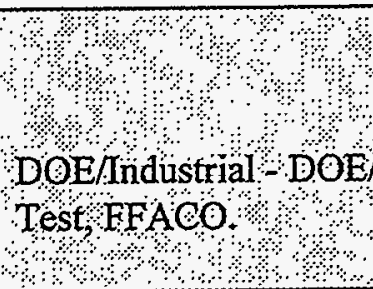 & 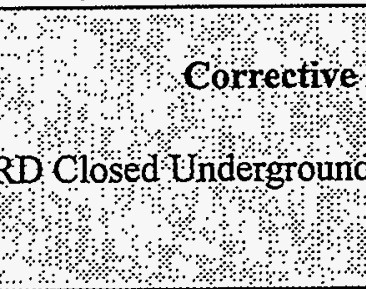 & 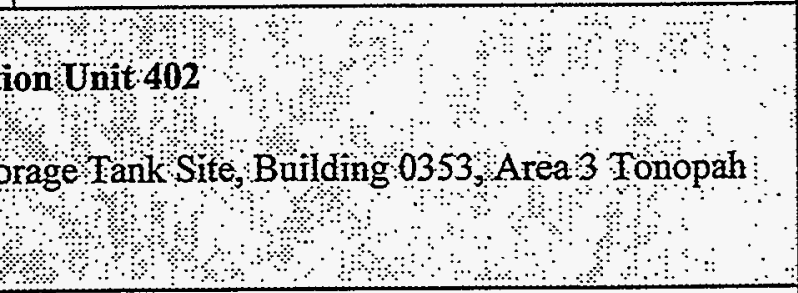 \\
\hline $\begin{array}{c}\text { Corrective Action } \\
\text { Site (CAS) Number }\end{array}$ & $\begin{array}{l}\text { Corrective Action } \\
\text { Site Description }\end{array}$ & General Lo \\
\hline $03-02-001-0353$ & $\begin{array}{l}\text { Underground Storage } \\
\text { Tank, Diesel }\end{array}$ & Building 0353 \\
\hline 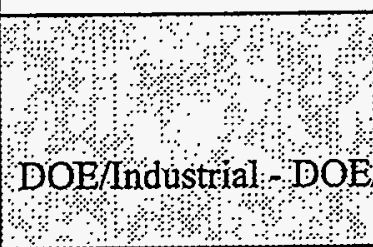 & 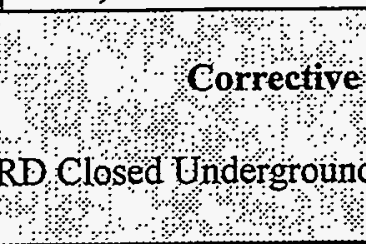 & 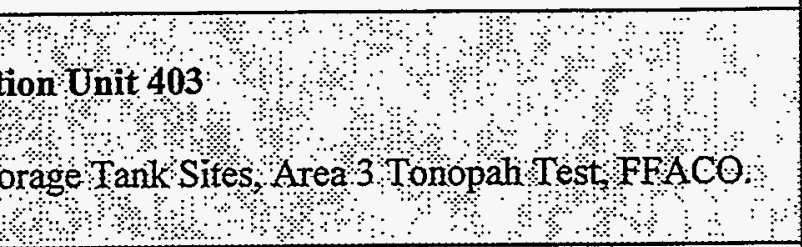 \\
\hline $\begin{array}{l}\text { Corrective Action } \\
\text { Site (CAS) Number }\end{array}$ & $\begin{array}{l}\text { Corrective Action } \\
\text { Site Description }\end{array}$ & General Loc \\
\hline $03-02-004-0360$ & $\begin{array}{l}\text { Underground Storage } \\
\text { Tanks }\end{array}$ & tation \\
\hline
\end{tabular}


Table 4-4. Department of Energy Environmental Restoration Division Tonopah Test Range Corrective Action units and sites (Concluded).

\begin{tabular}{|c|c|c|}
\hline 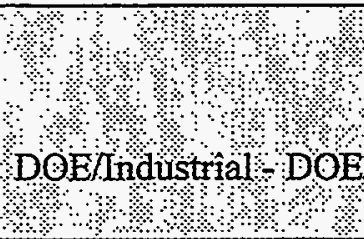 & 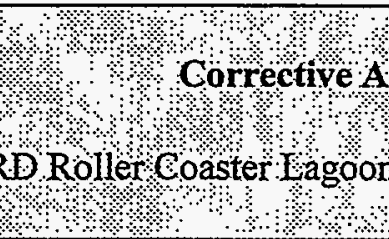 & 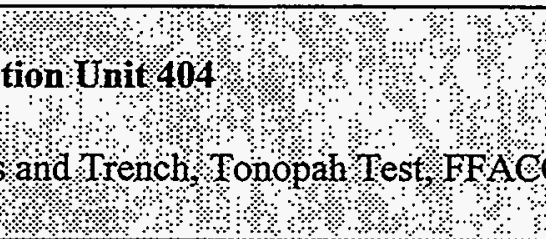 \\
\hline $\begin{array}{l}\text { Corrective Action } \\
\text { Site (CAS) Number }\end{array}$ & $\begin{array}{l}\text { Corrective Action } \\
\text { Site Description }\end{array}$ & General Location \\
\hline TA-03-001-TARC & Roller Coaster Lagoons & NW of Antelope Lake \\
\hline TA-03-001-TARC & $\begin{array}{l}\text { Roller Coaster N. } \\
\text { Disposal Trench }\end{array}$ & NW of Antelope Lake \\
\hline कै. & 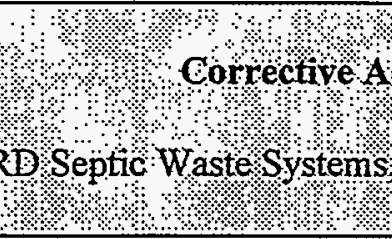 & 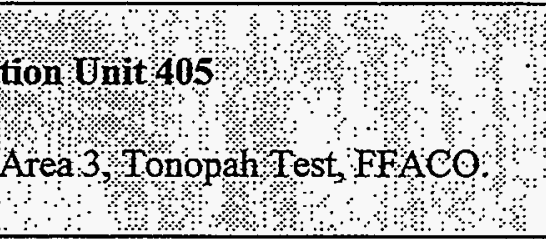 \\
\hline $\begin{array}{l}\text { Corrective Action } \\
\text { Site (CAS) Number }\end{array}$ & $\begin{array}{l}\text { Corrective Action } \\
\text { Site Description }\end{array}$ & General \\
\hline 03-05-002-SW03 & Septic Waste System & Area 3 \\
\hline 03-05-002-SW04 & Septic Waste System & Area 3 \\
\hline 03-05-002-SW07 & Septic Waste System & Area 3 \\
\hline कOETIIdustral & 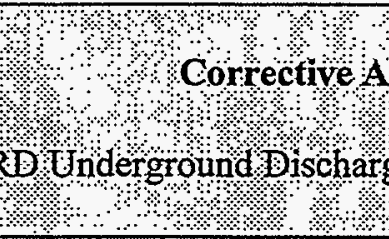 & $\begin{array}{l}\text { tion Gnit } \\
\text { Ponts, } \\
\text { Preas }\end{array}$ \\
\hline $\begin{array}{l}\text { Corrective Action } \\
\text { Site (CAS) Number }\end{array}$ & $\begin{array}{l}\text { Corrective Action } \\
\text { Site Description }\end{array}$ & General Location \\
\hline $03-52-002-0374$ & $\begin{array}{l}\text { Heavy Duty Shop UDP, } \\
\text { Sumps }\end{array}$ & Building 0374 \\
\hline $03-52-003-0358$ & UPS Building UDP & \\
\hline
\end{tabular}


- The items were segregated by waste type and dispositioned accordingly. Waste types were segregated by (1) UXO requiring processing (i.e. detonation), and (2) UXO not requiring processing.

- Potentially hazardous debris/soil,

- Radiologically contaminated debris/soil,

- Recyclable scrap,

- Nonrecyclable, nonhazardous, nonradioactive debris.

UXO requiring processing was explosively processed at a designated area at the Bomblet Pit. After processing, UXO was "demilitarized" either through additional detonations, or cutting. After demilitarization, the remaining metal was recycled as scrap. Other debris was also recycled as scrap metal which resulted in a total of approximately 120 tons of recycled steel and 15 tons of recycled aluminum. In addition, one 55-gallon drum of radiologically-contaminated soil and approximately $2 \mathrm{yd}^{3}$ of radiologically contaminated metal debris were removed from the Five Points Landfill. These items are stored at TTR and await disposal at NTS. A small quantity of hazardous waste was discovered at the Roller Coaster Sewage Lagoons site. This waste was packaged and shipped to a commercial TSD facility. Approximately $350 \mathrm{yd}^{3}$ of nonhazardous, nonradioactive, nonrecyclable debris remain at the sites. This debris awaits approval for disposal at the TTR landfill.

At the conclusion of the Voluntary Corrective Action activities, the Bomblet Pit and Five Points Landfill were considered free of contamination or UXO and a plan is in preparation to provide verification sampling data for clean closure. The other three sites require additional assessment activities, and will be included in subsequent planning efforts.

\subsection{National Environmental Policy Act Compliance ACTIVITIES \& DOCUMENTATION}

The National Environmental Policy Act (NEPA), the nation's most comprehensive legislative and public policy statement on environmental protection, applies to all agencies of the federal government.

The Council on Environmental Quality (CEQ) was created in the Executive Office of the President under the authority of NEPA. CEQ regulations were formally adopted by $D O E$ in August 1979 (10 CFR 1021). DOE NEPA guidelines were last published in full in the Federal Register on December 15, 1987. On April 24, 1992, DOE codified its existing rule of compliance with NEPA (10 CFR 1021). The proposed rule incorporates certain policy initiatives instituted by the Secretary of Energy. 
Although only DOE has the authority to decide the appropriate level of NEPA documentation, SNL assists DOE by drafting appropriate documentation, such as Environmental Checklists (ECLs), Action Description Memoranda (ADMs), and EAs for DOE approval. Such environmental documents serve as vehicles for assessing potential environmental impacts of proposed Federal actions and disclosing federal activities.

At SNL, the Risk Management \& NEPA Department carries out various NEPA-related activities, including consulting and training line-organization personnel in NEPA compliance, coordinating document preparation, maintaining a corporate NEPA document file, and reviewing NEPA documents before submittal to DOE. These responsibilities are documented in the SNL NEPA program (SNL 1991).

\subsubsection{Compliance Summary}

The Secretary of Energy's February 5, 1990, NEPA Notice, SEN-15-90 (Secretary of Energy 1990), with directives intended to bring DOE into full compliance with NEPA, set in motion events that led to a major increase in commitment to comply with the principles and practices underlying NEPA. At TTR, NEPA compliance is a joint effort by SNL with DOE/NV and the Water Resources Center, Desert Research Institute (DRI), University of Nevada System. DRI and EG\&G prepare archaeological and biological surveys and reports. Final reports are submitted to SNL and DOE/NV for transmittal to the State of Nevada, State Historic Preservation Office, (SHPO) for review and decision making.

\subsubsection{Environmental Checklist (ECL)}

An ECL serves to document the use of a categorical exclusion (a category of actions for which neither an EA or an Environmental Impact Statement [EIS] is required).

\subsubsection{Action Description Memorandum (ADM)}

An $\mathrm{ADM}$ is a document containing a concise description of a proposed action and a brief discussion of relevant potential environmental issues. $\mathrm{DOE}$ uses $\mathrm{ADMs}$ to determine the appropriate level of NEPA documentation for proposed actions. In the past, ADMs were also used to document categorical exclusions and to support memo-to-file (MTF) reviews.

The MTF was a unique DOE mechanism established in 1980 to justify not preparing EAs on insignificant actions that had not yet been added to the DOE published list of categorical exclusions. This procedure was followed because the categorical exclusions list was not well defined. The MTF system to exclude actions that are clearly insignificant, but not specifically categorically excluded from detailed NEPA documentation, 
ended on September 30, 1990. At present, actions that are not categorically excluded or covered in approved NEPA documents require preparation of EAs or EISs.

\subsubsection{Environmental Assessment (EA)}

An EA is intended to be a "concise public document" which provides sufficient evidence and analysis to determine whether to prepare an EIS or a Finding of No Significant Impact (FONSI). The EA also aids in the compliance with NEPA when no EIS is required and facilitates preparation of an EIS when one is necessary. A categorical exclusion was applied for in 1995 by DOE/NV and granted by DOE/NV to install solar powered air monitoring equipment at Bunker 2 at TTR.

\subsection{OVERVIEW OF NON-SNL ENVIRONMENTAL MONITORING PROGRAMS AT TTR}

The TTR landowner is the Bureau of Land Management (BLM). The USAF maintains a use permit with BLM that is renewed every 5 years. BLM must approve any new construction, such as roads. In addition to SNL, other agencies and contractors perform environmental monitoring activities at TTR under memoranda of understanding with DOE as follows:

- U.S. Environmental Protection Agency. The EPA Environmental Monitoring Systems Laboratory in Las Vegas, NV, under an interagency agreement with DOE, monitors background radiation at TTR as part of its Off-Site Radiation Monitoring Program. Reports are available through the EPA upon request.

- Water Resources Center, Desert Research Institute, (DRI) University of Nevada System. DRI is under contract with DOE to provide services that include public information activities and radiation monitoring support.

- DRI. Provides and trains station managers to run EPA community monitoring stations at such remote locations as Tonopah and Goldfield. These managers generally are local science teachers. The EPA laboratory in Las Vegas, NV, provides equipment and performs the analysis and reporting. DRI also provides external quality assurance (QA) on field measurements taken by EPA at community monitoring stations. Selected locations are monitored concurrently by DRI with a portable monitoring station (PMS) and Thermoluminescent dosimeters (TLDs). EPA monitoring results are compared to DRI results. 
The QA results that summarize EPA and DRI data at the selected locations are reported annually by DRI. DRI also performs other monitoring, primarily hydrological, for DOE as requested. This may include evaluating environmental impacts due to road construction.

- KMI Services. As part of its TTR support activities, KMI Services personnel perform environmental monitoring activities at TTR. These activities include: water and wastewater sampling, air quality monitoring $\left(\mathrm{PM}_{10}\right.$ and Total Suspended Particulates [TSP]) for SNL and DOE/NV, soil sampling radiation monitoring $(470,000 \mathrm{lb}$. or 31 truckloads of excess salvage was radiation-surveyed prior to shipment to NTS for release for reapplication or auction), preparing local data sections of the annual environmental report and completing the Biannual Hazardous Waste Generation Report for the State of Nevada. KMI Services also manages all hazardous and regulated waste generated by DOE controlled activities at TTR. KMI Services has 13 personnel certified with 40-hour Hazardous Waste Operations and Emergency Response training. This has enabled DOE/NV to use local personnel in environmental clean-up and restoration activities.

Other agencies also prepare reports that may include information on TTR. These reports, described in Volumes 1 through 4 of the Sandia National Laboratories/Nevada Environmental Compliance Summary Report (TTR 1992), are available from the respective agencies. Reports that are prepared on a regular basis include the following:

- Annual Permits/Registration Certificates for Sandia National Laboratories/Nevada-KMI Services.

- Off-site Monitoring Report-Nevada Test Site and Other Test Areas, Quarterly Report-EPA, Dose Assessment Branch, Nuclear Radiation Assessment Division.

- Environmental Monitoring Report: Radiation Monitoring Around United States Nuclear Test Areas, Calendar Year Report-EPA, Dose Assessment Branch, Nuclear Radiation Assessment Division (also published as part of the NTS Annual Site Environmental Report).

- Community Radiation Monitoring Program, Annual Report-DRI. 


\subsection{REPORTABLE RELEASES}

There were no reportable releases caused by DOE or SNL activities in 1995. The USAF had one reportable oil spill on DOE controlled property near the Mellan Air Strip. The spill was caused by leaking smoke generators.

\subsection{OCCURRENCE REPORTING}

There were no SNL caused environmentally related occurrence reports in 1995. The use of Zap Rocket Motors to flash an ordnance pit under remediation resulted in a warning letter from NDEP to DOE/NV and DOE/KAO.

Due to the decline of activities at TTR, it was determined in September of 1994 that seven ZAP Rocket Motors were not likely to be used in a test program at TTR and therefore should be evaluated for reapplication. SNL made inquiries to several Department of Defense (DoD) installations to see if the rocket motors could be reapplied. The most promising reapplication possibility was with the Holloman Air Force Base in New Mexico. After numerous discussions with Holloman it was determined that since there were only seven rocket motors it would not be cost-effective to transport them to Holloman. Another alternative for the rocket motors was to use them as donor explosives in an approved environmental restoration project at TTR. This alternative was evaluated and believed to be a valid reuse of the rocket motors at TTR as indicated in a memorandum dated April 16, 1995, from DOE/KAO to SNL.

While reapplication and reuse activities were being pursued for the rocket motors, the SNL/NM waste management organization began to investigate treatment and disposal options for the rocket motors in the event that they might become waste if no reapplication or reuse could be found. As a contingency, SNL/NM began planning for materials that might become waste prior to being declared waste. However, due to the possibility and promise of reapplication of the rocket motors, at no time were the rocket motors ever declared waste.

DOE/KAO contacted the NDEP on November 9, 1994, to inquire about the process for obtaining an emergency permit under 40 CFR 270.61 in the event that the rocket motors were declared waste. This inquiry was made because there was some concern that the rocket motors would be determined to be unsafe to transport over public roads. Again, this activity was being pursued as a proactive measure to investigate all opportunities for treatment and disposal of the rocket motors.

On September 6, 1995, the NDEP issued a warning letter to DOE/NV and DOE/KAO. The State of Nevada's concern were the disposition of seven ZAP Rocket Motors that were in the custody of SNL TTR. NDEP's position was that these rocket motors had been identified for disposal and their use in a regulated activity without concurrence from NDEP constituted a unauthorized treatment/disposal of a waste without a permit. 
This page intentionally blank. 


\title{
5.0 ENVIRONMENTAL SURVEILLANCE AT TTR IN 1995
}

\subsection{SNL ENVIRONMENTAL SURVEILLANCE}

\begin{abstract}
Tn August 1995, staff from SNL's Air Quality Department Environmental Surveillance program collected soil samples at TTR. Limited air monitoring samples were collected from May to December in 1995. The overall objectives of the environmental surveillance program are to detect the potential migration of contaminated material related to on-site operations and also to determine the potential impact (if any) of site-related activities to the population and the surrounding environment. The specific objectives include the annual sampling of the long-term, routine, environmental surveillance locations and supplementing the environmental baseline data collected in 1992 (SNL 1992a). Additional baseline-related sampling was performed in 1994 in areas where SNL has had a long-term or continued presence at TTR. The annual sampling of the routine surveillance locations provides information related to the long-term environmental conditions and trends of the site.
\end{abstract}

To support the objectives of the Environmental Surveillance program, soil samples were collected in three distinct areas: off-site, site perimeter, and on-site. The off-site locations provide a sampling of environmental conditions unrelated to SNL activities at TTR. Data collected at these locations serve as a reference point to compare data collected at perimeter and on-site locations. The perimeter locations are used to monitor the site boundary for potential contamination migrating either onto or off of TTR. Onsite locations are near areas of known contamination or potential sources of contamination, or in areas where contamination, if present, would be expected to accumulate. All samples collected in 1995 were from areas of uncontrolled access (outside of the on-site controlled areas).

Most routine environmental surveillance locations remain essentially the same from year to year. Long-Term locations are added as necessary to monitor new operations or to supplement data from existing locations. Due to limited resources, the sampling locations, number of samples, and analyses performed were prioritized based on the following: (1) contaminants believed to be present, (2) contamination considered readily dispersible by environmental factors (e.g., wind or rain), and (3) areas with the greatest potential for impact the public, workers, and the environment. 
A long-term thermoluminescent dosimeter (TLD) network was established in January 1994. Environmental TLDs have been placed at various locations off-site, at the site perimeter, and on-site to measure gamma radiation.

\section{Sample Collection and Analysis}

Soil samples were gathered in accordance with Environmental Sampling Procedure (SNL 1992b), the activity-specific environment, safety, and health (ES\&H) Standard Operating Procedure (SOP). In cases of replicate sampling, only the first sample collected (sample A) was used in summary calculations to avoid skewing summary data toward replicate sample data.

As part of the 1995 surveillance activities, 54 locations were sampled: 14 from off-site, five from the site perimeter, five from around the On-Base Housing Area, six from the South Plume Area, three from the 554th Range Squadron O\&M Complex, 10 from the Range Operations Center, and 11 from various on-site locations. All soil samples were analyzed for 20 metals by the inductively coupled plasma (ICP) method, total uranium $\left(\mathrm{U}_{\mathrm{tot}}\right)$, and by gamma spectroscopy. Samples collected in 1995 were analyzed by a different analytical laboratory than who performed the analysis in the past. Some minor variation in analytical results is expected when changing analytical laboratories.

For samples collected from on-site or the site perimeter, total uranium $\left(\mathrm{U}_{\text {tot }}\right)$ cesium- 137 (Cs-137), and non-radiological metal concentrations were compared to the upper 95 percent (mean plus two standard deviations) confidence limit and the range of values from those samples collected off-site. Individual samples with values greater than the upper 95 percent confidence interval and greater than the range of observed values were considered potentially contaminated.

$\mathrm{PM}_{10}$ air monitors sample air particulates of 10 microns $(\mu \mathrm{m})$ or less. This size of particulate is considered respirable. $\mathrm{PM}_{10}$ air monitoring was conducted at three locations on TTR: the 554th Range Squadron O\&M Complex, Station 14 (STA-14), and Well 6. The 554th Range Squadron O\&M Complex was monitored because it is the closest onsite work location of non-SNL employees and to the contaminated Clean Slate sites. STA-14 is located in the general vicinity between Clean Slates 1 and 3 (the potential sources of airborne contamination) and the SNL/NV-occupied portions of TTR. Well 6 is the main TTR water well located near the Range Operations Center where the majority of SNL/NV personnel work. Samples were gathered in accordance with TOP-94-07 (Culp 1994).

Air filters were exchanged weekly and analyzed samples consisted of monthly composites. All composite samples were analyzed for gross alpha, gross beta, isotopic plutonium, $U_{\text {tot }}$ and $20 \mathrm{ICP}$ non-radiological metals, and by gamma spectroscopy. 


\subsection{SNL Radiological SurVeILlance Results}

\subsubsection{Soil Sampling}

Figure B-1 through B-11 of Appendix B shows the 1995 environmental surveillance soil sampling locations. Table B-1 through B-11 of Appendix B list the individual radiological sample results. Table 5-1 summarizes the radiological soil sampling data. The summary includes the mean, standard deviation, and range of values for the off-site samples, as well as the range of values for the on-site sampled areas.

The sample analysis scheme used for soil samples required $U_{\text {tot }}$ and gamma spectral analysis for all samples. If the gamma spectral analysis detected Am-241 in concentrations greater than the detection limit for Am-241, then isotopic plutonium analysis would be performed. No soil samples had Am-241 concentrations reported as greater than the analytical detection limit, therefore no isotopic plutonium analysis was performed.

Table 5-1. Radiological summary data for soil samples collected at TTR in 1995.

\begin{tabular}{|c|c|c|c|}
\hline Location & Samp & U.tot/. & $\begin{array}{l}\mathrm{Cs}-137 \\
(\mathrm{pCi} / \mathrm{g})\end{array}$ \\
\hline Off-Site & 14 & $15.4-3.25$ & $0.00-1.43$ \\
\hline Mean & & 2.43 & 0.46 \\
\hline Standard Deviation & & 0.53 & 0.44 \\
\hline 554th Range O\&M & 3 & $2.35-2.63$ & $0.00-0.25$ \\
\hline On-Base Housing & 5 & $1.23-2.44$ & $0.00-0.32$ \\
\hline Site Perimeter & 5 & $1.06-2.08$ & $0.02-0.58$ \\
\hline Range Operations Center & 10 & $1.58-4.01$ & $0.00-0.25$ \\
\hline South Plume Area & 6 & $1.55-2.52$ & $0.37-0.85$ \\
\hline Various On-Site Locations & 11 & $1.73-4.30$ & $0.03-0.62$ \\
\hline
\end{tabular}




\subsubsection{Off-site Soil Sampling}

Results from the 14 off-site soil sampling locations were consistent with previous years' results and are believed to represent the normal, expected range of values (see Figure B-1 and Table B-1 ).

\subsubsection{On-site Soil Sampling}

Site Perimeter- Five samples were collected from the TTR site perimeter (see Figure B-2 and Table B-2 ). All Cs-137 and $\mathrm{U}_{\text {tot }}$ results were indistinguishable from off-site concentrations.

On-Base Housing Area- Five samples were collected from near the On-Base Housing Area (see Figure B-3 and Table B-3). All Cs-137 and $U_{\text {tot }}$ results were indistinguishable from off-site concentrations.

South Plume Area- Six samples were collected from the South Plume Area (see Figure B-4 and Table B-4 ). All Cs-137 and $U_{\text {tot }}$ results were indistinguishable from off-site concentrations.

554th Range Squadron O\&M Complex- Three samples were collected from the area around the 554th Range Squadron O\&M Complex (see Figure B-5 and Table B-5). All Cs-137 and $U_{\text {tot }}$ results were indistinguishable from off-site concentrations.

Range Operations Center- Ten samples were collected from the area around the Range Operations Center (see Figure B-6, B-7, \& B-8 and Table B-6). All Cs-137 results were indistinguishable from off-site concentrations. The sample collected from location OC19 showed elevated concentration of $U_{\text {tot }}$. All other locations were indistinguishable from off-site concentrations.

Various On-Site Locations- Eleven samples were collected from various locations onsite (see Figure B-9, B-10 \& B-11 and Table B-7). All Cs-137 results were indistinguishable from off-site concentrations. The sample collected from location T-20 showed elevated concentration of $U_{\text {tot }}$. Location T-20 is in the vicinity of the Hard Target near a fenced area suspected of being contaminated with DU. All other locations were indistinguishable from off-site concentrations.

The off-site distribution of sample concentrations serves as a reference to compare on-site samples. Due to the limited size of the off-site sampling (14 samples) this comparison should not be considered as exact in the identification of potential contamination. Some locations which appear to be marginally elevated above off-site concentrations may not be contaminated, but rather show the normal, expected, variation in sample concentration. Also, some differences are to be expected when switching analytical laboratories. The 
laboratory that performed the 1995 analyses is not believed to perform as sensitive of measurements as the previously used laboratory.

\subsubsection{Results of Radiological Air Sampling}

Tables 5-2 through 5-4 provide results from the routine radiological the $\mathrm{PM}_{10}$ monitoring conducted at the 554th Range Squadron O\&M Complex, STA-14, and Well 6, respectively. Measured results are listed for gross alpha, gross beta, isotopic plutonium, and $U_{\text {tot }}$. Reported results are net radionuclide concentrations (laboratory reported values minus filter blanks). The $U_{\text {tot }}$ concentrations were converted into the isotopic uranium constituents assuming the uranium isotopes were present in their natural abundance. Analysis was performed for $U_{\text {tot, }} A m-241$, and isotopic plutonium because these radionuclides are potential contaminants at TTR. Gross alpha and gross beta analysis was performed as a general indication of the radionuclide air quality.

The measured radionuclide concentrations are all believed to be small and consistent with previously measured values at TTR and consistent between sampling locations. The error term associated with the measured values (with the exception of $U_{\text {tot }}$ which was measured based on its non-radiological properties) are relatively large when compared to the base value. Americium-241 results were always less than the associated detection limit for this radionuclide for analysis by gamma spectroscopy.

\subsubsection{Results of the TLD Program Sampling}

As part of the long-term, routine, environmental surveillance program at TTR, SNL began an ambient gamma-radiation program in January 1994. This program includes a TLD monitoring network to measure radiation exposure at five community (off-site) locations, four perimeter locations, and 13 on-site locations. Table 5-5 summarizes the TLD measurements of annual radiation exposure off-site, at the site perimeter, and onsite. Table B-8 of Appendix B lists the TLD locations and results. Exposure results include contributions from natural background and man-made radiation (if any).

The average annual exposure for the perimeter and off-site locations were $143 \pm 19$ milliroentgen per year ( $\mathrm{mR} / \mathrm{yr}$ ) and $120 \pm 14 \mathrm{mR} / \mathrm{yr}$, respectively. The average on-site exposure was $144 \pm 22 \mathrm{mR} / \mathrm{yr}$. Individual on-site values ranged from $122 \pm 13 \mathrm{mR} / \mathrm{yr}$ to $210 \pm 26 \mathrm{mR} / \mathrm{yr}$. 
Table 5-2. $1995 \mathrm{PM}_{10}$ radiological air monitoring results for the 554th Range Squadron O\&M Complex (Continues).

\begin{tabular}{|c|c|c|c|}
\hline Composite & malyte & $\begin{array}{l}\text { Concentration } \\
(\text { p@i) }\end{array}$ & $(\mathrm{pCl} / \mathrm{m})$ \\
\hline \multirow[t]{8}{*}{$\underline{\text { May }}$} & Gross Alpha & $3.28 \mathrm{E}-02$ & $1.87 \mathrm{E}-02$ \\
\hline & Gross Beta & $4.15 \mathrm{E}-02$ & $1.81 E-02$ \\
\hline & Plutonium-238 & $7.98 \mathrm{E}-05$ & $1.02 \mathrm{E}-03$ \\
\hline & Plutonium-239+240 & $5.98 \mathrm{E}-04$ & 4.79E-04 \\
\hline & Uranium, total (ug/m3) & $1.64 \mathrm{E}-02$ & \\
\hline & U-238 & $5.43 \mathrm{E}-03$ & \\
\hline & U-234 & $5.84 \mathrm{E}-03$ & \\
\hline & U-235 & $2.54 \mathrm{E}-04$ & \\
\hline \multirow[t]{8}{*}{ June } & Gross Alpha & $3.30 \mathrm{E}-02$ & $2.59 \mathrm{E}-02$ \\
\hline & Gross Beta & $6.85 \mathrm{E}-02$ & 2.62E-02 \\
\hline & Plutonium-238 & $8.19 \mathrm{E}-04$ & 8.19E-04 \\
\hline & Plutonium-239+240 & $1.18 \mathrm{E}-03$ & $1.18 \mathrm{E}-03$ \\
\hline & Uranium, total & $1.54 \mathrm{E}-02$ & \\
\hline & U-238 & $5.10 \mathrm{E}-03$ & \\
\hline & U-234 & $5.48 \mathrm{E}-03$ & \\
\hline & U-235 & $2.39 \mathrm{E}-04$ & \\
\hline \multirow[t]{8}{*}{ August } & Gross Alpha & 4.63E-02 & $1.95 \mathrm{E}-02$ \\
\hline & Gross Beta & $7.69 \mathrm{E}-02$ & $1.76 \mathrm{E}-02$ \\
\hline & Plutonium-238 & 2.70E-04 & $1.93 \mathrm{E}-04$ \\
\hline & Plutonium-239+240 & 1.79E-04 & 3.63E-04 \\
\hline & Uranium, total & $1.45 \mathrm{E}-02$ & \\
\hline & U-238 & $4.80 \mathrm{E}-03$ & \\
\hline & $\mathrm{U}-234$ & $5.16 \mathrm{E}-03$ & \\
\hline & U-235 & $2.25 \mathrm{E}-04$ & \\
\hline \multirow[t]{8}{*}{ September } & Gross Alpha & $2.10 \mathrm{E}-02$ & $1.23 \mathrm{E}-02$ \\
\hline & Gross Beta & 6.37E-02 & $1.05 \mathrm{E}-02$ \\
\hline & Plutonium-238 & $-3.65 \mathrm{E}-05$ & $3.44 \mathrm{E}-04$ \\
\hline & Plutonium-239+240 & 7.47E-05 & $1.15 \mathrm{E}-04$ \\
\hline & Uranium, total & $-6.20 \mathrm{E}-04$ & \\
\hline & U-238 & $-2.05 \mathrm{E}-04$ & \\
\hline & $\mathrm{U}-234$ & $-2.21 \mathrm{E}-04$ & \\
\hline & U-235 & $-9.61 \mathrm{E}-06$ & \\
\hline
\end{tabular}


Table 5-2. $\mathrm{PM}_{10}$ radiological air monitoring results for the 554th Range Squadron O\&M Complex (Concluded).

\begin{tabular}{|c|c|c|c|}
\hline $\begin{array}{r}\text { Composite } \\
\text { }\end{array}$ & balyte & $\begin{array}{l}\text { Concentrat } \\
\left(\mathrm{pci} / \mathrm{m}^{3}\right)\end{array}$ & $\begin{array}{c}\text { Error } \\
\left(\mathrm{pCi} / \mathrm{m}^{3}\right)\end{array}$ \\
\hline \multirow[t]{8}{*}{ October } & Gross Alpha & $3.68 \mathrm{E}-03$ & $9.64 \mathrm{E}-03$ \\
\hline & Gross Beta & $2.36 \mathrm{E}-02$ & $9.22 \mathrm{E}-03$ \\
\hline & Plutonium-238 & $-2.87 \mathrm{E}-04$ & $6.46 \mathrm{E}-04$ \\
\hline & Plutonium-239+240 & $3.35 \mathrm{E}-04$ & $2.29 \mathrm{E}-04$ \\
\hline & Uranium, total & $-5.04 \mathrm{E}-04$ & \\
\hline & U-238 & $-1.67 \mathrm{E}-03$ & \\
\hline & $\mathrm{U}-234$ & $-1.79 \mathrm{E}-03$ & \\
\hline & U-235 & $-7.81 \mathrm{E}-05$ & \\
\hline \multirow[t]{8}{*}{ November } & Gross Alpha & $-2.07 \mathrm{E}-02$ & $1.11 \mathrm{E}-02$ \\
\hline & Gross Beta & $5.61 \mathrm{E}-02$ & $1.31 \mathrm{E}-02$ \\
\hline & Plutonium-238 & 4.74E-05 & $2.53 \mathrm{E}-04$ \\
\hline & Plutonium-239+240 & $-3.16 \mathrm{E}-05$ & $7.90 \mathrm{E}-05$ \\
\hline & Uranium, total & $7.49 \mathrm{E}-04$ & \\
\hline & $\mathrm{U}-238$ & $2.48 \mathrm{E}-04$ & \\
\hline & $\mathrm{U}-234$ & 2.67E-04 & \\
\hline & $\mathrm{U}-235$ & $1.16 \mathrm{E}-05$ & \\
\hline \multirow[t]{6}{*}{ December } & Gross Alpha & $6.04 \mathrm{E}-03$ & $7.61 \mathrm{E}-03$ \\
\hline & Gross Beta & $7.16 \mathrm{E}-03$ & $1.21 \mathrm{E}-02$ \\
\hline & Uranium, total & $-2.17 \mathrm{E}-03$ & \\
\hline & U-238 & $-7.18 \mathrm{E}-04$ & \\
\hline & U-234 & $-7.73 E-04$ & \\
\hline & U-235 & $-3.36 \mathrm{E}-05$ & \\
\hline
\end{tabular}

Note: $\mathrm{pCi} / \mathrm{m}^{3}=$ picocuries per cubic meter; $\mu \mathrm{g} / \mathrm{m}^{3}=$ micrograms per cubic meter; Americium-241 not detected. 


\section{. IIIN}

Table 5-3. $1995 \mathrm{PM}_{10}$ radiological air monitoring results for Station 14 (Continues).

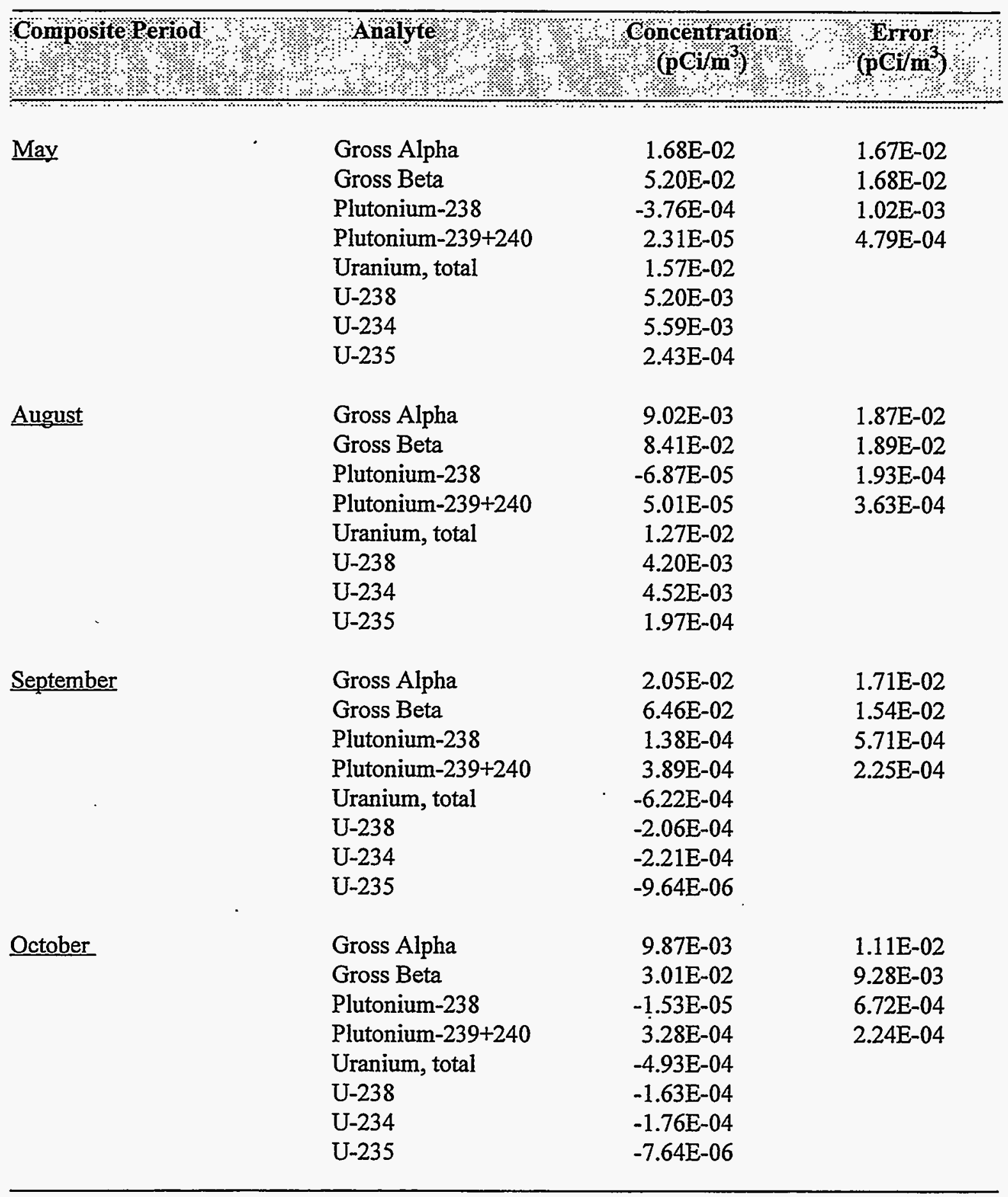


Table 5-3. $1995 \mathrm{PM}_{10}$ radiological air monitoring results for Station 14 (Concluded).

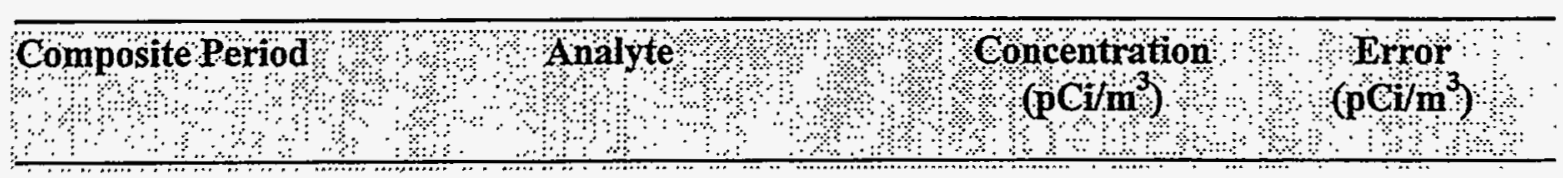

November

Gross Alpha
Gross Beta
Plutonium-238
Plutonium-239+240
Uranium, total
U-238
U-234
U-235

$-3.90 \mathrm{E}-03$

$1.52 \mathrm{E}-02$

2.97E-02

$1.47 \mathrm{E}-02$

$-9.13 \mathrm{E}-05$

3.39E-04

$1.41 \mathrm{E}-04$

1.27E-04

$1.84 \mathrm{E}-03$

$6.09 \mathrm{E}-04$

$6.55 \mathrm{E}-04$

$2.58 \mathrm{E}-05$

December

Gross Alpha
Gross Beta
Uranium, total
U-238
U-234
U-235

$\begin{array}{rl}3.14 \mathrm{E}-03 & 9.08 \mathrm{E}-03 \\ -1.47 \mathrm{E}-02 & 1.75 \mathrm{E}-02 \\ -2.31 \mathrm{E}-03 & \\ -7.65 \mathrm{E}-04 & \\ -8.22 \mathrm{E}-04 & \\ -3.58 \mathrm{E}-05 & \end{array}$

Note: $\mathrm{pCi} / \mathrm{m}^{3}=$ picocuries per cubic meter; $\mu \mathrm{g} / \mathrm{m}^{3}=$ micrograms per cubic meter; Americium-241 not detected. 
Table 5-4. $1995 \mathrm{PM}_{10}$ radiological air monitoring results for Well 6 (Continues).

\begin{tabular}{|c|c|c|c|}
\hline Compositeperod & Analyte & \multicolumn{2}{|c|}{ 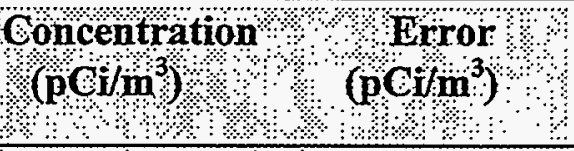 } \\
\hline \multirow[t]{8}{*}{ May } & Gross Alpha & $3.48 \mathrm{E}-02$ & $2.56 \mathrm{E}-02$ \\
\hline & Gross Beta & $1.33 \mathrm{E}-01$ & 2.64E-02 \\
\hline & Plutonium-238 & $7.34 \mathrm{E}-04$ & 2.20E-03 \\
\hline & Plutonium-239+240 & 1.17E-03 & $7.98 \mathrm{E}-04$ \\
\hline & Uranium, total & $6.90 \mathrm{E}-03$ & \\
\hline & $\mathrm{U}-238$ & $2.28 \mathrm{E}-03$ & \\
\hline & $\mathrm{U}-234$ & $2.46 \mathrm{E}-03$ & \\
\hline & U-235 & $1.07 \mathrm{E}-04$ & \\
\hline \multirow[t]{8}{*}{ June } & Gross Alpha & 2.63E-02 & $1.84 \mathrm{E}-02$ \\
\hline & Gross Beta & $6.13 \mathrm{E}-02$ & $1.78 \mathrm{E}-02$ \\
\hline & Plutonium-238 & $1.93 \mathrm{E}-04$ & $1.93 \mathrm{E}-04$ \\
\hline & Plutonium-239+240 & 3.63E-04 & $3.63 \mathrm{E}-04$ \\
\hline & Uranium, total & $1.61 \mathrm{E}-02$ & \\
\hline & $U-238$ & $5.33 \mathrm{E}-03$ & \\
\hline & U-234 & 5.73E-03 & \\
\hline & U-235 & $2.50 \mathrm{E}-04$ & \\
\hline \multirow[t]{8}{*}{ August } & Gross Alpha & $8.39 \mathrm{E}-03$ & $1.58 \mathrm{E}-02$ \\
\hline & Gross Beta & $6.43 \mathrm{E}-02$ & $1.75 \mathrm{E}-02$ \\
\hline & Plutonium-238 & $-9.62 \mathrm{E}-05$ & $1.28 \mathrm{E}-03$ \\
\hline & Plutonium-239+240 & $-5.63 \mathrm{E}-05$ & $5.48 \mathrm{E}-04$ \\
\hline & Uranium, total & $1.37 \mathrm{E}-02$ & \\
\hline & U-238 & $4.53 \mathrm{E}-03$ & \\
\hline & U-234 & 4.88E-03 & \\
\hline & U-235 & $2.12 \mathrm{E}-04$ & \\
\hline \multirow[t]{8}{*}{ September } & Gross Alpha & $1.64 \mathrm{E}-02$ & 1.13E-02 \\
\hline & Gross Beta & $2.81 \mathrm{E}-02$ & $9.78 \mathrm{E}-03$ \\
\hline & Plutonium-238 & $-2.63 E-05$ & $3.36 \mathrm{E}-04$ \\
\hline & Plutonium-239+240 & $1.49 \mathrm{E}-04$ & $1.37 \mathrm{E}-04$ \\
\hline & Uranium, total & $-6.25 E-04$ & \\
\hline & U-238 & $-2.07 \mathrm{E}-04$ & \\
\hline & U-234 & $-2.23 E-04$ & \\
\hline & $\mathrm{U}-235$ & $-9.69 \mathrm{E}-06$ & \\
\hline
\end{tabular}


Table 5-4. 1995 $\mathrm{PM}_{10}$ radiological air monitoring results for Well 6 (Concluded).

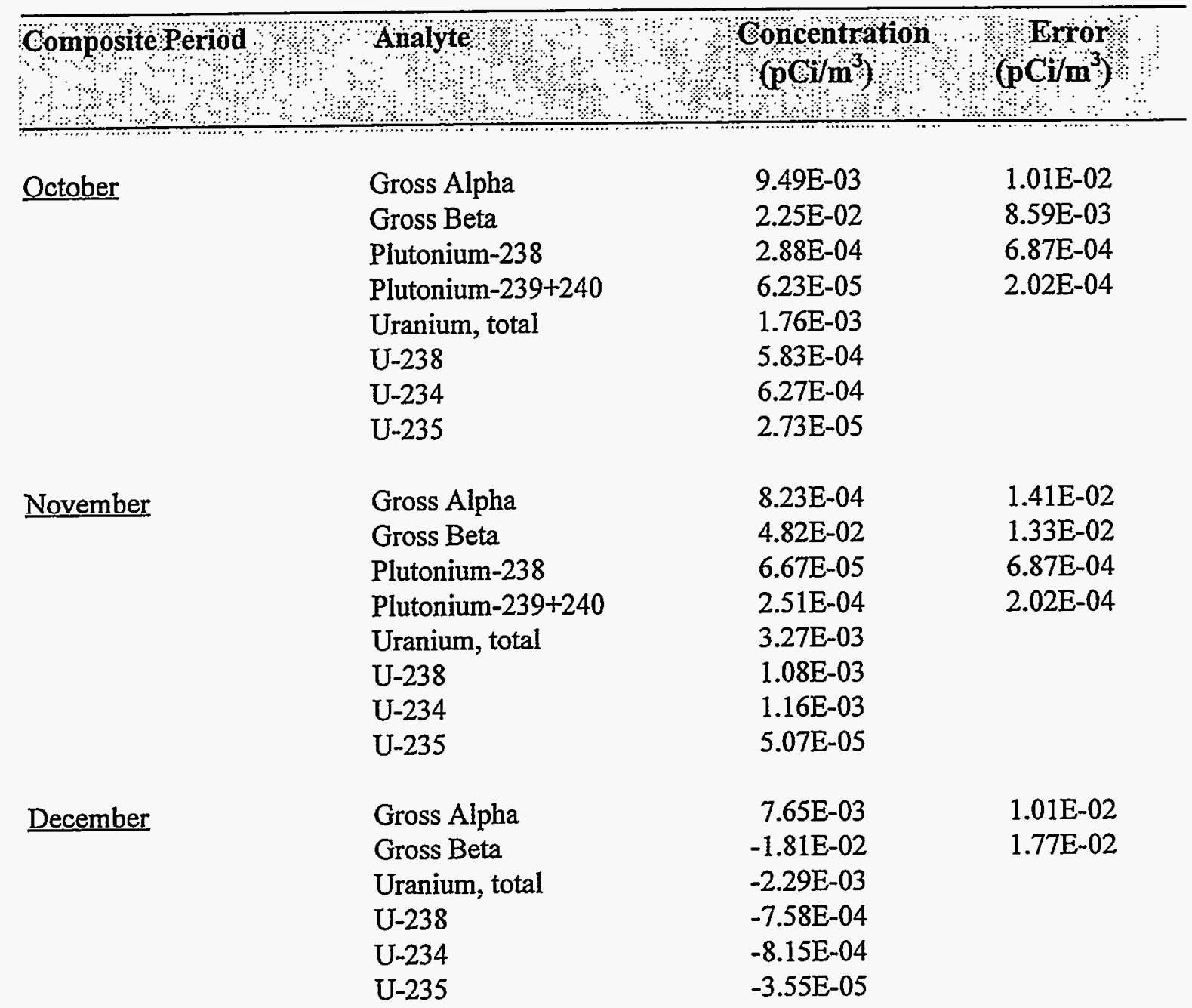

Note: $\mathrm{pCi} / \mathrm{m}^{3}=$ picocuries per cubic meter; $\mu \mathrm{g} / \mathrm{m}^{3}=$ micrograms per cubic meter; Americium-241 not detected. 
Table 5-5. Summary of Thermoluminescent Dosimeter Measurements for 1995.

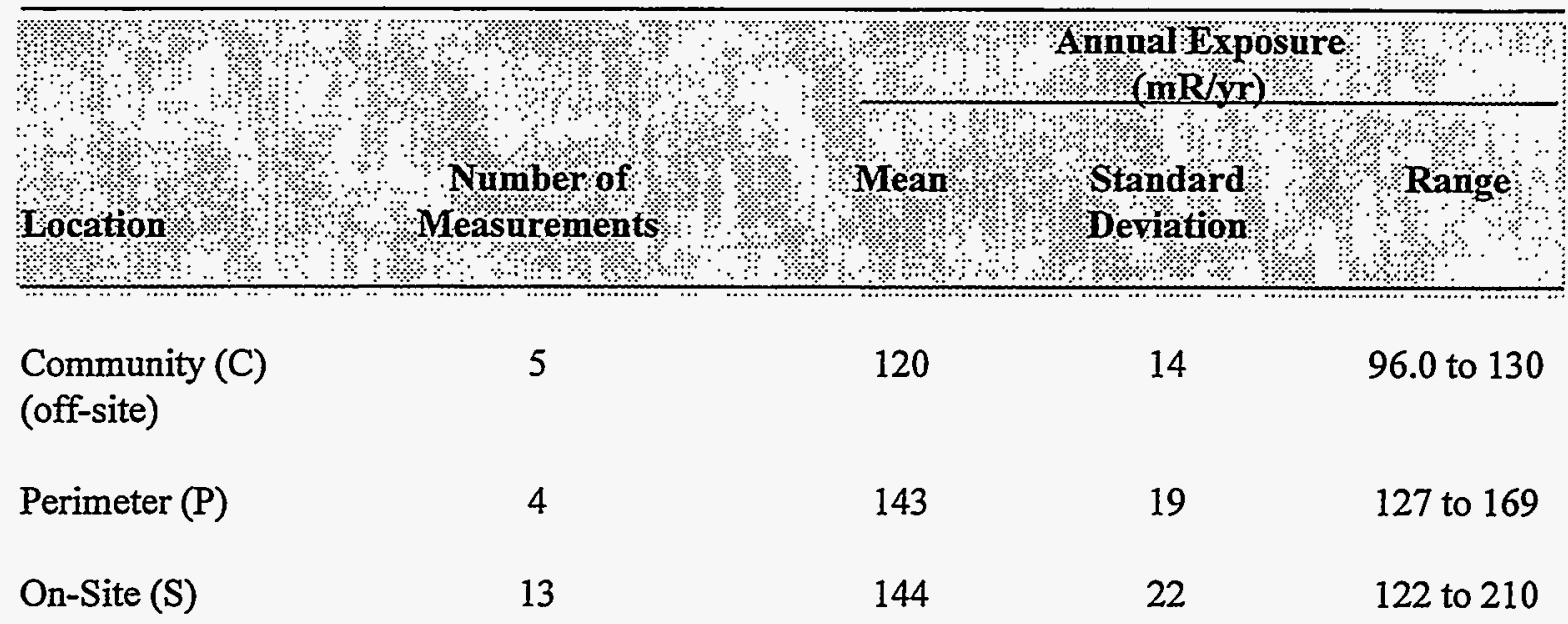

Note: $\mathrm{mR} / \mathrm{yr}=$ milliroentgen per year.

\subsection{SNL Non-RAdiological SuRVEILLANCE RESULTS}

\subsubsection{Soil Sampling}

Figures B-1 through B-11 of Appendix B show the 1995 environmental surveillance soil sampling locations. Tables $\mathrm{C}-1$ through $\mathrm{C}-7$ of Appendix $\mathrm{C}$ list the individual nonradiological sample results for the soil sampling.

\subsubsection{Off-Site Soil Sampling}

Non-radiological results from the 14 off-site soil sampling locations were consistent with previous years' results and are believed to represent the normal, expected range of values for the 20 analyzed metals (see Figure B-1 and Table C-1).

\subsubsection{On-Site Soil Sampling}

Site Perimeter - Five samples were collected from the TTR site perimeter (see Figure B2 and Table C-2). Sample T-08 contained elevated concentrations of cadmium (Cd); sample T-11 contained elevated concentrations of $\mathrm{Cd}$, iron $(\mathrm{Fe})$, manganese $(\mathrm{Mn})$, molybdenum (Mo), vanadium (V), and zinc ( $\mathrm{Zn}$ ); and sample T-13 contained elevated concentrations of $\mathrm{Zn}$. All other analyses performed on samples collected from the site perimeter were indistinguishable from off-site concentrations. 
On-Base Housing Area - Five samples were collected from near the On-Base Housing Area (see Figure B-3 and Table C-3). Sample T-36 contained elevated concentrations of Cr. All other analyses performed on sampled collected from the On-Base Housing Area were indistinguishable from off-site concentrations.

South Plume Area - Six samples were collected from the South Plume Area (see Figure B-4 and Table C-4). Sample T-14 contained elevated concentrations of barium (Ba) and silver (Ag); sample $\mathrm{T}-18$ was found to be elevated in $\mathrm{Ag}$; and sample $\mathrm{T}-19$ was found to be elevated in nickel $(\mathrm{Ni})$, and silicon dioxide $\left(\mathrm{SiO}_{2}\right)$. All other analyses performed on samples collected from the South Plume Area were indistinguishable from off-site concentrations.

554th Range Squadron O\&M Complex - Three samples were collected from that area around the 554th Range Squadron O\&M Complex (see Figure B-5 and Table C-5). Sample OM-03 was found to be elevated in Cd. All other analyses performed on samples collected from the area around the 554th Range Squadron O\&M Complex were indistinguishable from off-site concentrations.

Range Operations Center - Ten samples were collected from the area around the Range Operations Center (see Figure B-6, B-7, \& B-8 and Table C-6). Sample OC-03 was found to be elevated in beryllium (Be) and $\mathrm{Cd}$; OC-10 was elevated in $\mathrm{Cd}$; OC-19 was found to be elevated in $\mathrm{CD}$ and $\mathrm{Zn}$; OC-13 and OC-22 were elevated in $\mathrm{Zn}$; and $\mathrm{OC}-23$ was elevated in Thallium (Th). All other analyses performed on samples collected from the area around the Range Operations Center were indistinguishable from off-site concentrations.

Various On-Site Locations - Eleven samples were collected from various locations onsite (see Figure B-9, B-10, \& B-11 and Table C-7). Sample T-20 was found to be elevated in $\mathrm{SiO}_{2}$; and $\mathrm{T}-21$ was found to be elevated in aluminum (Al), $\mathrm{Be}, \mathrm{Fe}, \mathrm{Mg}$, manganese $(\mathrm{Mn}), \mathrm{Ni}$, Potassium $(\mathrm{K}), \mathrm{SiO}_{2}, \mathrm{Ag}$, Sodium (Na), and V. All other analyses performed on samples collected from the various locations on-site were indistinguishable from off-site concentrations.

The off-site distribution of sample concentrations serves as a reference to compare with on-site samples. Due to the limited size of the off-site sampling (14 samples), the wide range of concentrations of some constituents, and the potential differences in the geological makeup of some of the sample collections areas, this comparison should not be considered as exact in the identification of contamination. Some locations with metal concentrations marginally elevated above off-site may in fact not be contaminated, but rather show the normal, expected, variation in sample concentration. Where sample concentrations are considerably greater than off-site, and greater than the range of off-site values, it was assumed that contamination is potentially present. 


\subsubsection{Results of Non-radiological Air Sampling}

Tables 5-6 through 5-9 provide the results from the routine nonradiological $\mathrm{PM}_{10}$ air monitoring conducted at the 554th Range Squadron O\&M Complex, STA-14 and Well 6, respectively. Analysis was performed by the ICP technique which reports 20 metals. The table results exclude those metals which are major constituents of the glass fiber filters used in $\mathrm{PM}_{10}$ air monitoring (i.e., $\mathrm{Al}, \mathrm{Ca}, \mathrm{Fe}, \mathrm{Mg}, \mathrm{Si}, \mathrm{Na}, \mathrm{K}$ ).

The measured metal concentrations are all believed to be consistent at each location and between locations as well as consistent with previous years measurements. Some of the variation in measured concentrations are believed to be related to environmental factors (i.e., wind and dust loading of filters) and to the change in analytical laboratories performing the analysis. In either case, these differences are not considered indicative of environmental contamination.

\subsection{EnVironmental Perspective}

It is generally accepted that once Pu comes in contact with soil in the environment, it becomes firmly attached to the host particle. Previous studies (Tamura 1974, 1975, 1976) of soil samples from safety-shot areas at the NTS showed Pu particle-size association was primarily with coarse silts (50 to $20 \mu \mathrm{m}$ ) and fine sands (125 to $50 \mu \mathrm{m}$ ). Whereas the inhalation of finer sizes $(<7 \mu \mathrm{m}$ diameter at a density of 1 gram per cubic centimeter $\left[\mathrm{g} / \mathrm{cm}^{3}\right]$ ) is considered most hazardous (Tamura 1976), the coarser soil particles should not be ignored with regard to environmental transport, as these particle sizes are readily subjected to movement by wind (Leavitt 1980). Leavitt (1976) studied five safety-shot areas in Nevada and reported that the wind had a dominant influence on the surface texture of the desert soil by depositing soil fines around the base of brush or vegetation. Another study (Tamura 1977) discussed the occurrence of sandy mounds formed under desert shrubbery. These mounds were formed by the filtering action of the desert vegetation in intercepting saltation and creeping particles. The vegetation intercepts the material being moved through the environment by wind. This study and additional studies found that in Pu-contaminated areas, the Pu activity levels were higher in the desert mounds than in the contiguous desert pavement (areas without vegetation). This demonstrates the effect of wind erosion in dispersal of contaminated material. The Tamura (1977) study also discussed evidence of Pu migration downward into the soil profile. 
Table 5-6. $1995 \mathrm{PM}_{10}$ non-radiological air monitoring results for the 554th Range Squadron O\&M Complex (Continues).

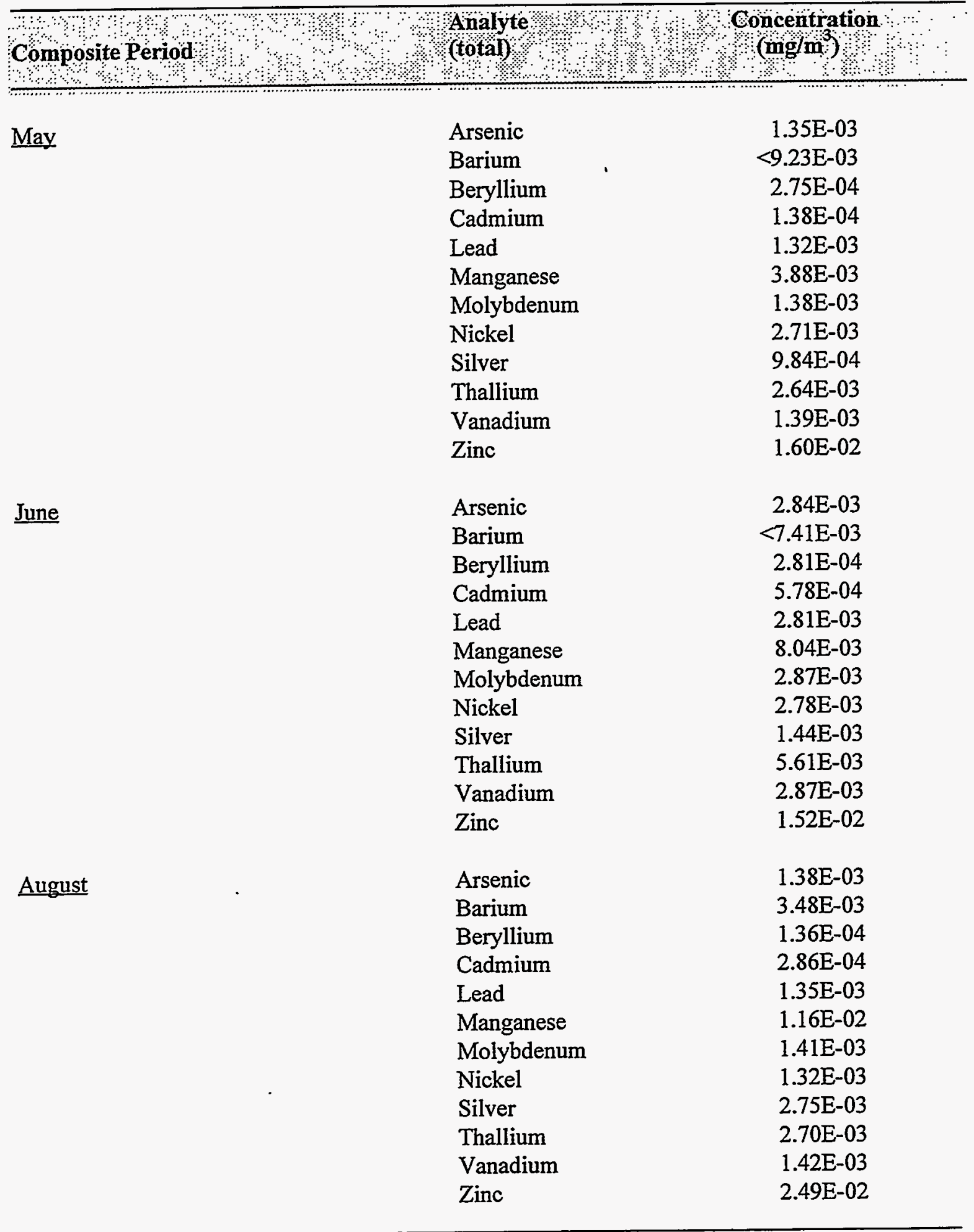


Table 5-6. $1995 \mathrm{PM}_{10}$ non-radiological air monitoring results for the 554th Range Squadron O\&M Complex (Continued).

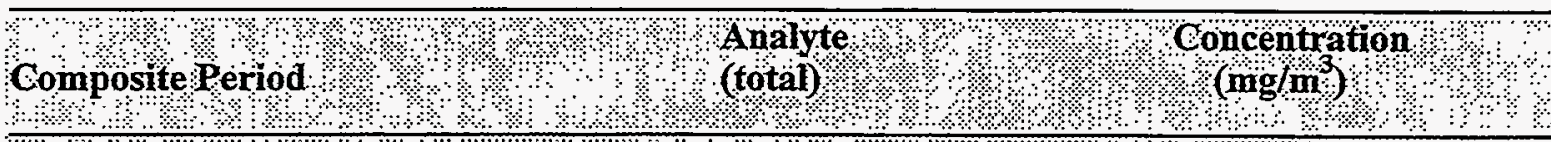

September

Arsenic
Barium
Beryllium
Cadmium
Lead
Manganese
Molybdenum
Nickel
Silver
Thallium
Vanadium
Zinc

October

November

$\begin{array}{lr}\text { Arsenic } & 2.59 \mathrm{E}-03 \\ \text { Barium } & 5.86 \mathrm{E}-02 \\ \text { Beryllium } & 6.60 \mathrm{E}-05 \\ \text { Cadmium } & 3.77 \mathrm{E}-06 \\ \text { Lead } & 2.26 \mathrm{E}-03 \\ \text { Manganese } & 5.65 \mathrm{E}-03 \\ \text { Molybdenum } & 1.27 \mathrm{E}-05 \\ \text { Nickel } & 1.71 \mathrm{E}-03 \\ \text { Silver } & 2.83 \mathrm{E}-05 \\ \text { Thallium } & 7.32 \mathrm{E}-04 \\ \text { Vanadium } & 1.48 \mathrm{E}-05 \\ \text { Zinc } & 3.16 \mathrm{E}-02 \\ & \\ \text { Arsenic } & <2.87 \mathrm{E}-05 \\ \text { Barium } & 2.86 \mathrm{E}-02 \\ \text { Beryllium } & <5.64 \mathrm{E}-06 \\ \text { Cadmium } & <1.66 \mathrm{E}-07 \\ \text { Lead } & <6.06 \mathrm{E}-05 \\ \text { Manganese } & 2.80 \mathrm{E}-03 \\ \text { Molybdenum } & 2.75 \mathrm{E}-04 \\ \text { Nickel } & 4.40 \mathrm{E}-04 \\ \text { Silver } & 8.25 \mathrm{E}-05 \\ \text { Thallium } & 2.68 \mathrm{E}-03 \\ \text { Vanadium } & 3.22 \mathrm{E}-06 \\ \text { Zinc } & 8.38 \mathrm{E}-03\end{array}$

$5.65 \mathrm{E}-03$

$$
\begin{aligned}
& <4.00 \mathrm{E}-05 \\
& <1.53 \mathrm{E}-02 \\
& <6.74 \mathrm{E}-06 \\
& <1.32 \mathrm{E}-06 \\
& <7.16 \mathrm{E}-05 \\
& <4.48 \mathrm{E}-05 \\
& <1.05 \mathrm{E}-05 \\
& <1.03 \mathrm{E}-04 \\
& <4.10 \mathrm{E}-06 \\
& <1.48 \mathrm{E}-04 \\
& <8.40 \mathrm{E}-06 \\
& <7.62 \mathrm{E}-04
\end{aligned}
$$

2.59E-03

$6 \mathrm{E}-02$

$6.60 \mathrm{E}-05$

$3.77 \mathrm{E}-06$

$2.26 \mathrm{E}-03$

$1.27 \mathrm{E}-05$

1.71E-03

$2.83 \mathrm{E}-05$

$\mathrm{E}-05$

8.38E-03 
Table 5-6. $1995 \mathrm{PM}_{10}$ non-radiological air monitoring results for the 554th Range Squadron O\&M Complex (Concluded).

\begin{tabular}{llr}
\hline CompositePerid & Analyte \\
December & Arsenic & $<8.96 \mathrm{E}-03$ \\
& Barium & $<3.20 \mathrm{E}-01$ \\
& Beryllium & $<8.96 \mathrm{E}-04$ \\
& Cadmium & $<8.96 \mathrm{E}-04$ \\
& Lead & $<8.96 \mathrm{E}-03$ \\
& Manganese & $3.72 \mathrm{E}-03$ \\
& Molybdenum & $<1.79 \mathrm{E}-03$ \\
& Nickel & $<3.58 \mathrm{E}-03$ \\
& Silver & $<8.96 \mathrm{E}-04$ \\
& Thallium & $<1.79 \mathrm{E}-02$ \\
& Vanadium & $<8.96 \mathrm{E}-04$ \\
& Zinc & $<5.82 \mathrm{E}-02$
\end{tabular}

Note: $\mathrm{mg} / \mathrm{m}^{3}=$ milligrams per cubic meter. 
Table 5-7. $1995 \mathrm{PM}_{10}$ non-radiological air monitoring results for Station 14 (Continues).

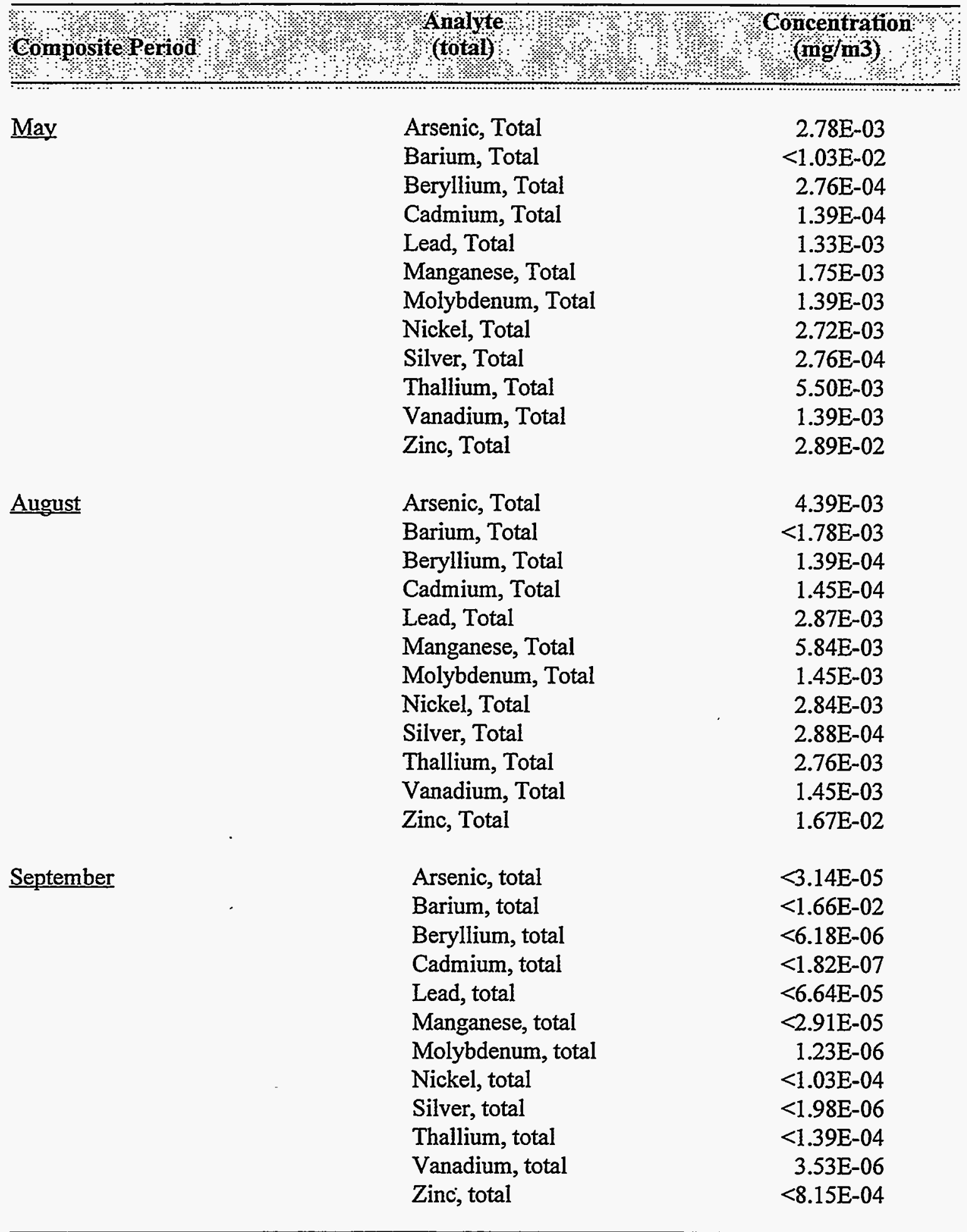


Table 5-7. $1995 \mathrm{PM}_{10}$ non-radiological air monitoring results for Station 14 (Concluded).

\section{October}

Composite Period

November

December
Analyte (totail)

\section{Concentration $(\mathrm{mg} / \mathrm{m} 3)$}

Arsenic, Total

Barium, Total

Beryllium, Total

Cadmium, Total

Lead, Total

Manganese, Total

Molybdenum, Total

Nickel, Total

Silver, Total

Thallium, Total

Vanadium, Total

Zinc, Total

Arsenic, Total

Barium, Total

Beryilium, Total

Cadmium, Total

Lead, Total

Manganese, Total

Molybdenum, Total

Nickel, Total

Silver, Total

Thallium, Total

Vanadium, Total

Zinc, Total

Arsenic, total

Barium, total

Beryllium, total

Cadmium, total

Lead, total

Manganese, total

Molybdenum, total

Nickel, total

Silver, total

Thallium, total

Vanadium, total

Zinc, total
$1.20 \mathrm{E}-03$

6.07E-02

6.63E-05

8.22E-06

$5.39 \mathrm{E}-03$

$2.46 \mathrm{E}-03$

$1.24 \mathrm{E}-05$

$1.19 \mathrm{E}-03$

5.19E-07

$<9.96 \mathrm{E}-05$

1.44E-05

9.95E-02

8.03E-04

$6.47 \mathrm{E}-02$

$<4.49 \mathrm{E}-06$

1.01E-06

$<4.92 \mathrm{E}-05$

1.34E-03

3.71E-04

$<8.54 \mathrm{E}-05$

$1.80 \mathrm{E}-04$

$1.69 \mathrm{E}-03$

$1.50 \mathrm{E}-05$

$1.99 \mathrm{E}-02$

$<6.99$ E-03

$<3.32 \mathrm{E}-01$

$<6.99$ E-04

$<6.99 \mathrm{E}-04$

$<6.99$ E-03

8.38E-04

$<1.40$ E-03

$<2.79 \mathrm{E}-03$

$<6.99 \mathrm{E}-04$

$<1.40 \mathrm{E}-02$

$<6.99 \mathrm{E}-04$

$<8.59 \mathrm{E}-02$

Note: $\mathrm{mg} / \mathrm{m}^{3}=$ milligrams per cubic meter. 
Table 5-8. $1995 \mathrm{PM}_{10}$ non-radiological air monitoring results for Well 6 (Continues).

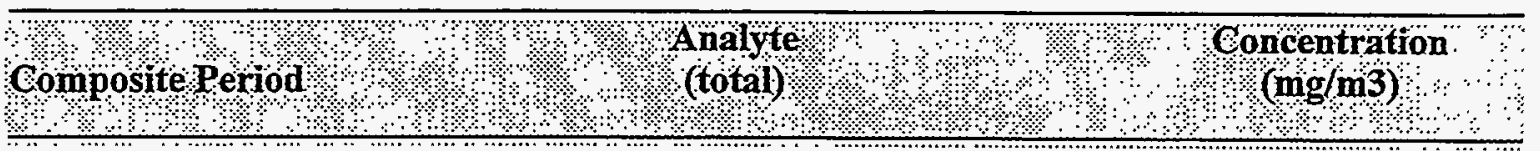

May

Arsenic, Total

Barium, Total

Beryllium, Total

Cadmium, Total

Lead, Total

Manganese, Total

Molybdenum, Total

Nickel, Total

Silver, Total

Thallium, Total

Vanadium, Total

Zinc, Total

Arsenic, Total

Barium, Total

Beryllium, Total

Cadmium, Total

Lead, Total

Manganese, Total

Molybdenum, Total

Nickel, Total

Silver, Total

Thallium, Total

Vanadium, Total

Zinc, Total

Arsenic, Total

Barium, Total

Beryllium, Total

Cadmium, Total

Lead, Total

Manganese, Total

Molybdenum, Total

Nickel, Total

Silver, Total

Thallium, Total

Vanadium, Total

Zinc, Total
2.71E-03

$<7.64 \mathrm{E}-03$

$5.46 \mathrm{E}-04$

$2.74 \mathrm{E}-04$

$5.46 \mathrm{E}-03$

$3.51 \mathrm{E}-03$

$2.74 \mathrm{E}-03$

$2.65 \mathrm{E}-03$

5.46E-04

8.13E-03

$2.74 \mathrm{E}-03$

$1.98 \mathrm{E}-02$

1.38E-03

$<1.88 \mathrm{E}-03$

1.35E-04

1.41E-04

2.79E-03

$1.78 \mathrm{E}-03$

$1.41 \mathrm{E}-03$

$2.76 \mathrm{E}-03$

$2.80 \mathrm{E}-04$

$2.68 \mathrm{E}-03$

$1.41 \mathrm{E}-03$

2.19E-02

$1.39 \mathrm{E}-03$

$<3.34 \mathrm{E}-03$

2.81E-04

1.41E-04

$1.35 \mathrm{E}-03$

$1.79 \mathrm{E}-03$

$1.42 \mathrm{E}-03$

$1.33 \mathrm{E}-03$

2.81E-04

$2.70 \mathrm{E}-03$

$1.42 \mathrm{E}-03$

2.72E-02 
Table 5-8. $\mathrm{PM}_{10}$ non-radiological air monitoring results for well 6 (Continues).

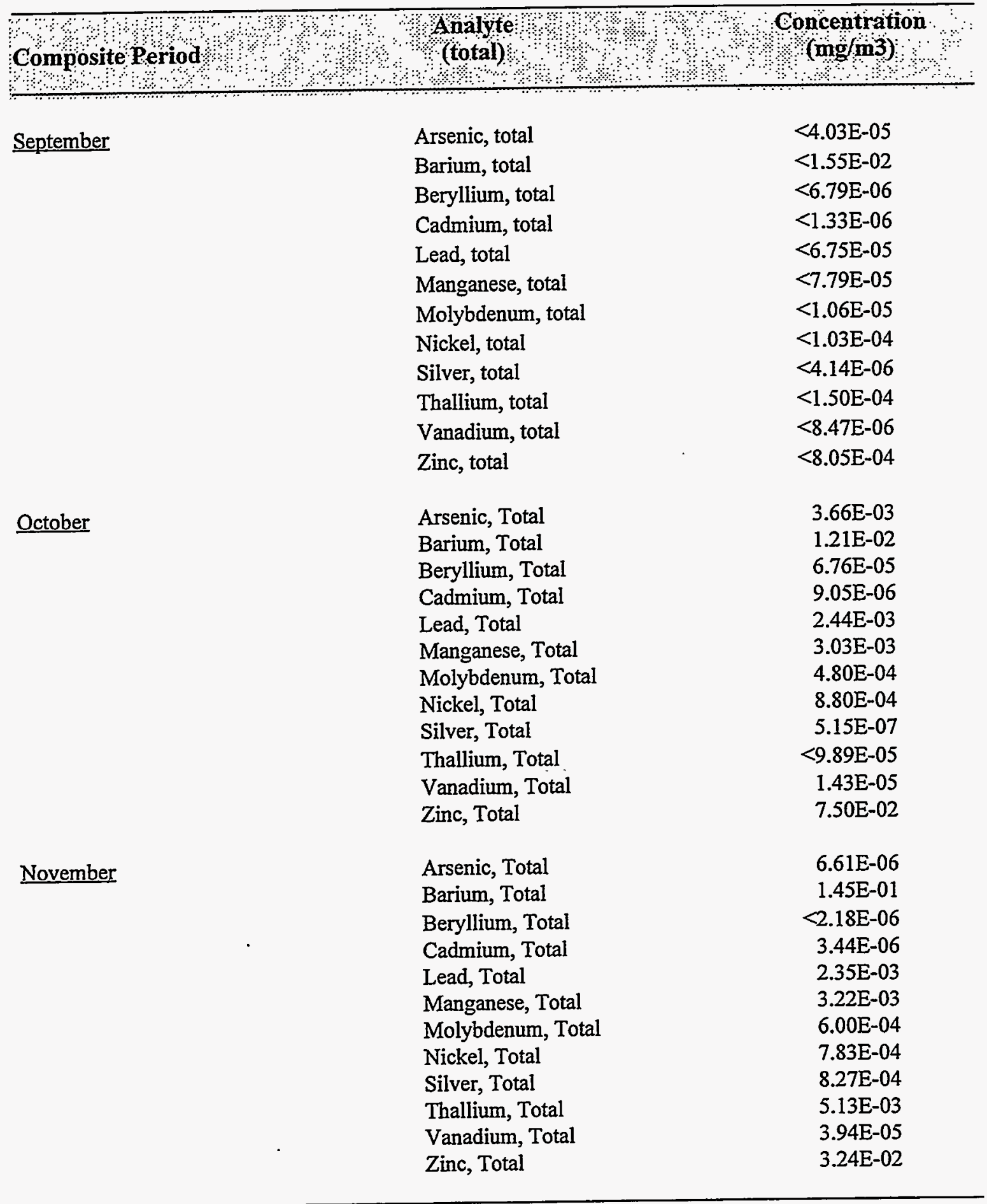


Table 5-8. $1995 \mathrm{PM}_{10}$ non-radiological air monitoring results for Well 6 (Concluded).

$\begin{array}{lll}\text { December } & \text { Arsenic, total } & <6.95 \mathrm{E}-03 \\ & \text { Barium, total } & <3.62 \mathrm{E}-01 \\ \text { Beryllium, total } & <6.95 \mathrm{E}-04 \\ \text { Cadmium, total } & <6.95 \mathrm{E}-04 \\ & \text { Lead, total } & <6.95 \mathrm{E}-03 \\ \text { Manganese, total } & 1.39 \mathrm{E}-04 \\ \text { Molybdenum, total } & <1.39 \mathrm{E}-03 \\ \text { Nickel, total } & <2.78 \mathrm{E}-03 \\ \text { Silver, total } & <6.95 \mathrm{E}-04 \\ \text { Thallium, total } & <1.39 \mathrm{E}-02 \\ \text { Vanadium, total } & <6.95 \mathrm{E}-04 \\ \text { Zinc, total } & <8.62 \mathrm{E}-02\end{array}$

Note: $\mathrm{mg} / \mathrm{m}^{3}=$ milligrams per cubic meter.

Evidence of water erosion has been observed within the outer control fence at Clean Slate 2. The erosive effects of water may pose another mechanism for transport of the contaminated material. Essington and Fowler (1976) observed the ability of $\mathrm{Pu}$ to migrate to deeper layers of soil with time. Vertical transport of contaminants into the soil column may allow greater exposure of roots and a potential for root uptake of contaminants by the plants. Soil profiles from the safety-shot areas at TTR indicate a decrease in the Pu-to-Am ratio with depth (Romney et al. 1975), suggesting greater vertical movement of Am-241 relative to Pu-239 and Pu-240. This same report also stated that there is evidence showing that Am is much more readily available to plants through roots than is Pu. Gilbert et al. (1975) stated that erosive processes and penetration into the soil would eventually flatten out peak contaminant concentrations, and that there was a need for long-term hazard evaluation to determine the change in contaminant concentrations over time at the safety-shot areas.

\subsection{KMI Services Monitoring Program}

KMI Services routine environmental monitoring activities at TTR include water and wastewater monitoring, operating air monitoring equipment for SNL and DOE/NV, radiological surveillance, soil sampling, management of the long-term environmental TLD network at TTR and adjacent off-site locations, and hazardous waste sampling. 
Environmental compliance permits for TTR include those for the potable water supply, sewage, and air quality. These permits are updated annually, or as necessary. Table A-2 of Appendix A shows the current permit list.

In addition, KMI Services assists SNL in meeting two other annual requirements: the SARA, Title III (the Emergency Planning and Community Right-to-Know Act [EPCRA]), reporting requirements for all TTR activities and the State of Nevada extremely hazardous material reporting requirements.

\subsubsection{Water}

Using preserved sample bottles supplied by a state-certified laboratory, KMI Services staff collected water samples quarterly from the Well 6 distribution system that services Technical Area 3 (TA-3) and transported the samples to the laboratory in Las Vegas, NV for bacteriological analysis (Table 5-9). All analyses met the requirements of the total coliform rule. Monthly samples were collected in 1995.

Table 5-9 summarizes water sampling of the public water systems at TTR and the frequency and type of analysis and results. Waste water is sampled quarterly by the U.S. Air Force (USAF) at the headwater end of the facultative sewage lagoon (Table 5-10).

Well 6 is also sampled by the EPA to provide a radiological analysis survey for the LongTerm Hydrologic Monitoring Program. Sampling sites are based on the Tonopah Test Range Site Sampling Plan (DOE 1990) for compliance with the Safe Drinking Water Act.

Table 5-9. Summary of 1995 SNL/NV public water systems sampling.

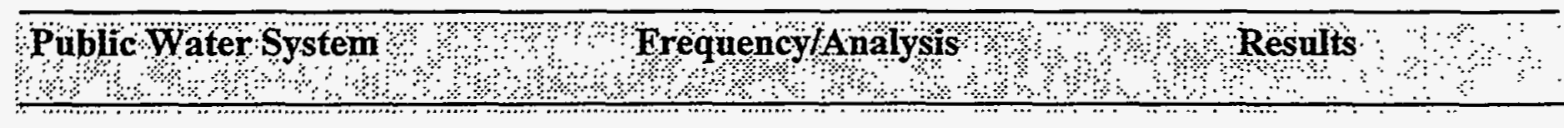

NY3014 $12^{*}$

Monthly/bacteriologic, total coliform
All analyses were negative for coliform.

TTR Well 6. 
Table 5-10. Summary of 1995 SNL/NV wastewater sampling program.

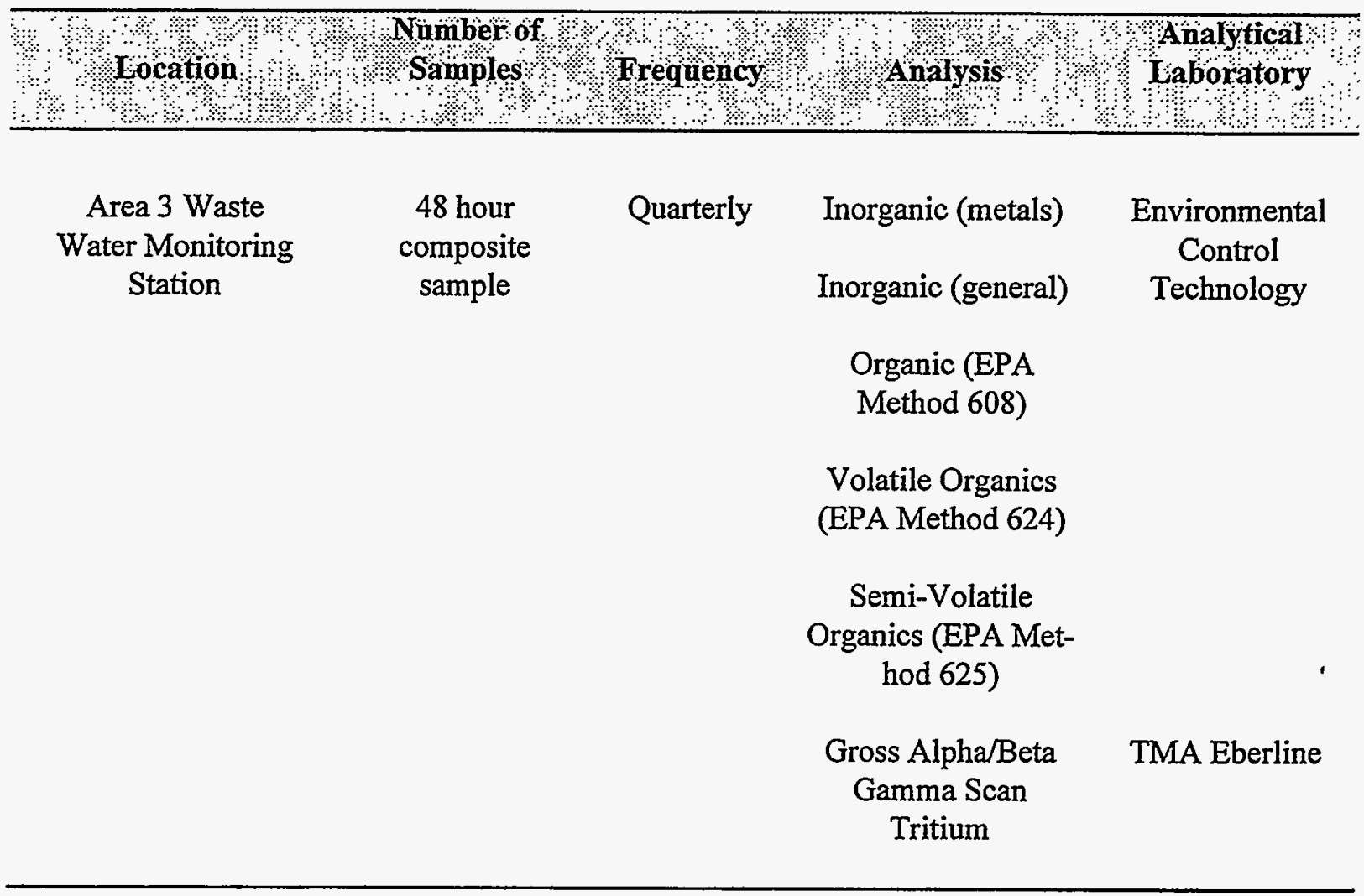

The permit for Well 6 is renewed annually by the State of Nevada Bureau of Health Protection Services. Permit updates are obtained annually DOE/KAO and copies are forwarded to SNL/NV.

\subsubsection{Sewage System}

Sewage from SNL facilities at TA-3 of TTR goes to the USAF facultative sewage lagoon. The NDPES permit was held by DOE/NV through July 1992 when it was transferred to the USAF Nellis Air Force Base (NAFB) Range Complex. The sewage from locations in remote areas flows into septic tanks and associated drain fields. These discharges fall primarily under the statutory authority of the Clean Water Act (CWA) and the Safe Drinking Water Act (SDWA) as amended. These discharges are regulated under Nevada Administrative Code, Chapters 444-445 (Appendix A, Table A-1), and are administered by the State of Nevada, Bureau of Health Protection Services, and the NDEP. The wastewater samples from the headworks and sewage lagoons are analyzed quarterly for biochemical oxygen demand (BODs), TPH, VOCs, and RCRA 8 metals. Additionally, flow into the lagoon is limited to a 30-day average of 30,000 gal per day, with a daily maximum of 75,000 gal per day. Quarterly Discharge Monitoring Reports (DMRs) are prepared and submitted by the USAF to the Nevada Division of Environmental 


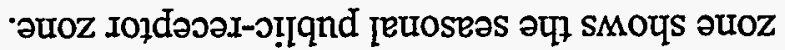

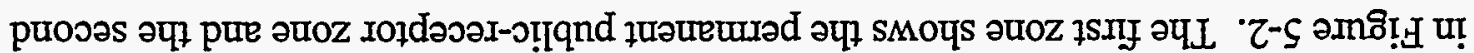

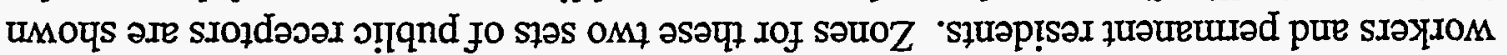

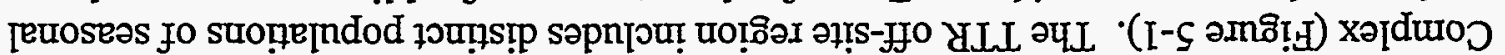

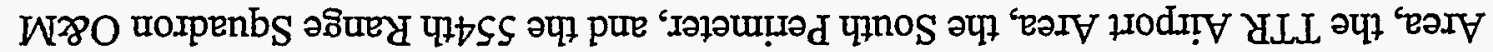

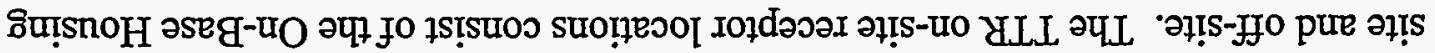

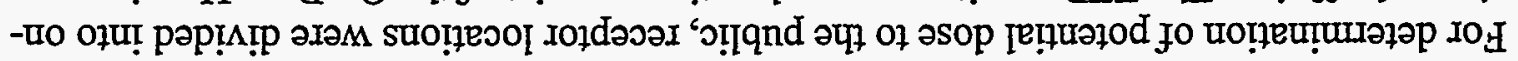

\section{suo!̣eo07 Jozdəoəy $1 \cdot 9 \cdot 9$}

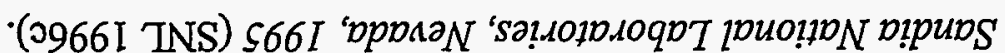

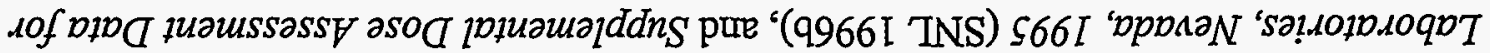

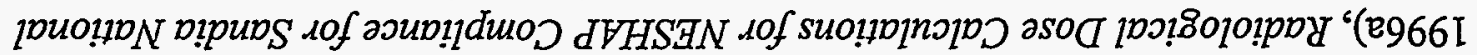

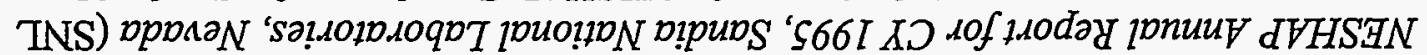

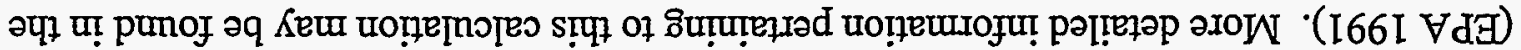

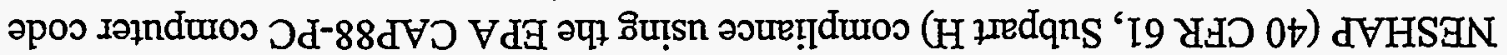

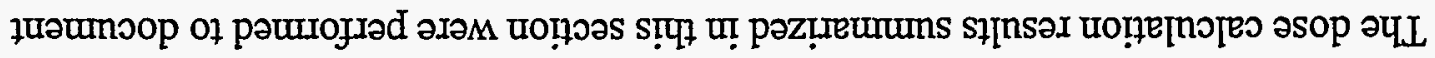

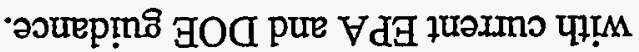

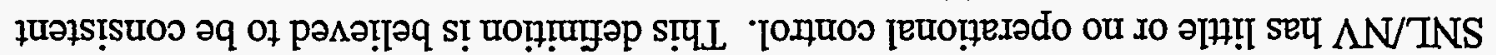

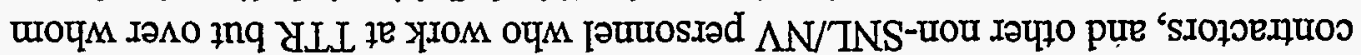

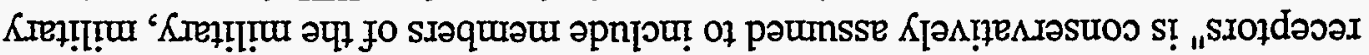

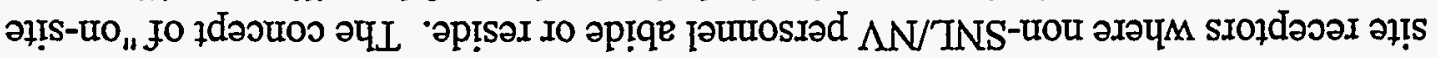

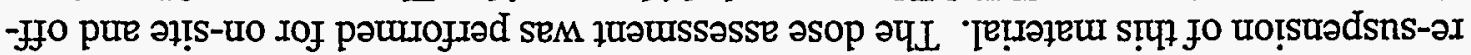

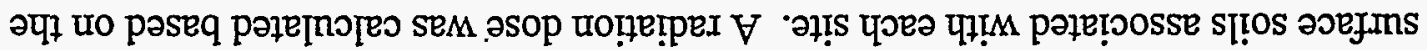

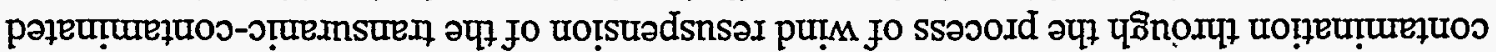

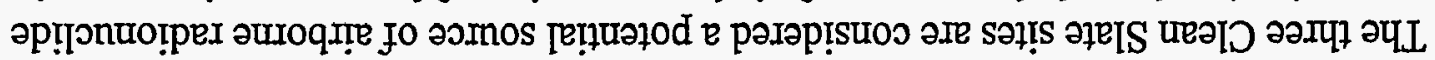

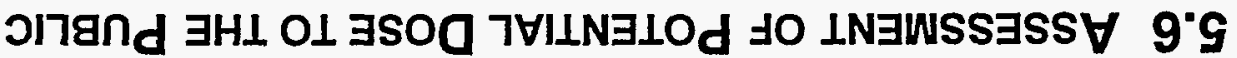

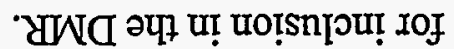

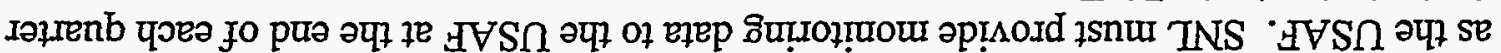

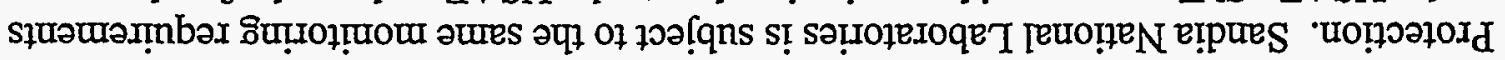




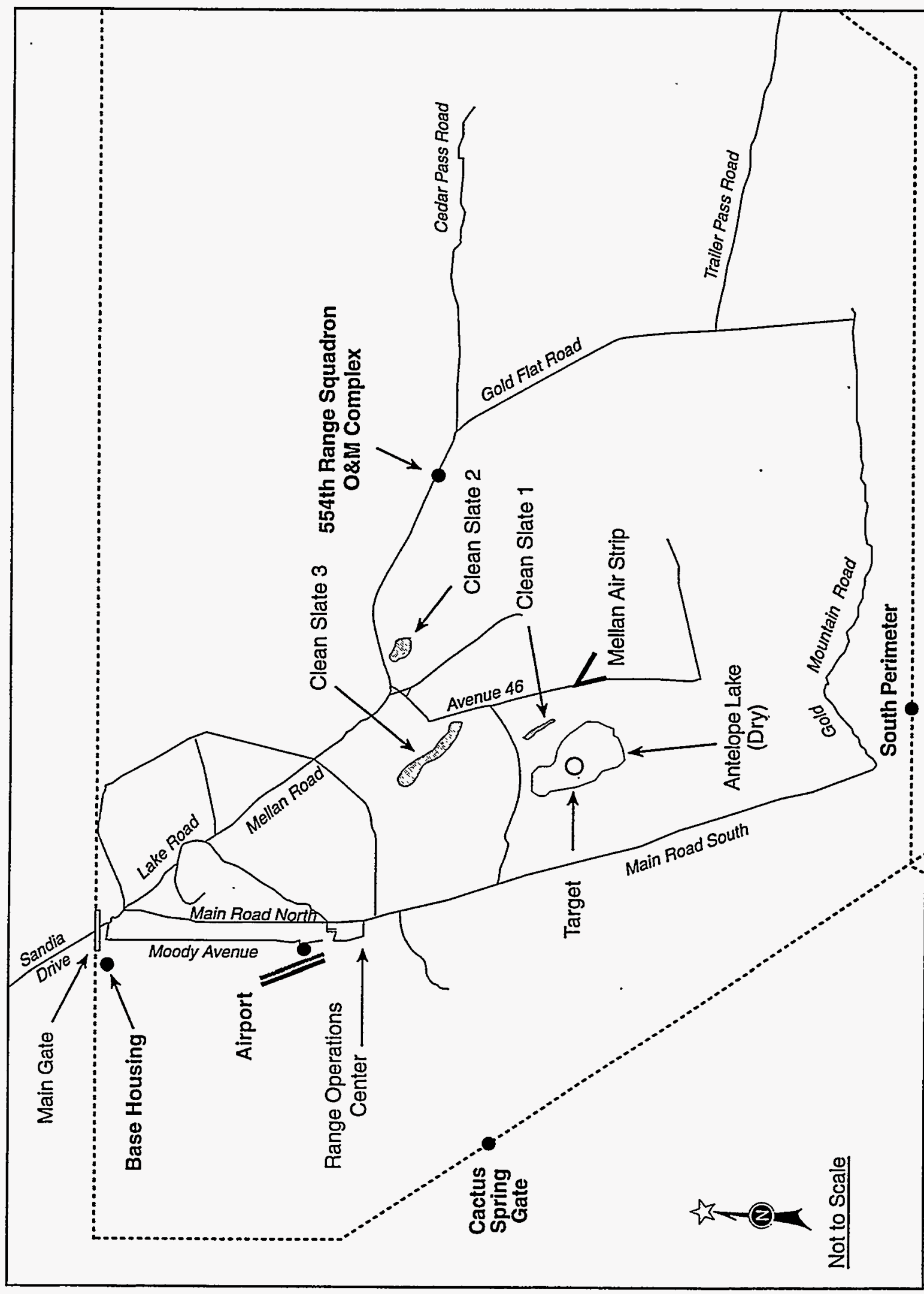

 


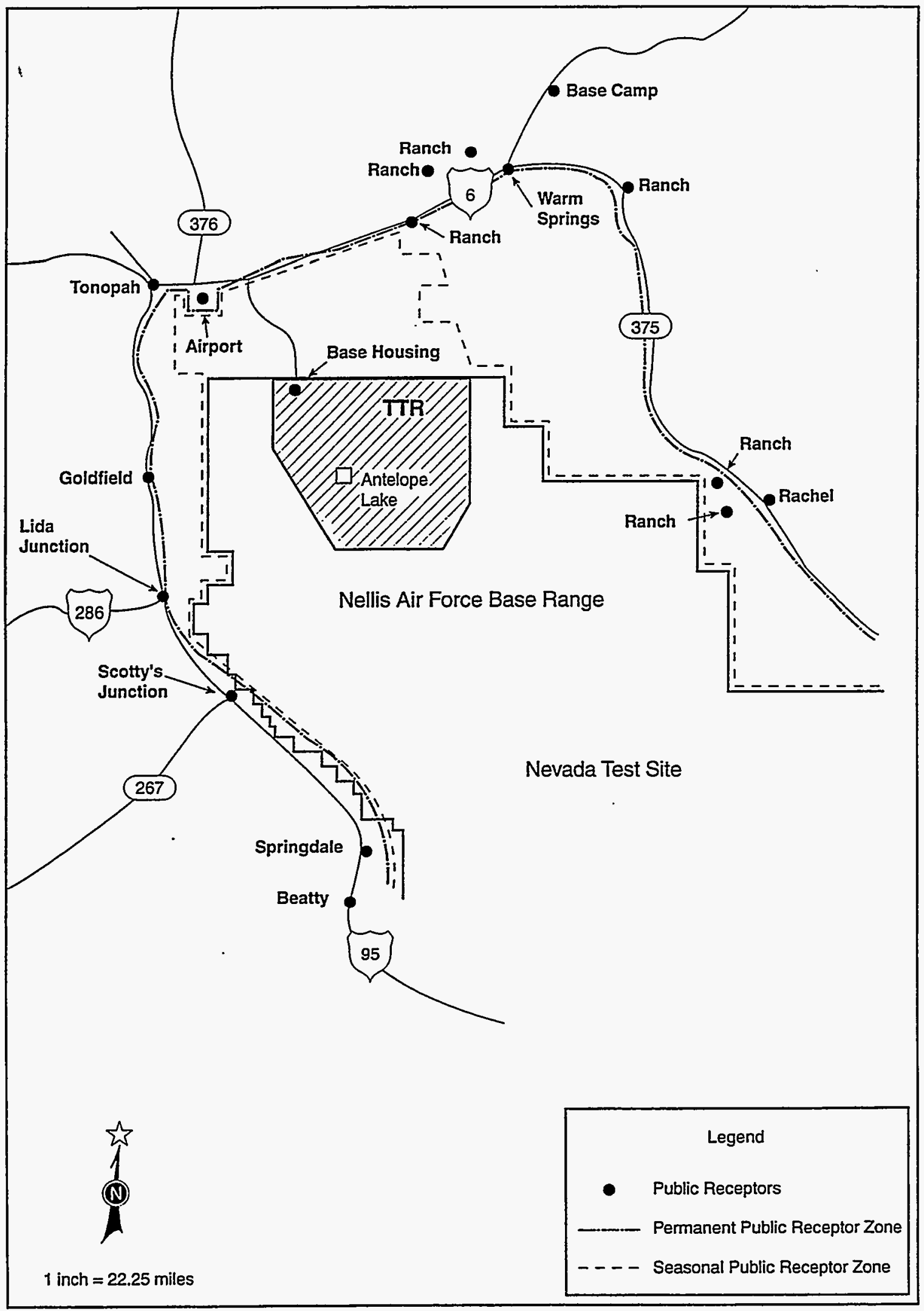

Figure 5-2. Public receptor zone around the Tonopah Test Range. 


\subsubsection{Meteorological Data}

A composite meteorological data set for the TTR area was developed based on information from two sources: Tonopah Municipal Airport and on-site at TTR. The Tonopah Municipal Airport is located approximately $65 \mathrm{~km}$ north of TTR (DOC 1994) and an on-site meteorological station is located in the northern portion of TTR (DOC 1993). The composite data set includes hourly meteorological observations of wind direction, wind speed, and stability class (inferred from wind and solar insolence).

\subsubsection{Release Sources}

During 1995, no radiological point-source releases occurred as a result of TTR operations. The potential releases associated with the Clean Slate sites occur as a result of the wind re-suspension of soil particulates (fugitive dust) contaminated with transuranic radionuclides. The 1977 EG\&G aerial radiological survey of Clean Slates 1, 2 , and 3 documented the level of residual surface-soil activity in the form of radiation isopleths showing the soil activity of Am-241, Pu-239, and Pu-240 (EG\&G 1979b). The study concluded that the contaminated area associated with the Clean Slate sites is approximately 20 million square meters.

The annual diffuse source term associated with the Clean Slate sites was calculated using a wind resuspension model which calculates the rate at which soil particulates become airborne. This model uses site-specific information (e.g., wind speed, wind direction, and contaminant source term) whenever appropriate.

A release of 0.39 curies per year ( $\mathrm{Ci} / \mathrm{yr})$ of total activity $(\mathrm{Pu}-238, \mathrm{Pu}-239, \mathrm{Pu}-240, \mathrm{Pu}-$ 241, $\mathrm{Pu}-242$, and $\mathrm{Am}-241$ ) was calculated as the re-suspended source term associated with the Clean Slate sites. This re-suspended source term is for particulate matter which is $10 \mu \mathrm{m}$ or less in diameter, and is assumed to be entirely respirable.

\subsubsection{Radiological Dose Assessment}

The diffuse emissions associated with the three Clean Slate sites were the focus of the dose assessment because there were no point-source radionuclide emissions. The regional population dose was calculated to be 0.90 person-rem per year (person-rem/yr). The dose to the MEI was calculated to be $1.1 \mathrm{mrem} / \mathrm{yr}$. The MEI is located at the TTR Airport Area. The MEI dose is a factor of approximately eight below the NESHAP dose standard of $10 \mathrm{mrem} / \mathrm{yr}$. 


\subsection{REFERENCES}

Culp 1994: Culp, T., "Department 7575 Technical Operating Procedure for Validation and Analysis of Environmental Surveillance Data," TOP-94-07, Sandia National Laboratories, Albuquerque, NM (1994).

Culp and Howard 1994: Culp, T., and D. Howard, "1993 Site Environmental Monitoring Report, Tonopah Test Range, Tonopah, Nevada," SAND94-1293, Sandia National Laboratories, Albuquerque, NM (1993).

DOC 1993: U.S. Department of Commerce, "Weather Service Nuclear Support Office Meteorological Data for the Tonopah Test Range, 1989-1992," National Weather Service, Western Region, Las Vegas, NV (1193)."

DOC 1994: U.S. Department of Commerce, "NOAA (National Oceanic and Atmospheric Administration) Environmental Data Service, monthly and annual distribution by Pasquill Stability Classes, STAR Program, Tonopah, NV," National Climatic Center (NCC) Federal Building, Ashville, NC (1993).

DOC 1991: U.S. Department of Commerce, Bureau of the Census, "1990 United States Census," DOC, U.S. Government Printing Office, Washington, DC (1991).

DOE 1995: U.S. Department of Energy, "Voluntary Corrective Action Work Plan."

DOE 1994: U.S. Department of Energy, "Draft Resource Conservation and Recovery Act Facility Investigation Work Plan," DOE/NV, Las Vegas, NV (1994).

DOE 1992: U.S. Department of Energy, "Water Conservation Plan for the Tonopah Test Range," R4809, DOE/NV, Las Vegas, NV (1992).

DOE 1990: U.S. Department of Energy, "Tonopah Test Range Site Sampling Plan," DOE/NV, Las Vegas, NV (1990).

DOE 1988: (See Orders section)

Eckerman et al. 1988: Eckerman, K. F., A. B. Wolbarst, and A. C. B. Richardson, "Limiting Values of Radionuclide Intake and Air Concentration and Dose Conversion Factors for Inhalation, Submersion, and Ingestion," Federal Guidance Report No. 11, EPA-520/1-88-020, Office of Radiation Programs, U.S. Environmental Protection Agency, Washington, DC (1988). 
EG\&G 1994: Edgerton, Germeshausen \& Grier Corporation, "A Multispectral Scanner Survey of the Tonopah Test Range," EG\&G11265-109, Las Vegas, NV (1994).

EG\&G 1979a: Edgerton, Germeshausen \& Grier Corporation, "Status of Endangered and Threatened Species on Test Range - A Survey," EGG-1183-2387, EG\&G, Las Vegas, NV (1979).

EG\&G 1979b: Edgerton, Germeshausen \& Grier Corporation, "An Aerial Radiological Survey of Clean Slates 1, 2, and 3, and Double Track, Test Range," EGG-1183-1737, Energy Measurement Group, EG\&G, Las Vegas, NV (1979).

EPA 1994: U.S. Environmental Protection Agency, Region III, "Risk-Based Concentration Table, Fourth Quarter 1994," Technical Support Section (3HW13), 841 Chestnut Street, Philadelphia, PA (November 8, 1994).

EPA 1991: U.S. Environmental Protection Agency, "CAP-88, Clean Air Act Assessment Package," Radiation Shielding Information Center, CCC-542, Oak Ridge, TN (1991).

ERDA 1975: U.S. Energy Research and Development Administration, "Environmental Assessment, Tonopah Test Range," EIA/MA/76-2, ERDA (1975).

Essington and Fowler 1976: Essington, E. H., and E. B. Fowler, 'Distribution of Transuranic Nuclides in Soils: A Review,' in "Transuranics in Natural Environments," Report NVO-178 (1976).

Gilbert et al. 1975: Gilbert, R. O., et al., 'Statistical Analysis of ${ }^{239-240} \mathrm{Pu}$ and ${ }^{241} \mathrm{Am}$ Contamination of Soil and Vegetation on NAEG Study Sites,' in "The Radioecology of Plutonium and Other Transuranics in Desert Environments," Report NVO-153, Battelle Memorial Institute, Pacific Northwest Laboratory, Richland, WA (1975).

IT 1994a: IT Corporation, "Draft Initial Surface Geophysical Survey Report for the Tonopah Test Range Environmental Restoration Sites," DOE/NV/10972-93, IT, Las Vegas, NV (1994).

IT 1994b: IT Corporation, "Draft Tonopah Test Range Site Priority Ranking Model," IT, Las Vegas, NV (1994).

IT 1994c: IT Corporation, "Voluntary Corrective Action Work Plan for Ordnance Removal from Five Disposal Sites at the Tonopah Test Range," DOE/NV-386, IT, Las Vegas, NV (1994). 
IT 1993: IT Corporation, "Analytical Results for Tonopah Test Range, Transformer Oil Samples, Collected July 16-18, 1993," IT, Albuquerque, NM (September 1993).

Leavitt 1980: Leavitt, V., "Soil Profiles of Mounds on Plutonium-Contaminated Areas of the Nevada Test Range Complex," Environmental Monitoring Systems Laboratory, U.S. Environmental Protection Agency, Las Vegas, NV (1980).

Leavitt 1976: Leavitt, V., 'Soil Surveys of Five Plutonium-Contaminated Areas on the Test Range Complex in Nevada,' in "Nevada Applied Ecology Group Procedures Handbook for Environmental Transuranics," Report NVO-166, National Environmental Research Center, Las Vegas, NV (1976).

Rarrick 1993: Rarrick, H., Personal communication with Todd Culp (February 2, 1993).

Romney et al. 1975: Romney, E. M., et al., ${ }^{239-240} \mathrm{Pu}$ and ${ }^{241} \mathrm{Am}$ Contamination of Vegetation in Aged Plutonium Fallout Areas,' in "The Radioecology of Plutonium and Other Transuranics in Desert Environments," Report NVO-153, Laboratory of Nuclear Medicine and Radiation Biology, University of California, Los Angeles, CA (1975).

Schaeffer 1982: Schaeffer, J. R., "Climatology of the Tonopah Test Range, 1967," SC-M-68-522, Sandia National Laboratories, Albuquerque, NM (1982).

Secretary of Energy 1990. "National Environmental Policy Act Notice," SEN-15-90, February 5, 1990.

SEN-15-90, see Secretary of Energy.

Sinnock 1982: Sinnock, S., "Geology of the Nevada Test Site and Nearby Areas - Southern Nevada," SAND82-2207, Sandia National Laboratories, Albuquerque, NM (1982).

SNL 1996a: Sandia National Laboratories, "NESHAP Annual Report for CY 1995," in preparation. Sandia National Laboratories, Albuquerque, NM (1996).

SNL 1996b: Sandia National Laboratories, "Radiological Dose Calculations for NESHAP Compliance for Sandia National Laboratories, Nevada, 1995," Sandia National Laboratories, Albuquerque, NM (1996). 
SNL 1996c: Sandia National Laboratories, "Supplemental Dose Assessment Data for Sandia National Laboratories, Nevada, 1995," Sandia National Laboratories, Albuquerque, NM (1996).

SNL 1995a: Sandia National Laboratories, "NESHAP Annual Report for CY 1994, Sandia National Laboratories, Nevada," Sandia National Laboratories, Albuquerque, NM (June 1995).

SNL 1995b: Sandia National Laboratories, "Radiological Dose Calculations for NESHAP Compliance for Sandia National Laboratories, Nevada, 1994," Sandia National Laboratories, Albuquerque, NM (1995).

SNL 1995c: Sandia National Laboratories, "Supplemental Dose Assessment Data for Sandia National Laboratories, Nevada, 1994," Sandia National Laboratories, Albuquerque, NM (1995).

SNL 1994: Sandia National Laboratories, "Spill Prevention Control and Countermeasure (SPCC) Plan," Plan 90-11, updated June 1994, Sandia National Laboratories, Albuquerque, NM (1994).

SNL 1992a: Sandia National Laboratories, "Environmental Monitoring Plan for the Tonopah Test Range, Nevada," Sandia National Laboratories, Albuquerque, NM (1992).

SNL 1992b: Sandia National Laboratories, "Environmental Sampling Procedure," SP471991, Sandia National Laboratories, Albuquerque, NM (November 19, 1992).

SNL 1991: Sandia National Laboratories, "National Environmental Policy Act (NEPA) Program," PG470110, Sandia National Laboratories, Albuquerque, NM (1991).

SNL 1990: Sandia National Laboratories, "Spill Prevention Control and Countermeasure (SPCC) Plan," Plan 90-11, Sandia National Laboratories, Albuquerque, NM (1990).

TTR 1992: Tonopah Test Range, "Environmental Monitoring Reports, Tonopah Test Range," Volumes 1 through 4, TTR, Tonopah, NV (1992).

Tamura 1977: Tamura, T., 'Plutonium Distribution in a Desert Pavement Desert Mound,' in "Environmental Plutonium on the Nevada Test Site and Environs," Report NVO-171, Oak Ridge National Laboratory, Environmental Sciences Division, Oak Ridge, TN (1977). 


\section{\%}
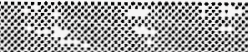

Tamura 1976: Tamura, T., 'Plutonium Association in Soils,' in "Transuranics in Natural Environments," Report NVO-178, Oak Ridge National Laboratory, Environmental Sciences Division, Oak Ridge, TN (1976).

Tamura 1975: Tamura, T., 'Characterization of Plutonium in Surface Soils from Area 13 of the Nevada Test Site,' in "The Radioecology of Plutonium and Other Transuranics in Desert Environments," Report NVO-153, Oak Ridge National Laboratory, Environmental Sciences Division, Oak Ridge, TN (1975).

Tamura 1974: Tamura, T., 'The Dynamics of Plutonium in Desert Environments, Nevada Applied Ecology Group Report,' in "Distribution and Characterization of Plutonium in Soils from Nevada Test Site," Report NVO-142 (1974). 


\section{AcTs}

American Indian Religious Freedom Act (AIRFA) of 1978, as amended. Title 42 U.S.C. 1996.

Archaeological Resources Protection Act (ARPA) of 1979, Public Law 96-95, as amended by Public Law 100-588.

Clean Air Act (CAA) of 1955, as amended. Title 42 U.S.C. 7401.

Clean Water Act (CWA) of 1948, (Federal Water Pollution Control Act), as amended. Title 33 U.S.C. 1251.

Comprehensive Environmental Response, Compensation and Liability Act (CERCLA) of 1980 , as amended. Title 40 U.S.C. 9601.

Emergency Planning and Community Right-to-Know Act of 1986 (EPCRA) (Enacted by Public Law 99-499, October 17, 1986; 42 U.S.C. 11001 et seq.).

Endangered Species Act (ESA) of 1973, as amended. Title 16 U.S.C. 1531.

Federal Insecticide, Fungicide, and Rodenticide Act (FIFRA), as amended. Title 7 U.S.C. 136.

National Environmental Policy Act (NEPA) of 1969, as amended. Title 42 U.S.C. 4341.

National Historic Preservation Act (NHPA) of 1966, as amended. Title 16 U.S.C. 470.

Resource Conservation and Recovery Act (RCRA) of 1976. Public Law 94-580, 1976, 90 Statute 2795.

Safe Drinking Water Act (SDWA) of 1974, as amended. Title 42 U.S.C. $\S 300 f$ et seq.

Superfund Amendments and Reauthorization Act (SARA) of 1986. Title III, Section 313, "Toxic Chemical Release Reporting."

Toxic Substances Control Act (TSCA) of 1976. Title 15 U.S.C. 2601. 


\section{Code of Federal Regulations}

10 CFR 1021, 1992. "National Environmental Policy Act Implementing Procedures," as revised April 24, 1992.

40 CFR 61, 1973. "National Emission Standards for Hazardous Air Pollutants (NESHAP)," including 1985, Subpart H, "National Emission Standards for Emissions of Radionuclide Other Than Radon From Department of Energy Facilities," as amended.

40 CFR 112, 1973. "Oil Pollution Prevention," as amended March 26, 1976.

40 CFR 141.26, 1992. "Monitoring Frequency for Radioactivity in Community Water Systems" (Revision 6, September 15, 1992).

40 CFR 270.61. "EPA Administered Permit Programs: The Hazardous Waste Permit Program. 


\section{ORDERS}

DOE 1988: U.S. Department of Energy, "General Environmental Protection Program," DOE Order 5400.1, DOE, Washington, DC (1988, change 1, June 21, 1990).

Executive Order 11988, Floodplain Management (Signed May 24, 1977; 42 FR 26951, 3 CFR, 1977 Comp., p. 117; Amended by Executive Order 12148, July 20, 1979; 44 FR 43239, 3 CFR, 1979 Comp., p. 412).

Executive Order 11990, Protection of Wetlands (Signed May 24, 1977; 42 FR 26961, 3 CFR, 1977 Comp., p. 121). 
APPENDIX A

STATE OF NEVADA REGULATIONS AND PERMIT LISTINGS 
This page intentionally blank 


\section{CONTENTS}

TABLES

Page

A-1 State of Nevada Regulations Applicable to the Tonopah

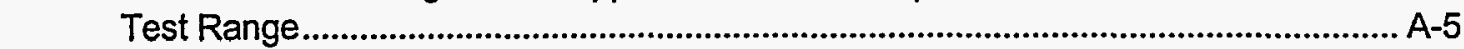

A-2 Tonopah Test Range Permits and Registrations ................................................... A-8 
1995 SITE ENVIRONMENTAL REPORT

TONOPAH TEST RANGE, TONOPAH, NEVADA

This page intentionally blank

A-4 
Table A-1. State of Nevada Regulations Applicable to the Tonopah Test Range.

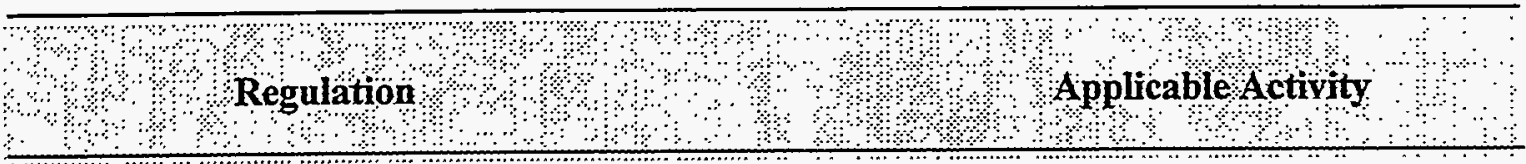

\section{Nevada Wildlife Regulations}

Nevada Revised Statute, Title 45, Chapter 501.

NRS 501.010-501.243

Wildlife Regulations

NAC 504.510-504.550

Nevada Air Quality Regulations

Nevada Revised Statutes, Title 40, Public Health and Safety, Chapter 445. NRS 445.401-445.601

NAC $445.430-445.995$

Nevada Water Pollution

Nevada Revised Statutes, Title 40, Public Health and Safety, Chapter 445. NRS 445.131-445.354
- Diversion of surface drainage channels

- Clearing, leveling, and grading of site

- Road construction

- Highway improvement

- Installation of water lines

- Installation of water reservoirs

- Installation of fuel storage tanks

- Construction of sanitary landfill

- Construction of explosives bunkers

- Diversion of surface drainage channels

- Clearing, leveling, and grading of site

- Road construction

- Highway improvement

- Installation of water lines

- Installation of water reservoirs

- Installation of fuel storage tanks

- Construction of sanitary landfill

- Construction of explosives bunkers

- Construction of support buildings

- Incinerator

- Diesel-powered emergency generator

- Construction of operation of Control Regulations sewage treatment plant

- Disposal of drilling fluids

- Water treatment plant

NAC 445.070-445.194 
Table A-1. State of Nevada Regulations Applicable to the Tonopah Test Range (Continued).

Nevada Regulations

Solid Waste Management

Nevada Revised Statutes, Title 40, Public Health and Safety, Chapter 444.

NRS 444.510-444.610

Regulations Governing Solid Waste Management

Nevada Regulations

Governing Individual

Sewage Systems

Nevada Revised Statutes, Title 40, Public Health and Safety, Chapter 444. NRS 444.650

NAC $444.750-444.840$

Nevada Public Water Supply and Public Water Systems Regulations

Nevada Revised Statutes, Title 40, Public Health and Safety, Chapter 445.

NRS 445.030

NAC $445.370-445.420$
- Clearing, leveling, and grading of site

- Construction of support buildings

- Construction and operation of sanitary landfill

- Daily sanitary wastes

- Disposal of sewage sludge

- Construction of sewage collection systems
- Installation of water lines

- Installation of water reservoirs 
Table A-1. State of Nevada Regulations Applicable to the Tonopah Test Range (Concluded).

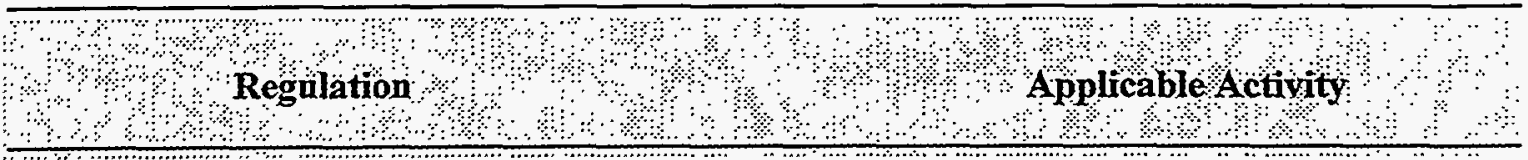

Nevada Water Resources

Nevada Revised Statutes, Underground Water and Wells, Chapters 533 and 534.

NRS 534.010-534.190

Regulations for Drilling Wells

\section{Radiation Control}

Nevada Revised Statutes, Title 40, Public Health and Safety, Chapter 459. NRS 459.010-459.290

Nevada Regulations for Radiation Control
- Installation of water lines

- Installation of water reservoirs

- Use of radioactive sources 
Table A-2. Tonopah Test Range Permits and Registrations.

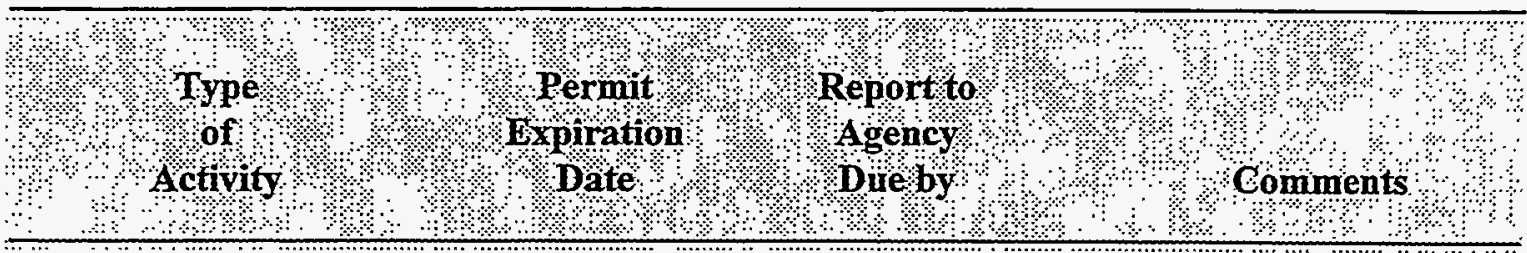

Air Quality *

1. Petro Storage

JP-4

2. Petro Storage

JP-4

3. Petro Storage

$\mathrm{JP}-4$

4. Petro Storage

$\mathrm{JP}-4$

5. Petro Storage

Diesel \#1

6. Petro Storage

Diesel \#1

7. Large Batch

Plant (Ross)
$09 / 15 / 97$

$03 / 26 / 97$

$03 / 26 / 97$

$03 / 26 / 97$

$03 / 26 / 97$

09/15/93

(in process of

being renewed)

$02 / 12 / 96$
State of Nevada (NV) to

U.S. Air Force (USAF)

Permit \#2449

State of NV to USAF

Permit \#2448

State of NV to USAF

Permit \#2447

State of NV to USAF

Permit \#2446

State of NV to USAF

Permit \#2445

State of NV to USAF

Permit \#1661

$04 / 15 / 93 \dagger$
State of NV to U.S. Department of Energy/ Nevada Operations Office (DOE/NV) Permit \#2229

\footnotetext{
*Air Quality Activities 1 to 6 apply to the surface tanks in Technical Area 10 (Industrial Area).

†Annual Summary Report transmitted through the DOE/NV/Environmental Programs Departments (EPD) Office to Nevada Division of Environmental Protection. ¥National Pollutant Discharge Elimination System (NPDES) permit renewal application has been transmitted to the State of Nevada. The State is presently renewing the application and design modification. Expected renewal date is unknown.
} 
Table A-2. Tonopah Test Range Permits and Registrations (Continued).

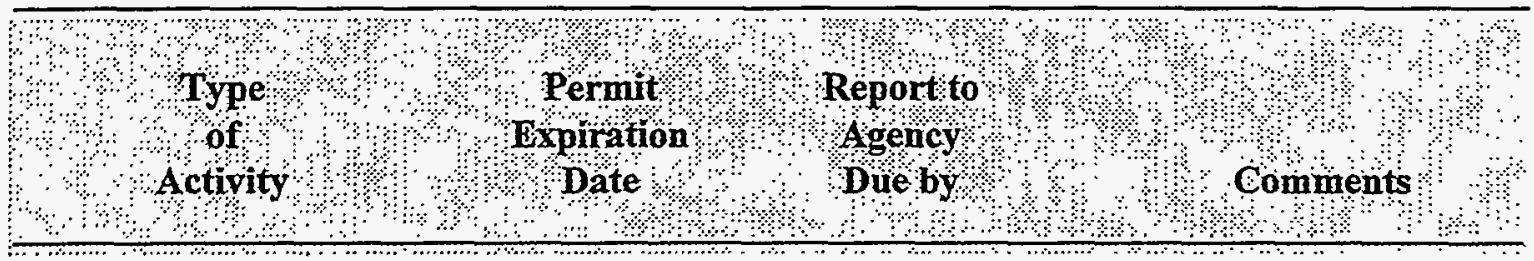

8. Small Batch Plant $\quad 02 / 19 / 96$

(S. C. Johnson)

$04 / 15 / 93+$

9. Crusher

Cedarapids Mdl \#2416

10. Crusher

Cedarapids Mdl \#1524

11. Screen

Cedarapids Mdl \#2416

12. Surface

Disturbance

13. Incinerator

(MDL 500CA)

14. Vapor Extraction (Fire Training Pit)
04/15/93†

State of NV to DOE/NV

Permit \#2231

State of NV to DOE/NV

Permit to Operate $\$ 2456$

04/15/93† State of NV to DOE/NV

Permit to Operate \#2457

04/15/93† State of NV to DOE/NV

Permit to Operate \#2455

04/15/93†

State of NV to DOE/Kirtland Area Office (DOE/KAO)

Air Quality Permit \#2844

04/15/93†

State of NV to USAF

Permit \#2450

State of NV to USAF

Air Quality Permit

\#AP9999-0547

\footnotetext{
*Air Quality Activities 1 to 6 apply to the surface tanks in Technical Area 10 (Industrial Area).

†Annual Summary Report transmitted through the DOE/NV/Environmental Programs Departments (EPD) Office to Nevada Division of Environmental Protection.

$\ddagger$ National Pollutant Discharge Elimination System (NPDES) permit renewal application has been transmitted to the State of Nevada. The State is presently renewing the application and design modification. Expected renewal date is unknown.
} 
Table A-2. Tonopah Test Range Permits and Registrations (Concluded).

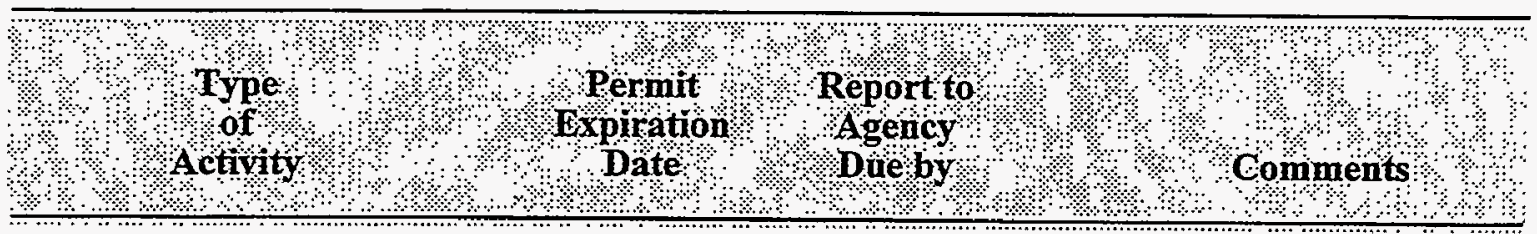

Water Systems
1. Mancamp Area
Well IA
$09 / 30 / 95$
Monthly
State of NV to USAF
Permit \#NY-4068-12C
Bureau of Land
Management (BLM) Well
2. Industrial Area
Well 3A
Well EH-2
$09 / 30 / 95$
Monthly
State of NV to USAF
Permit \#NY-5001-12NC
3. SNL Compound
$09 / 30 / 95$
Monthly
State of NV to DOE/KAO
Permit \#NY-3014-12NC
4. Tonopah Electric
09/30/95
Monthly
State of NV to USAF
Permit \#NY-5002-12NC
Combat Range (TECR)
(Operations and
Maintenance [O\&M]) Well

Sewage System

1. Tonopah Integrated

Air Defense System

08/20/92 $\quad$ Quarterly

State of NV to USAF

(TIADS) Mancamp

Permit \#NEV20001

Industrial Area

Hazardous Waste

1. EPA Waste ID

N/A Yearly

EPA to DOE/KAO

Number TTR

EPA I.D. \#NV1890011991

\footnotetext{
*Air Quality Activities 1 to 6 apply to the surface tanks in Technical Area 10 (Industrial Area).

†Annual Summary Report transmitted through the DOE/NV/Environmental Programs

Departments (EPD) Office to Nevada Division of Environmental Protection.

$¥$ National Pollutant Discharge Elimination System (NPDES) permit renewal application has been transmitted to the State of Nevada. The State is presently renewing the application and design modification. Expected renewal date is unknown.
} 


\section{APPENDIX B}

\section{RADIOLOGICAL SAMPLING LOCATIONS}

AND RESULTS 


\section{CONTENTS}

FIGURES

Page

B-1 Off-Site Soil Sampling Locations ......................................................................... B-5

B-2 Perimeter Soil Sampling Locations........................................................................... B-7

B-3 Soil Sampling Locations Near the On-Base

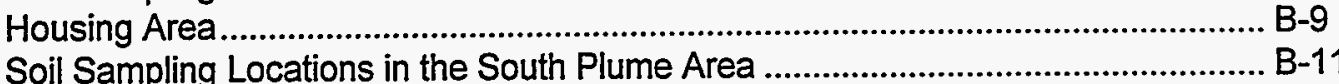

B-4 Soil Sampling Locations in the South Plume Area ............................................. B-11

B-5 Soil Sampling Locations Near the 554th Range Squadron

B-6 Soil Sampling Locations Around the Range Operations

B-7 Soil Sampling Locations Around the Range Operations

B-8 Soil Sampling Locations in the Range Operations Center

B-9 Soil Sampling Locations Near the Hard Target/Depleted

Uranium Area............................................................................................... B-19

B-10 Soil Sampling Locations at the Mellan Hill Area ................................................ B-20

B-11 Various On-Site Soil Sampling Locations ................................................................ B-21

\section{TABLES}

B-1 Radiological Results of Off-Site Soil Sampling, 1995 ............................................ B-6

B-2 Radiological Results of Perimeter Soil Sampling, 1995 ....................................... B-8

B-3 Radiological Results of On-Base Housing Soil Sampling, 1995............................... B-10

B-4 Radiological Results of South Plume Area Soil Sampling, 1995 ............................... B-12

B-5 Radiological Results of 554th Range O\&M Complex

Soil Sampling, 1995................................................................................................ B-14

B-6 Radiological Results of Range Operations Center Soil

B-7 Radiological Results of Various On-Site Soil Sampling

B-8 Thermoluminescent Dosimeter Results for the Tonopah Test Range....................... B-23 
This page intentionally blank 


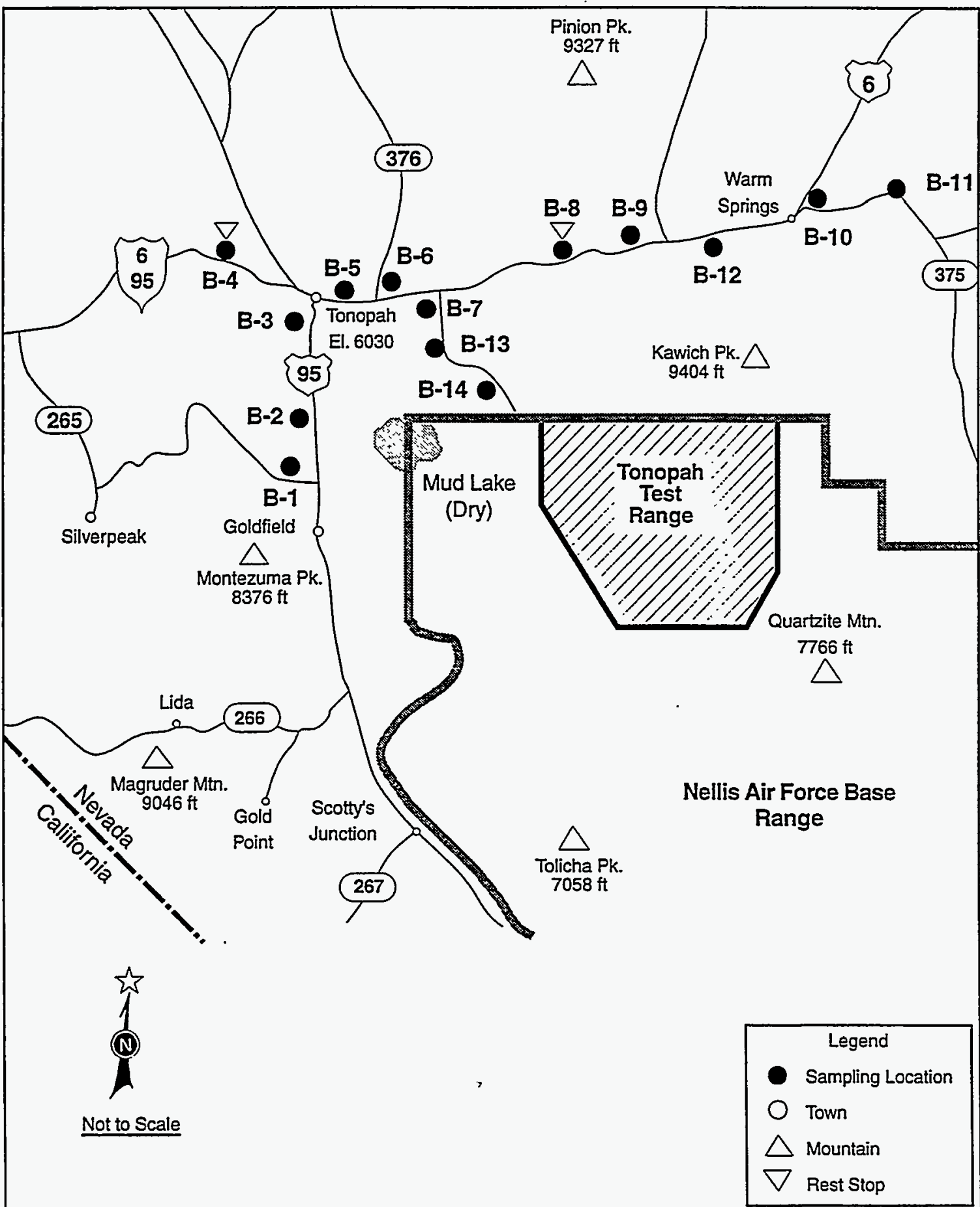

Figure B-1. Off-Site Soil Sampling Locations 
Table B-1. Radiological Results of Off-Site Soil Sampling, 1995.

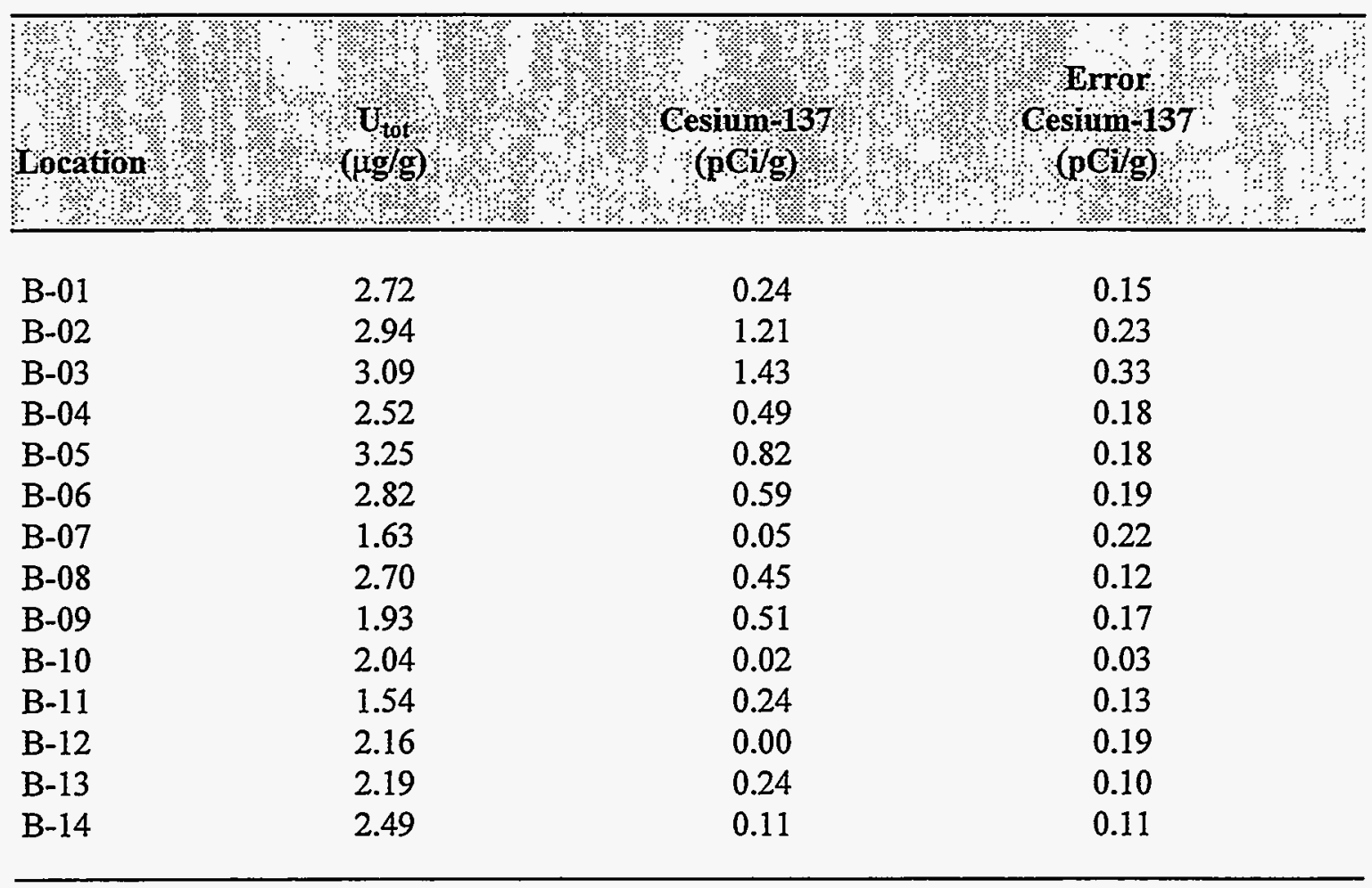


$A P P E N D L X B$

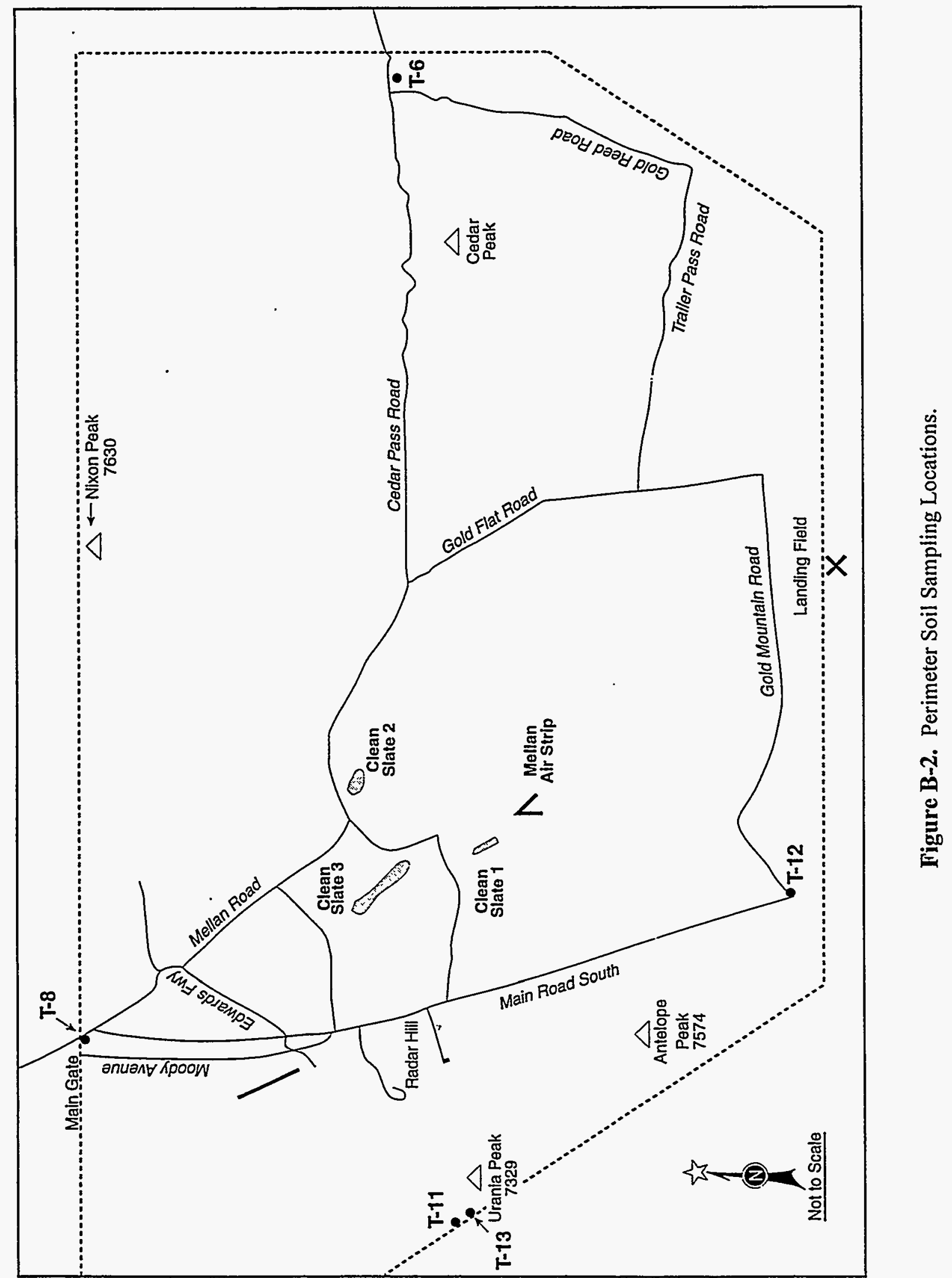


Table B-2. Radiological Results of Perimeter Soil Sampling, 1995.

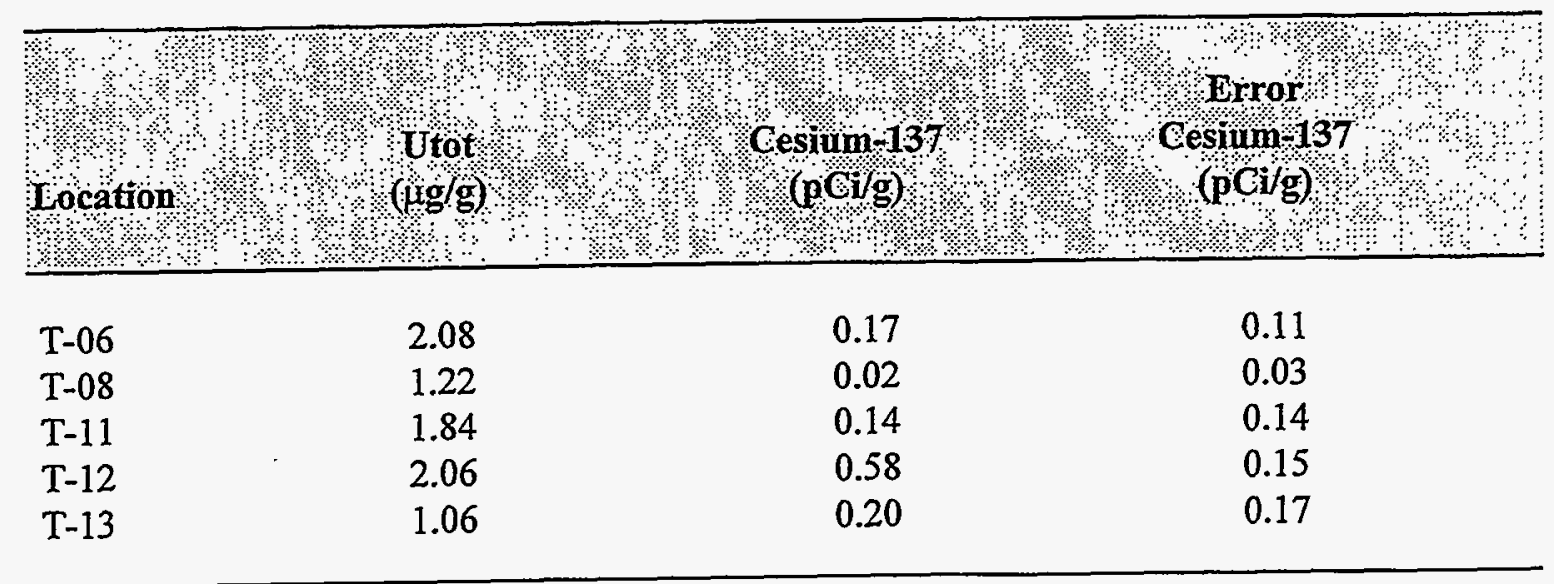




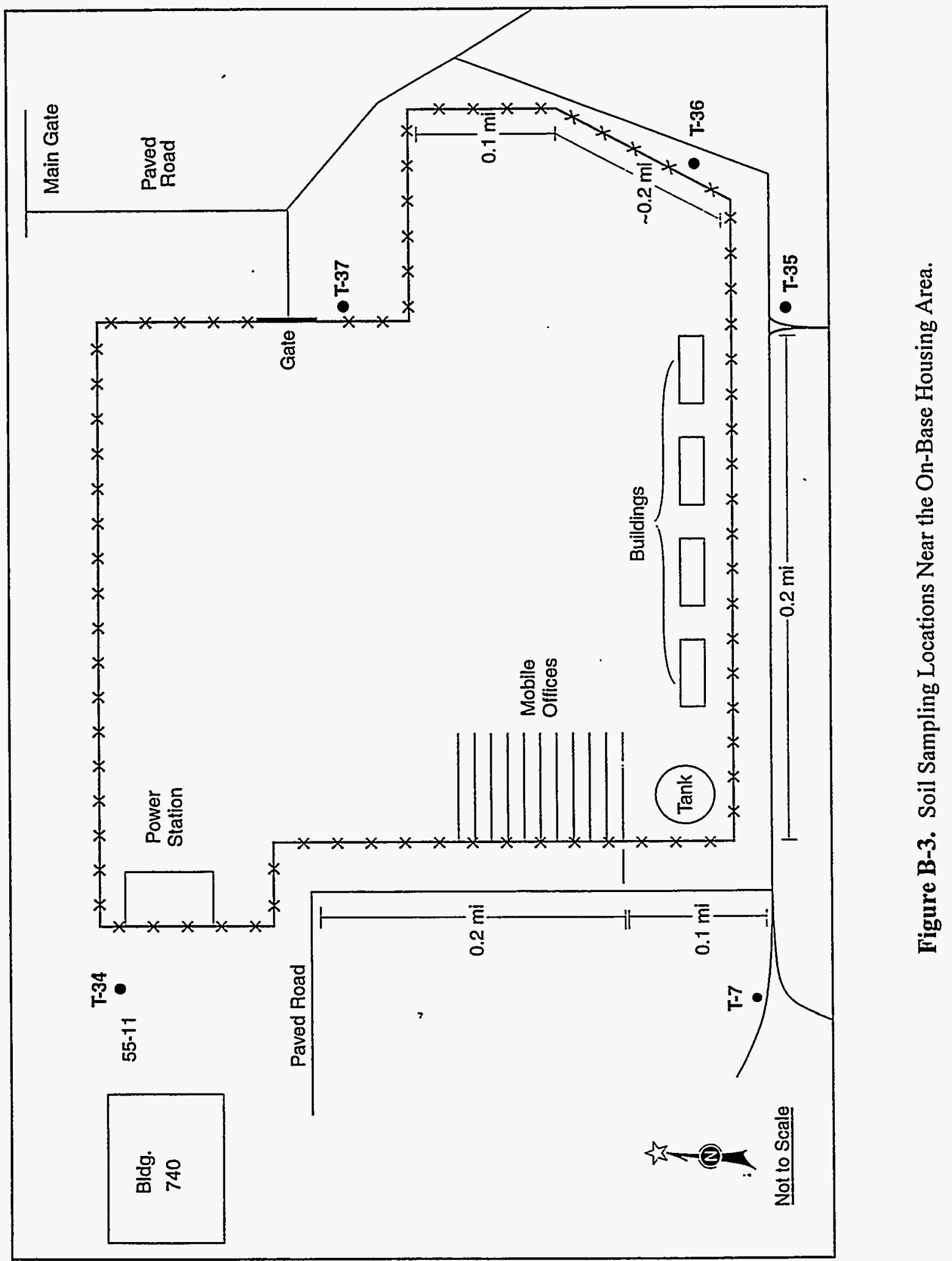


Table B-3. Radiological Results of On-Base Housing Soil Sampling, 1995.

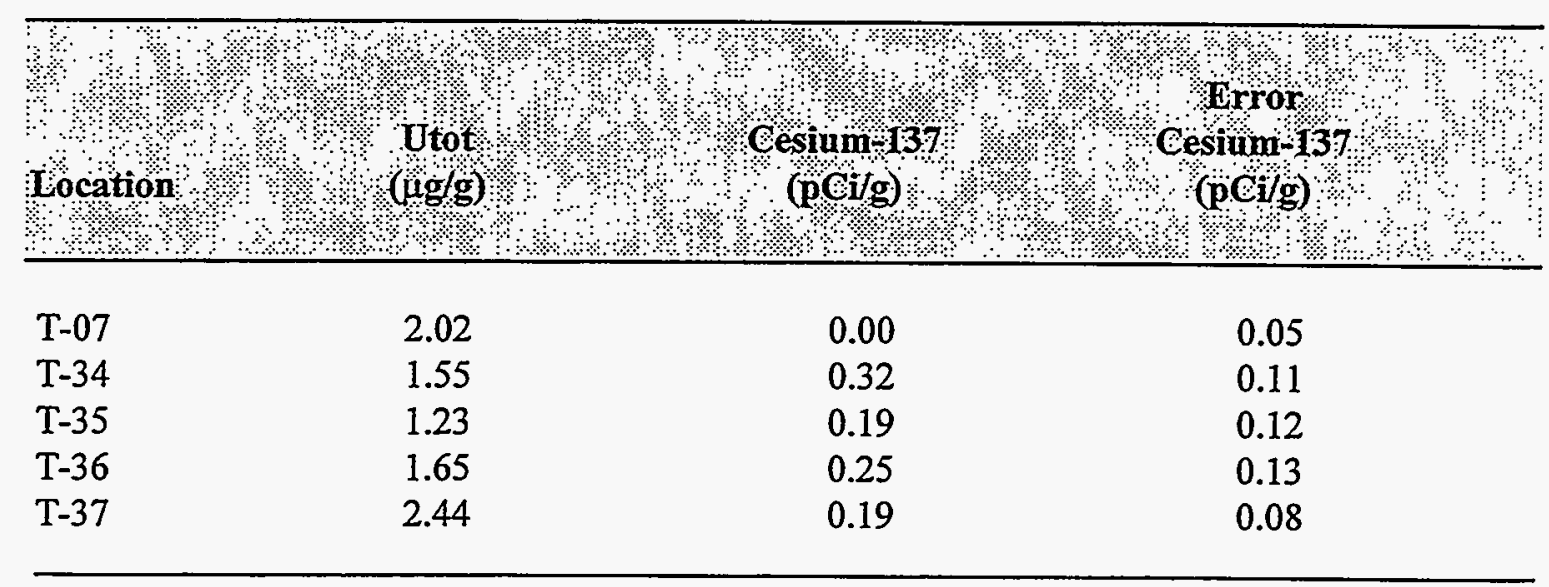




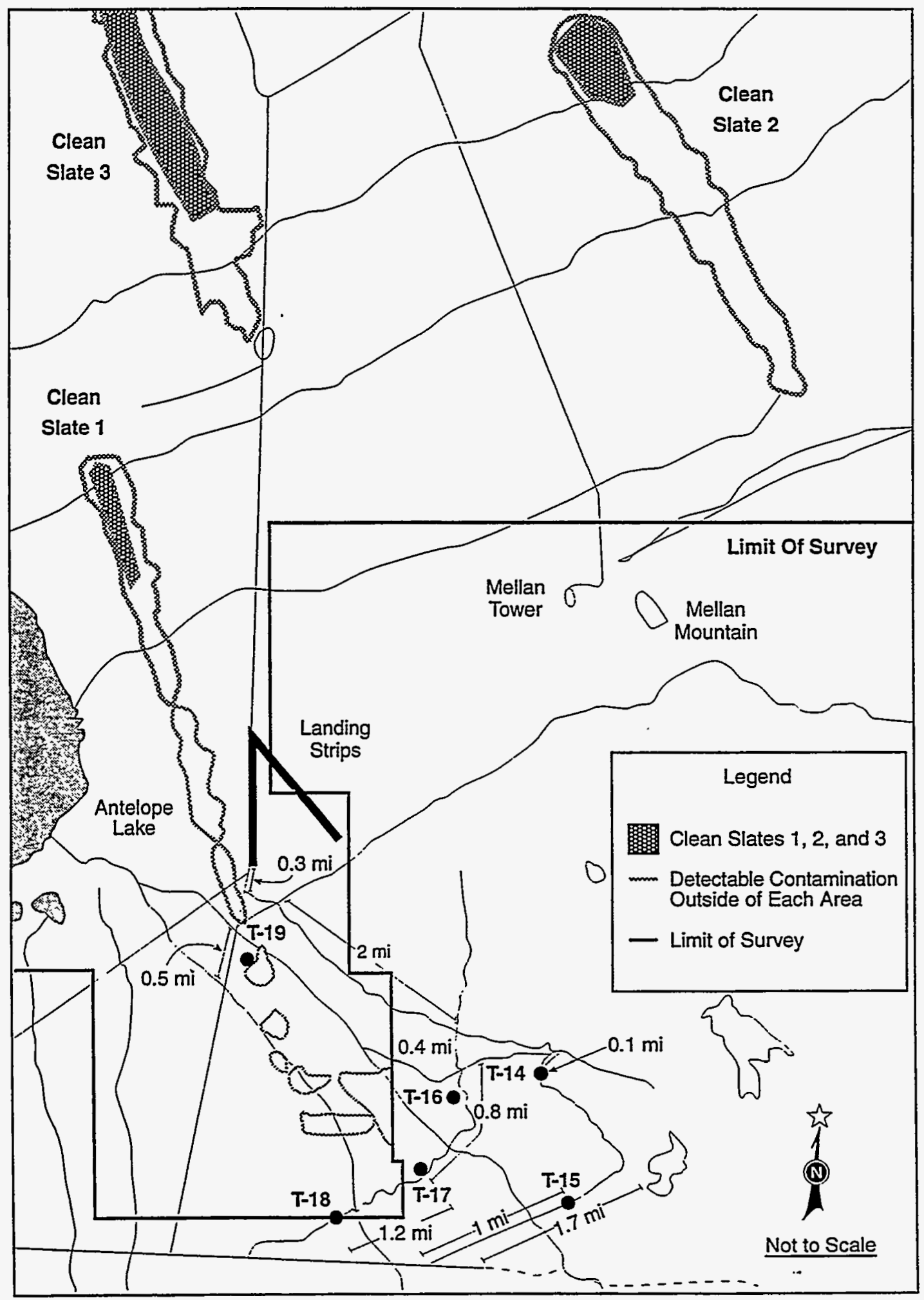

Figure B-4. Soil Sampling Locations in the South Plume Area 
Table B-4. Radiological Results of South Plume Area Soil Sampling, 1995.

\begin{tabular}{lll}
\hline \\
1
\end{tabular}




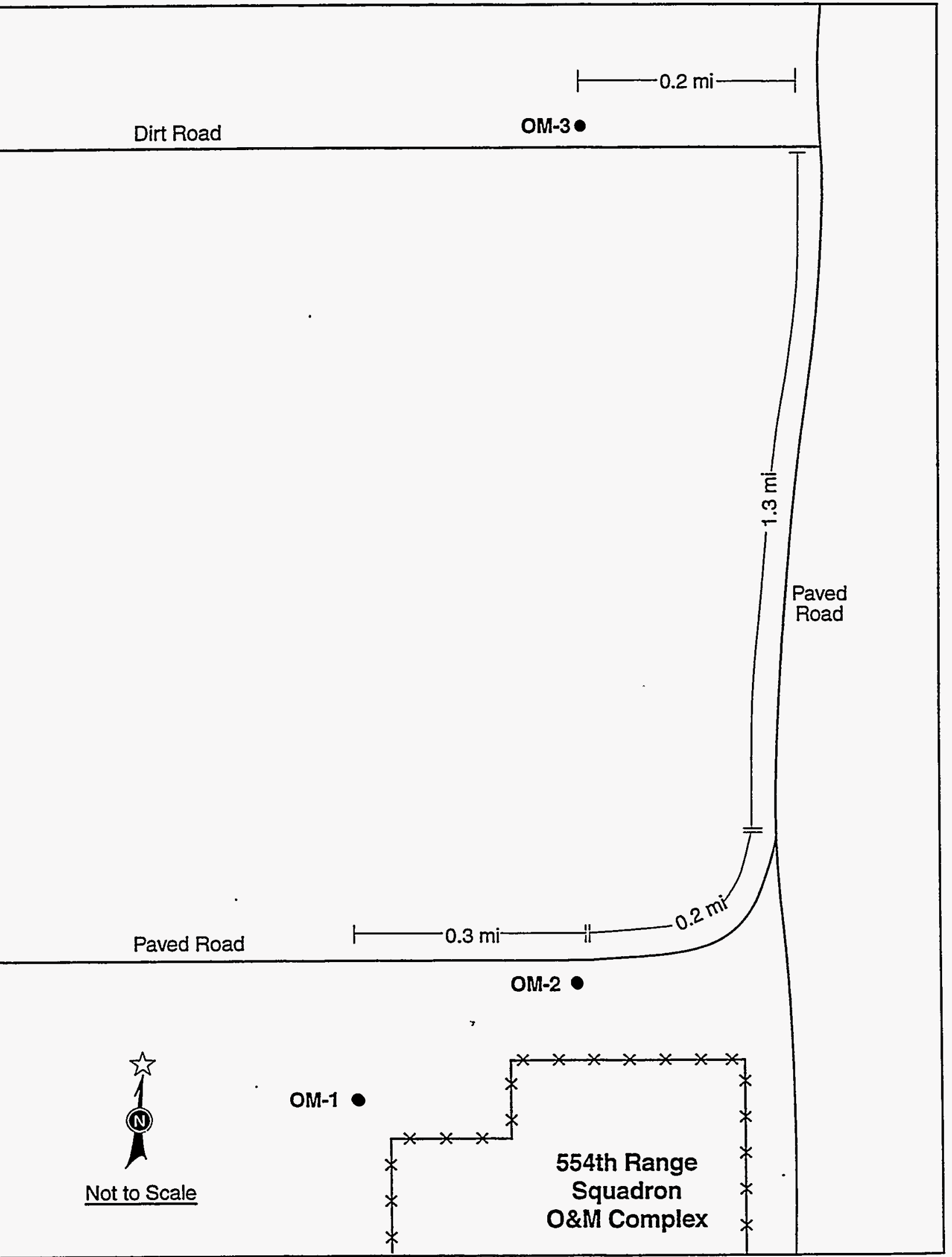

Figure B-5. Soil Sampling Locations Near the 554th Range Squadron O\&M Complex.

B-13 
Table B-5. Radiological Results of 554th Range Squadron O\&M Complex Soil Sampling, 1995.

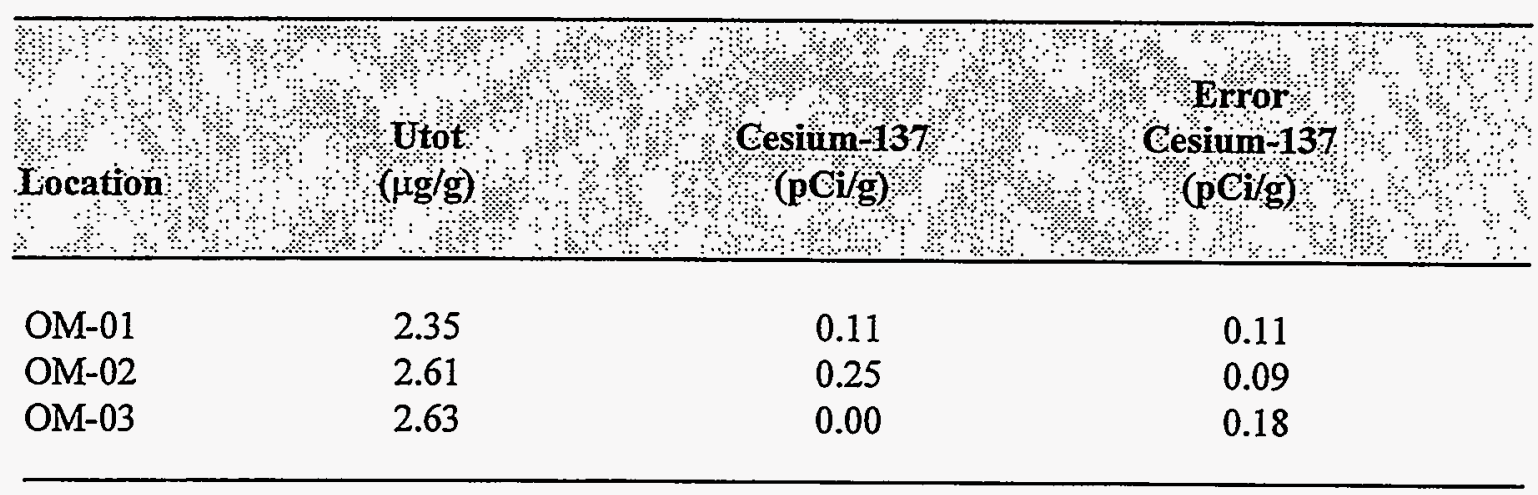




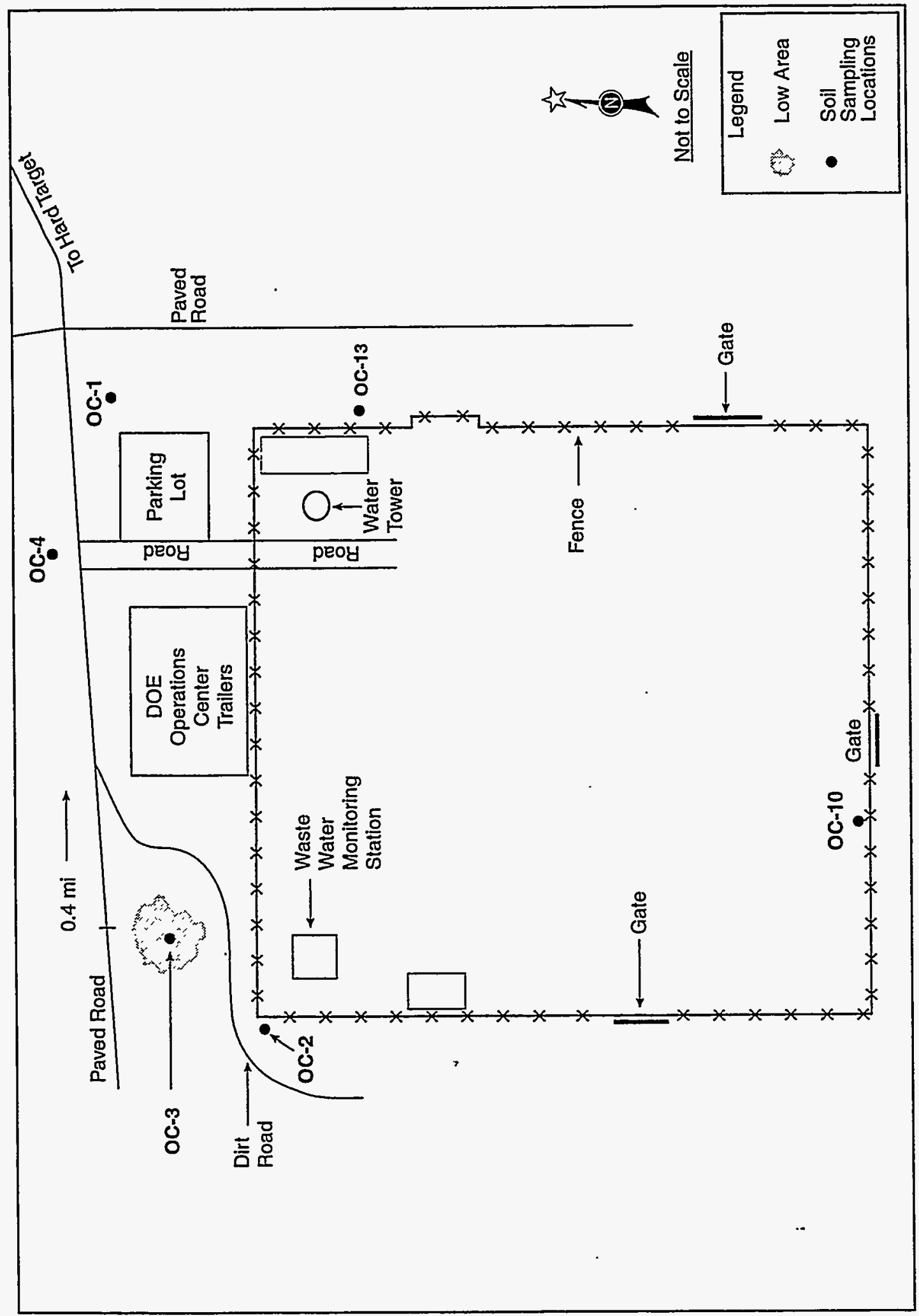

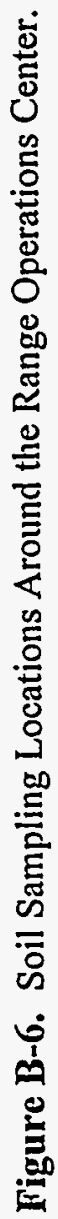




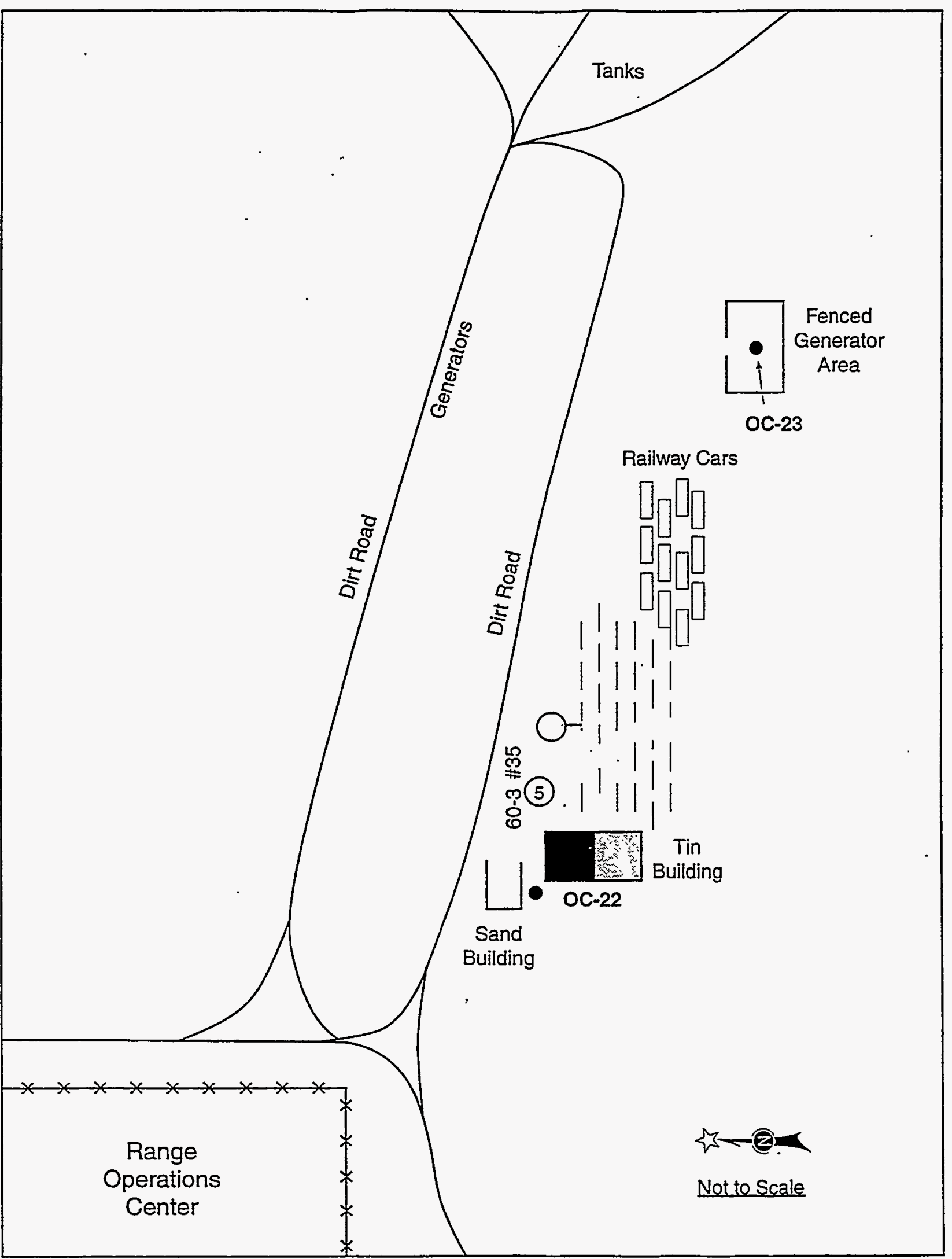

Figure B-7. Soil Sampling Locations Around the Range Operations Center Storage Yard. 


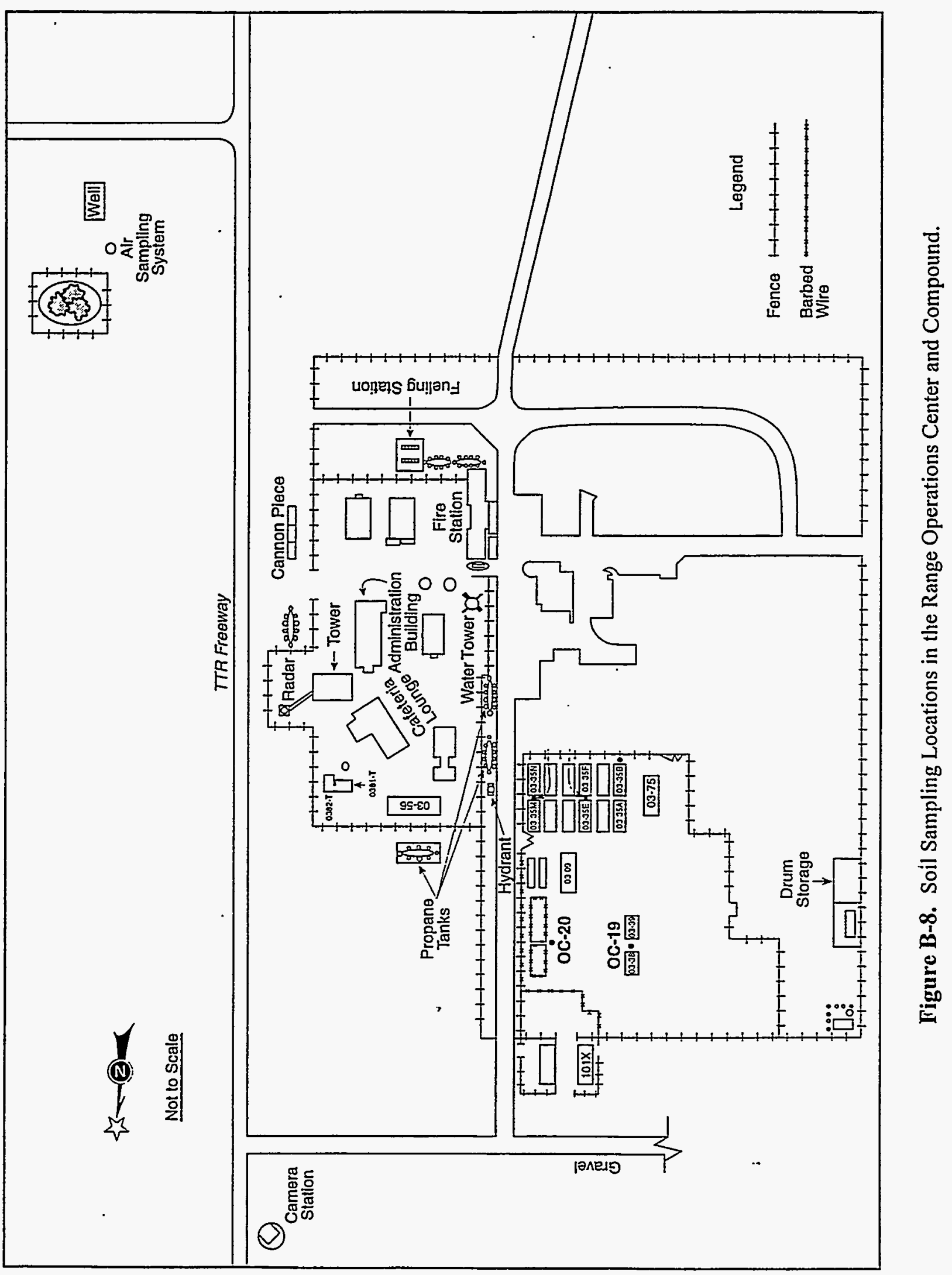


Table B-6. Radiological Results of Range Operations Center Soil Sampling, 1995.

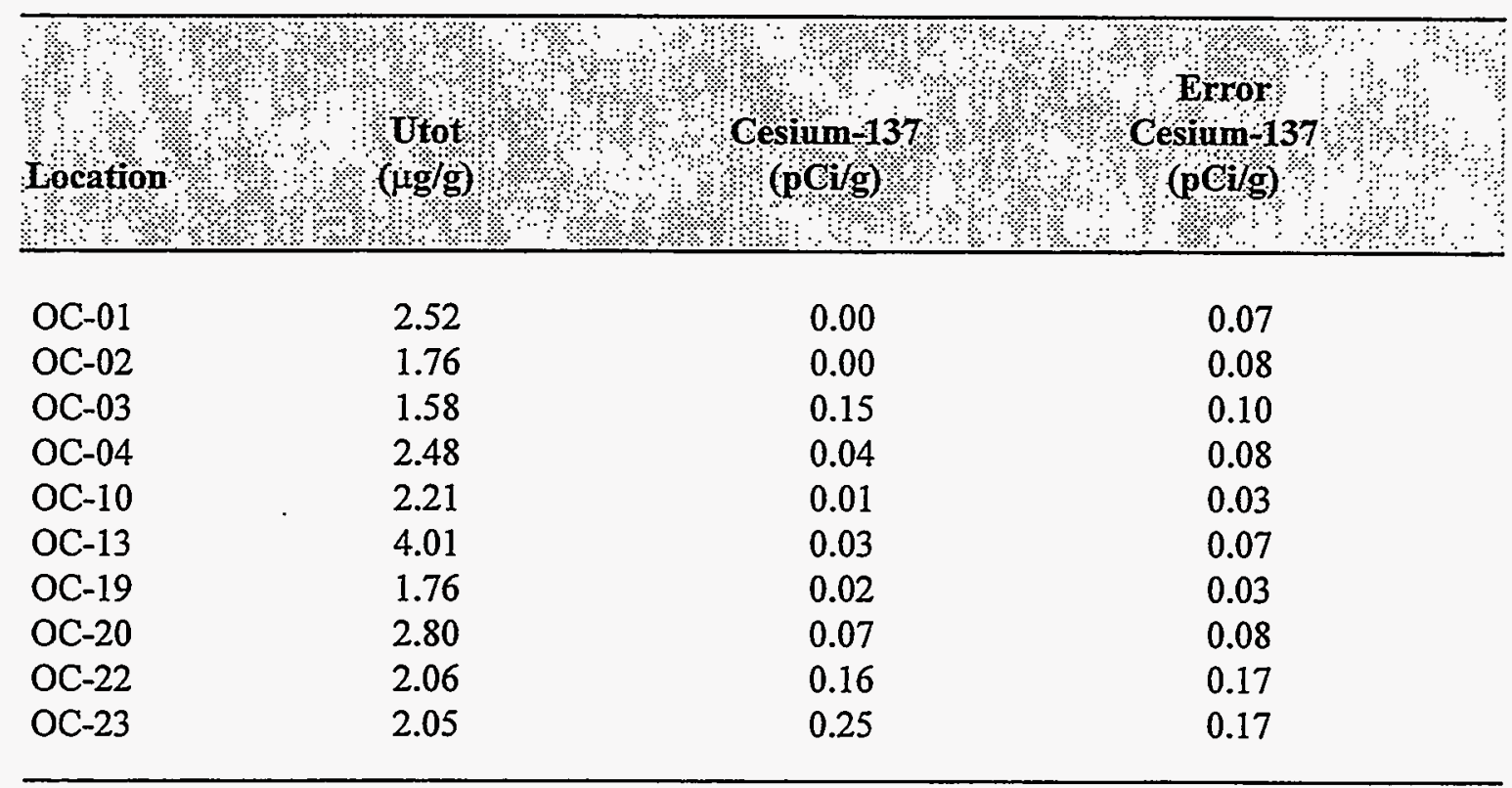



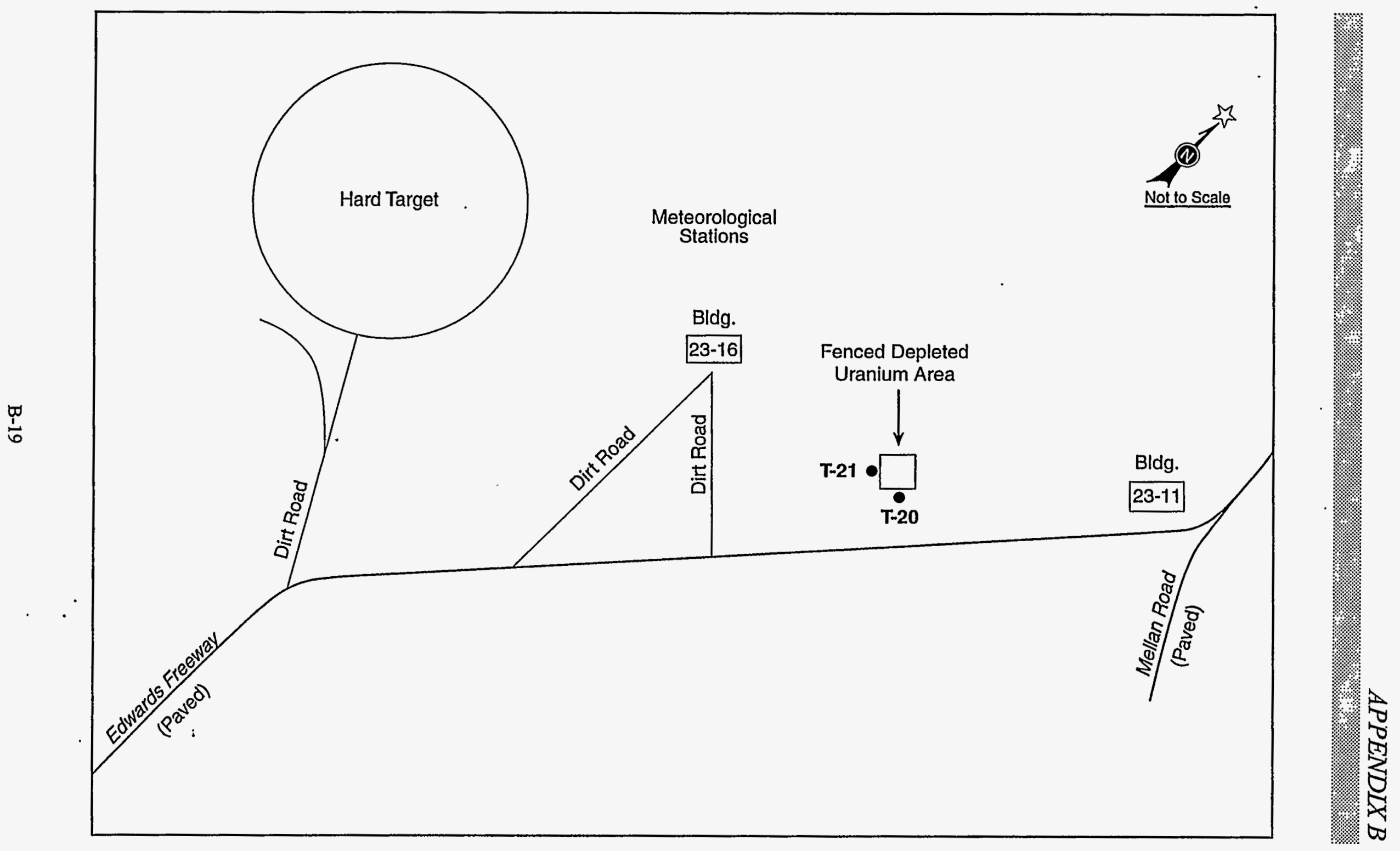

Figure B-9. Soil Sampling Locations Near the Hard Target/Depleted Uranium Area. 


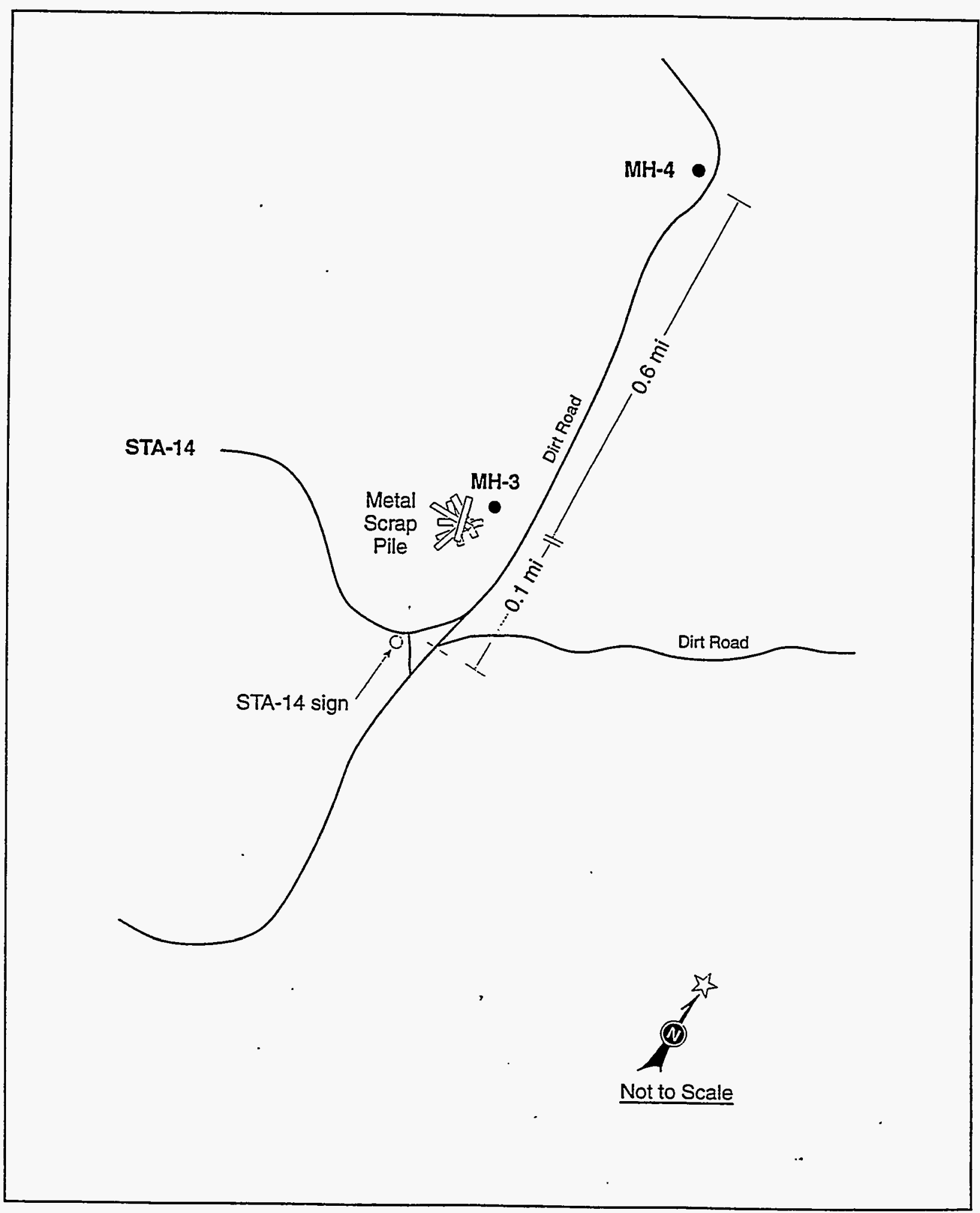

Figure B-10. Soil Sampling Locations at the Mellan Hill Area. 


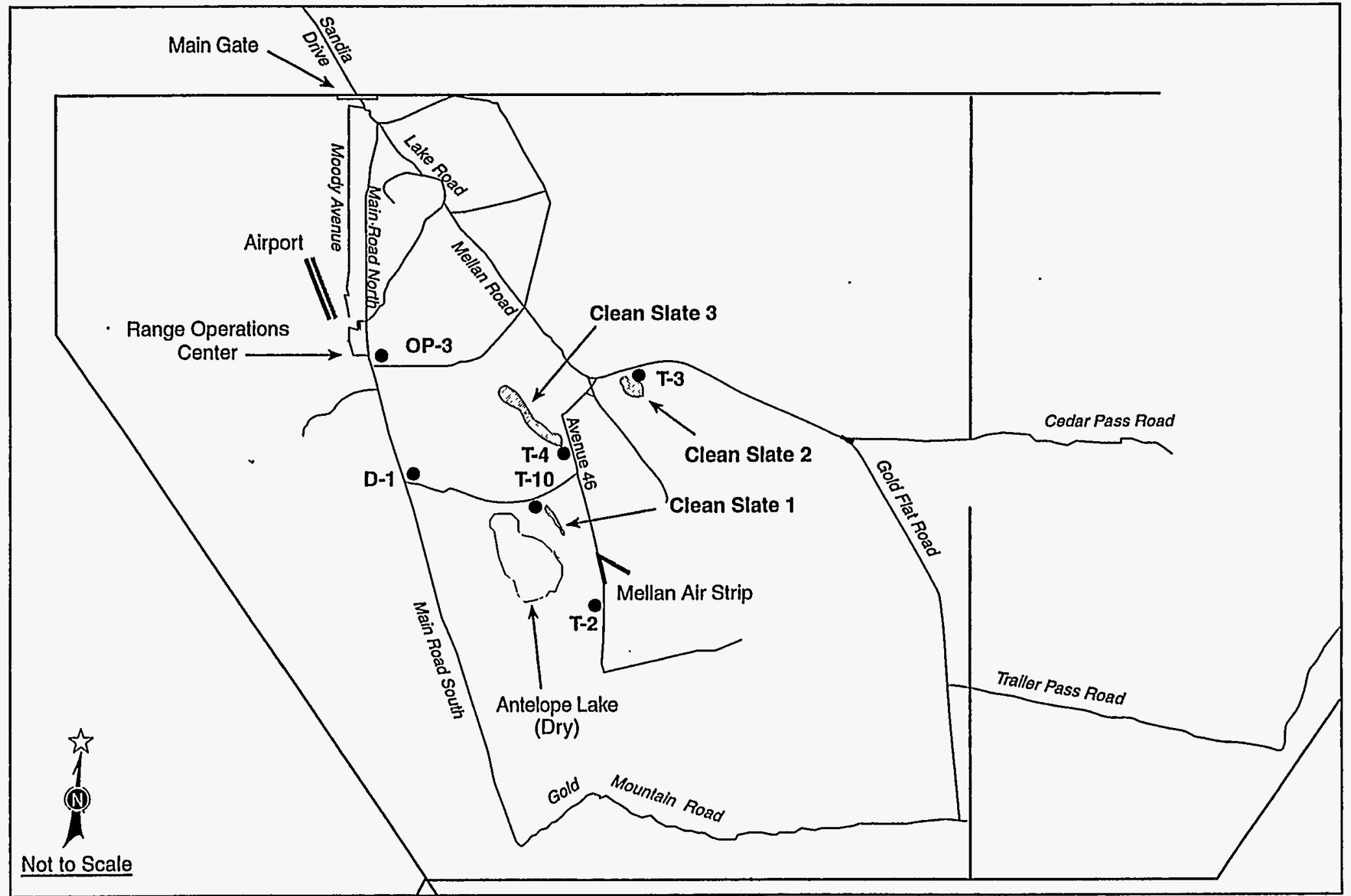

Figure B-11. Various On-Site Soil Sampling Locations. 
Table B-7. Radiological Results of Various On-Site Soil Sampling Locations, 1995.

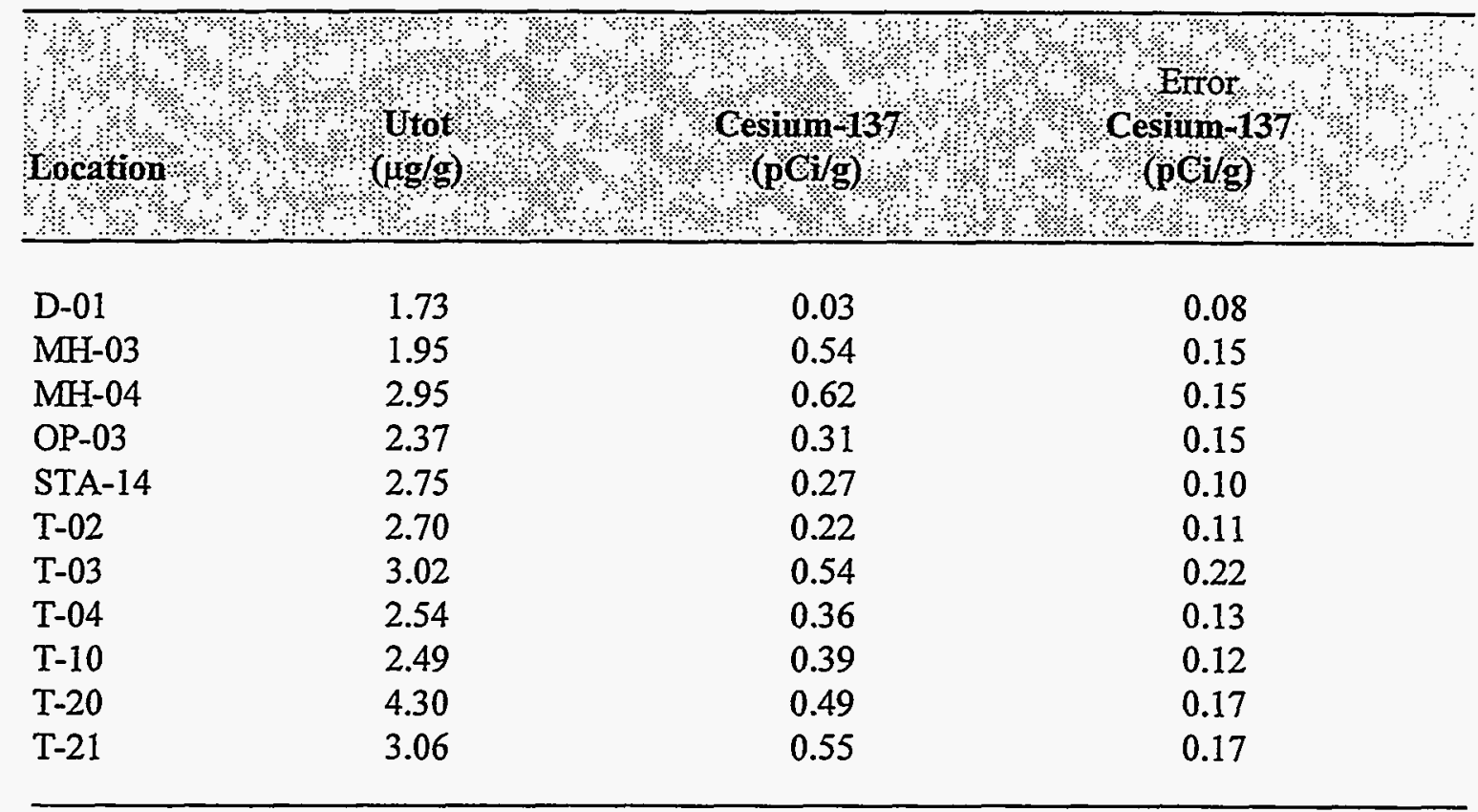


Table B-8. Thermoluminescent Dosimeter Results for the Tonopah Test Range.

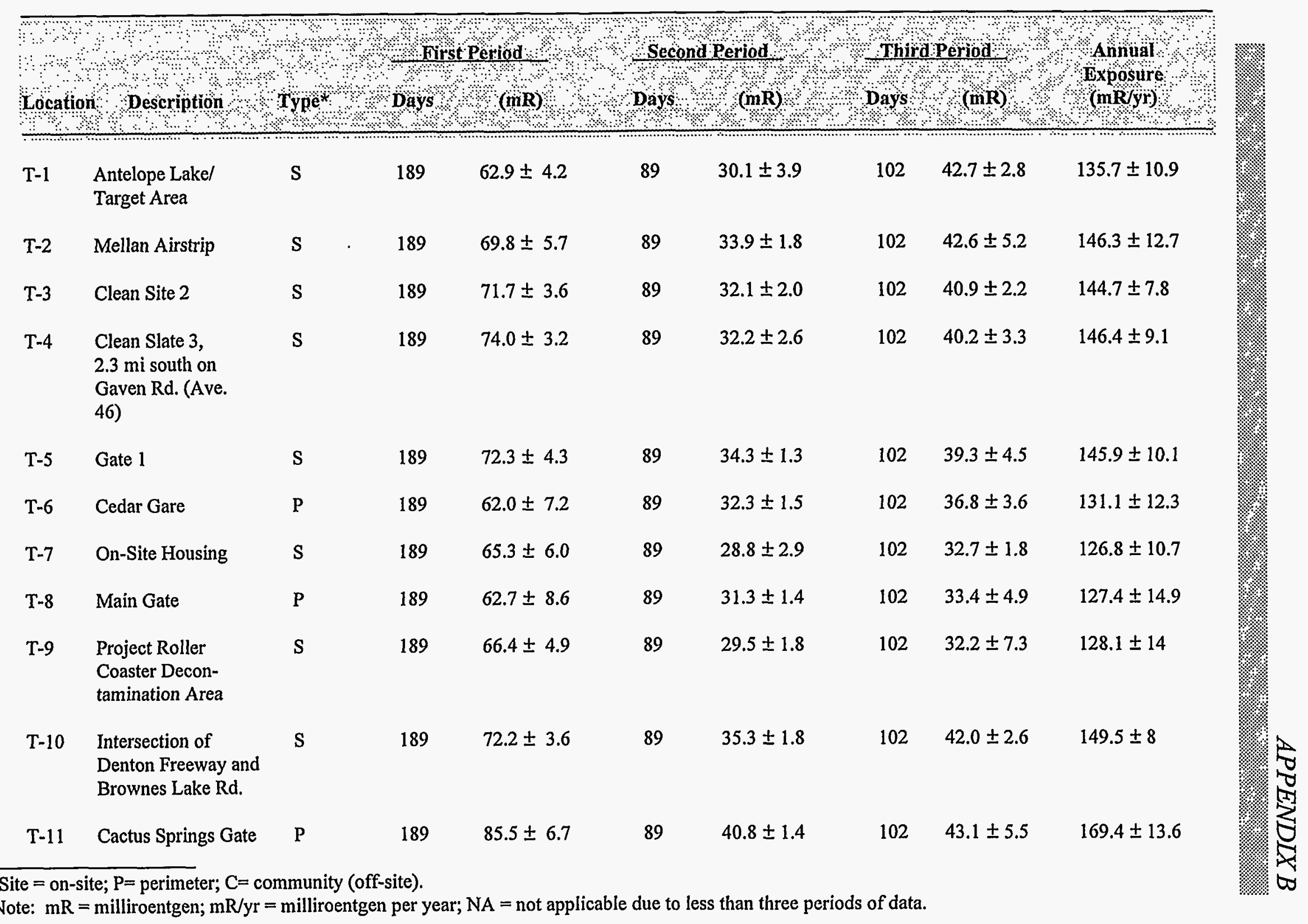




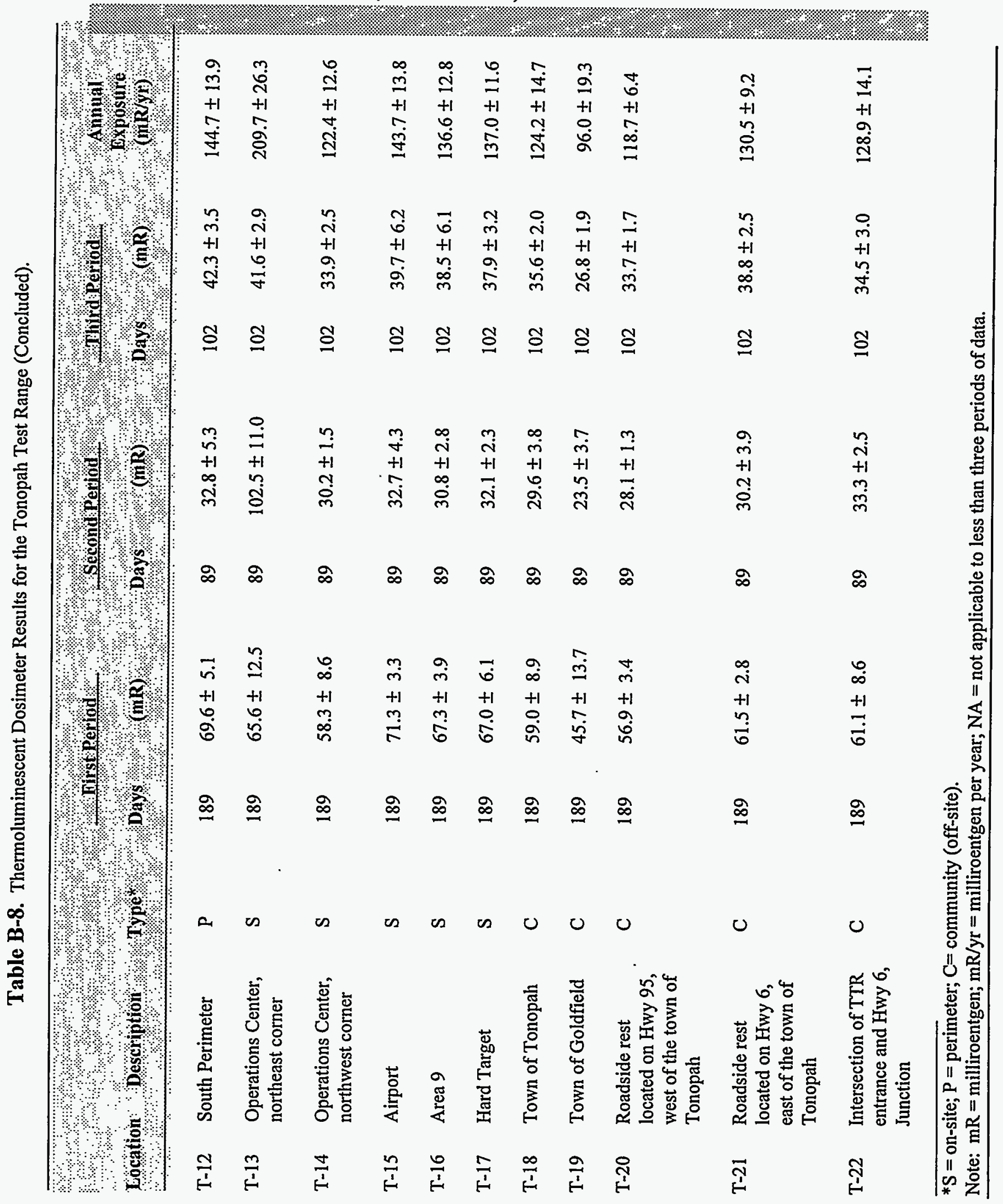




\section{APPENDIX C}

NON-RADIOLOGICAL ANALYTICAL DATA 
This page intentionally blank

C-2 


\section{CONTENTS}

TABLES

Page

C-1 Concentrations of metals in off-site soil samples ......................................................... C-5

C-2 Concentrations of metals in perimeter soil samples ................................................... C-6

C-3 Concentrations of metals in On-Base Housing Area soil samples ............................... C-7

C-4 Concentrations of metals in South Plume Area soil samples ..................................... C-8

C-5 Concentrations of metals in the 554th Range Squadron

O\&M Complex Area soil samples .............................................................................. C-9

C-6 Concentrations of metals in the Range Operations Center and Compound soil samples ....................................................................................... C-10

C-7 Concentrations of metals in Soil Samples from various on-site locations. 
This page intentionally blank 
Table C-1. Concentrations (in $\mu \mathrm{g} / \mathrm{g}$ ) of metals in off-site soil samples.

\begin{tabular}{|c|c|c|c|c|c|c|c|c|c|c|}
\hline \multicolumn{11}{|c|}{ 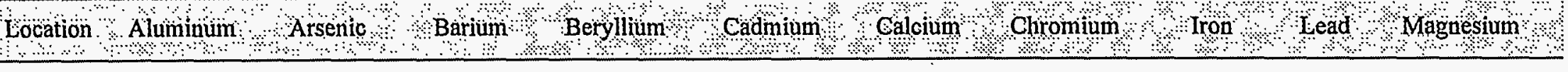 } \\
\hline B-01 & 10400 & 28 & 129 & 0.5 & 0.5 & 18500 & 6 & 13700 & 20 & 4020 \\
\hline B-02 & 8820 & 26 & 116 & 0.5 & 0.5 & 17700 & 6 & 12000 & 23 & 4180 \\
\hline B-03 & 11400 & 14 & 154 & 0.5 & 0.5 & 13100 & 6 & 13000 & 34 & 4560 \\
\hline B-04 & 5250 & 13 & 73 & 0.5 & 0.5 & 6430 & 4 & 7410 & 16 & 3180 \\
\hline B-05 & 12700 & 26 & 164 & 0.5 & 0.5 & 31800 & 11 & 16800 & 21 & 7680 \\
\hline B-06 & 7850 & 5 & 173 & 0.5 & 0.5 & 23000 & 4 & 3820 & 13 & 2100 \\
\hline B-07 & 6980 & 5 & 121 & 0.5 & 0.5 & 6070 & 5 & 9170 & 17 & 3080 \\
\hline B-08 & 4500 & 6 & 104 & 0.5 & 0.5 & 2200 & 4 & 6060 & 15 & 1730 \\
\hline B-09 & 4880 & 5 & 97 & 0.5 & 0.5 & 1720 & 3 & 5930 & 16 & 1680 \\
\hline B-10 & 4290 & 6 & 109 & 0.5 & 0.5 & 31000 & 5 & 8250 & 7 & 3280 \\
\hline B-11 & 6820 & 14 & 137 & 0.5 & 0.5 & 21800 & 5 & 8320 & 10 & 3810 \\
\hline B-12 & 7880 & 5 & 155 & 0.7 & 0.5 & 5600 & 4 & 7450 & 11 & 2960 \\
\hline B-13 & 6360 & 5 & 113 & 0.5 & 0.5 & 3020 & 3 & 7100 & 10 & 2330 \\
\hline B-14 & 5320 & 5 & 85 & 0.5 & 0.5 & 1810 & 3 & 6290 & 7 & 1870 \\
\hline \multicolumn{11}{|c|}{ 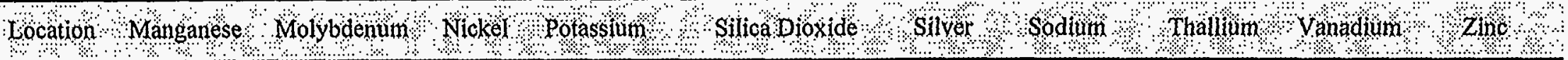 } \\
\hline B-01 & 412 & 5 & 5 & 2800 & 410 & 2 & 700 & 20 & 20 & 43 \\
\hline B-02 & 392 & 5 & 8 & 2600 & 400 & 2 & 600 & 10 & 17 & 43 \\
\hline B-03 & 551 & 5 & 6 & 3800 & 310 & 2 & 1900 & 10 & 23 & 57 \\
\hline B-04 & 244 & 5 & 4 & 1700 & 430 & 2 & 400 & 10 & 11 & 37 \\
\hline B-05 & 426 & 5 & 8 & 4000 & 360 & 3 & 1000 & 20 & 25 & 56 \\
\hline B-06 & 139 & 5 & 4 & 3400 & 390 & 3 & 500 & 10 & 5 & 18 \\
\hline B-07 & 361 & 5 & 6 & 3500 & 660 & 1 & 500 & 20 & 11 & 43 \\
\hline B-08 & 270 & 5 & 6 & 1300 & 460 & 1 & 400 & 10 & 12 & 29 \\
\hline B-09 & 224 & 5 & 4 & 500 & 440 & 1 & 400 & 10 & 6 & 25 \\
\hline B-10 & 193 & 5 & 4 & 1000 & 310 & 1 & 400 & 10 & 15 & 35 \\
\hline B-11 & 285 & 5 & 4 & 3900 & 430 & 1 & 1600 & 10 & 16 & 25 \\
\hline B-12 & 468 & 5 & 4 & 3000 & 410 & 2 & 1000 & 10 & 5 & 28 \\
\hline B-13 & 214 & 5 & 4 & 3300 & 320 & 1 & 400 & 10 & 12 & 26 \\
\hline B-14 & 140 & 5 & 4 & 2800 & 370 & 1 & 300 & 10 & 10 & 26 \\
\hline
\end{tabular}

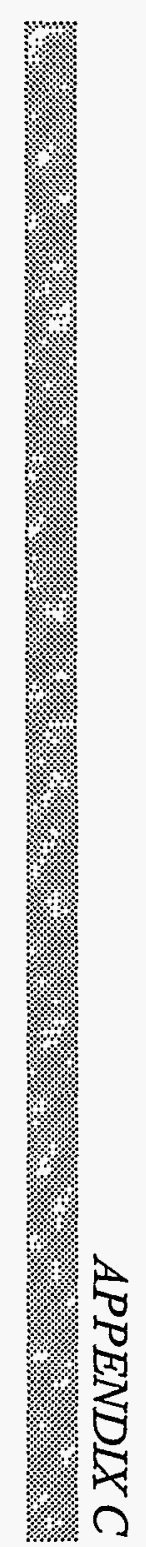


Table C-2. Concentrations (in $\mu \mathrm{g} / \mathrm{g}$ ) of metals in perimeter soil samples.

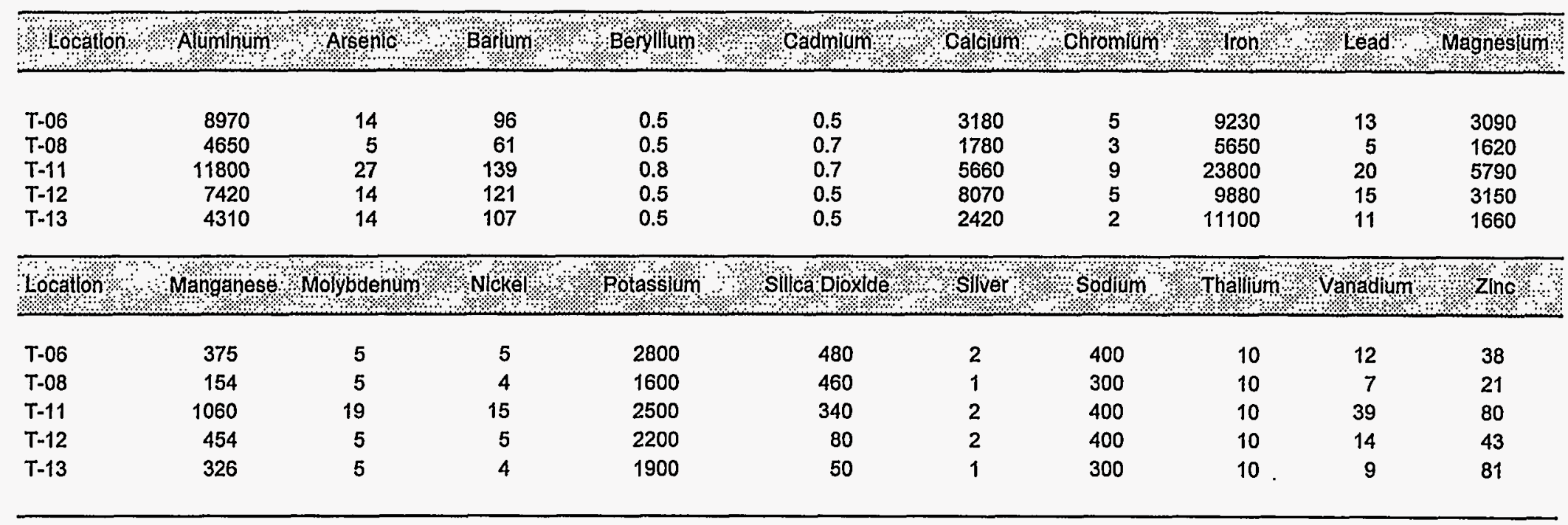


Table C-3. Concentrations (in $\mu \mathrm{g} / \mathrm{g}$ ) of metals in On-Base Housing Area soil samples.

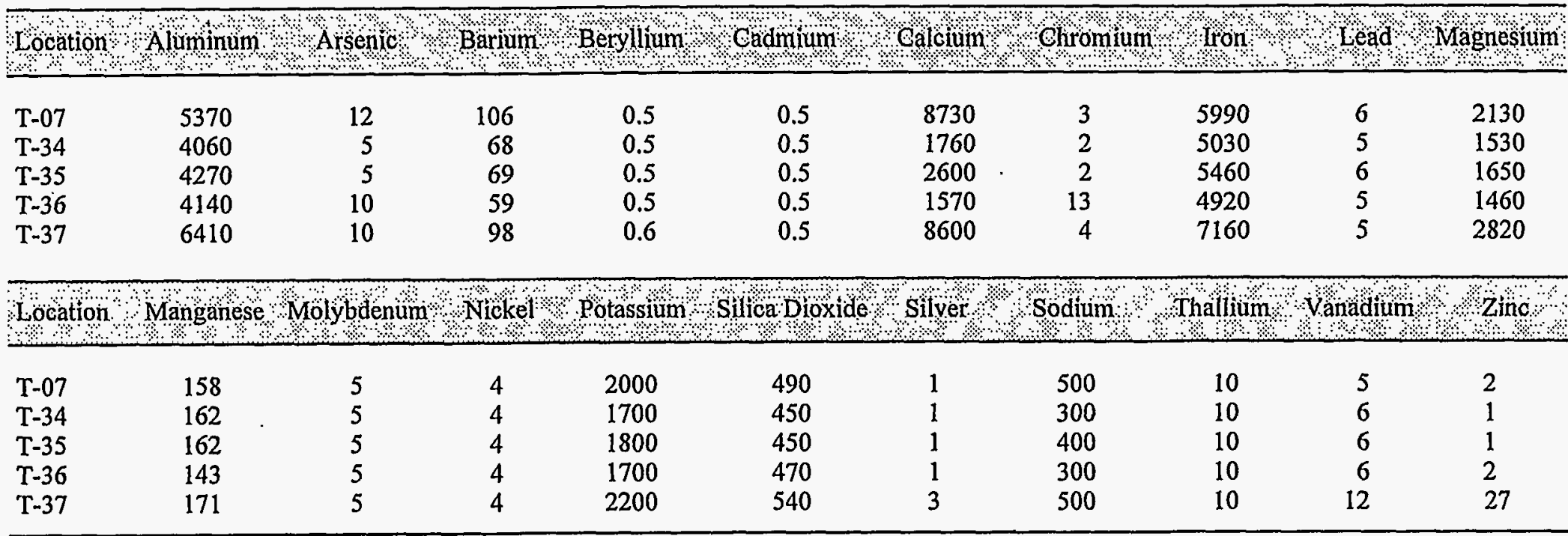


Table C-4. Concentrations (in $\mu \mathrm{g} / \mathrm{g}$ ) of metals in South Plume Area soil samples.

\begin{tabular}{|c|c|c|c|c|c|c|c|c|c|c|}
\hline \multicolumn{11}{|c|}{ Location Aluminum } \\
\hline $\mathrm{T}-14$ & 9870 & 16 & 192 & 0.5 & 0.5 & 5690 & 6 & 12400 & 10 & 3930 \\
\hline$T-15$ & 8150 & 8 & 129 & 0.5 & 0.5 & 7810 & 6 & 10200 & 8 & $\begin{array}{l}3930 \\
3760\end{array}$ \\
\hline$T-16$ & 8420 & 13 & 148 & 0.5 & 0.5 & 4470 & 5 & 10700 & 11 & 3430 \\
\hline $\mathrm{T}-17$ & 7500 & 8 & 166 & 0.5 & 0.5 & 4450 & 4 & 9020 & 14 & 3140 \\
\hline$T-18$ & 10200 & 17 & 147 & 0.5 & 0.5 & 4530 & 6 & 11300 & 16 & 3720 \\
\hline$T-19$ & 7310 & 5 & 100 & 0.5 & 0.5 & 3450 & 5 & 8540 & 10 & 2920 \\
\hline \multicolumn{11}{|c|}{ 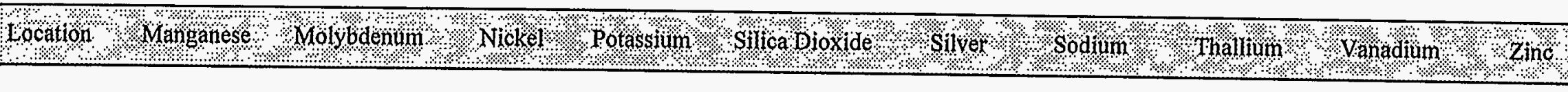 } \\
\hline $\mathrm{T}-14$ & 399 & 5 & 6 & 4500 & 70 & 5 & 700 & 10 & & \\
\hline $\mathrm{T}-15$ & 334 & 5 & 5 & 2900 & 70 & 1 & 500 & $\begin{array}{l}10 \\
10\end{array}$ & $\begin{array}{l}17 \\
16\end{array}$ & $\begin{array}{l}50 \\
40\end{array}$ \\
\hline$T-16$ & 412 & 5 & 5 & 3000 & 100 & 2 & 500 & 10 & 17 & 44 \\
\hline $\mathrm{T}-17$ & 408 & 5 & 4 & 3300 & 130 & 2 & 500 & 20 & 14 & 37 \\
\hline$T-18$ & 408 & 5 & 5 & 4600 & 150 & 5 & 700 & 20 & 16 & 43 \\
\hline $\mathrm{T}-19$ & 363 & 5 & 9 & 3000 & 960 & 1 & 600 & 20 & 13 & 35 \\
\hline
\end{tabular}


Table C-5. Concentrations (in $\mu \mathrm{g} / \mathrm{g}$ ) of metals in the 554th Range Squadron O\&M soil samples.

\begin{tabular}{|c|c|c|c|c|c|c|c|c|c|c|}
\hline \multicolumn{11}{|c|}{ Location Alưninum Arsentus } \\
\hline OM-01 & 5910 & 8 & 60 & 0.5 & 0.5 & 1520 & 2 & 5460 & 8 & 1430 \\
\hline OM-02 & 9710 & 13 & 84 & 0.5 & 0.5 & 3130 & 4 & 8750 & 13 & 2740 \\
\hline OM-03 & 6380 & 8 & 86 & 0.5 & 0.7 & 2520 & 3 & 7120 & 12 & 2220 \\
\hline \multicolumn{11}{|c|}{ 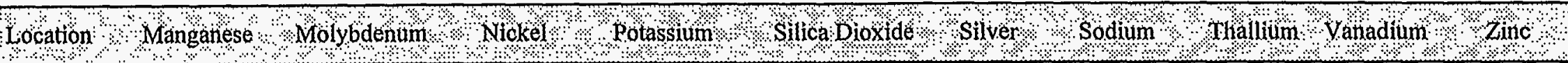 } \\
\hline OM-01 & 180 & 5 & 4 & 2000 & 290 & 1 & 400 & 10 & 5 & 21 \\
\hline OM-02 & 281 & 5 & 4 & 3500 & 360 & 2 & 400 & 10 & 11 & 31 \\
\hline $\mathrm{OM}-03$ & 317 & 5 & 4 & 1900 & 260 & 2 & 300 & 10 & 10 & 27 \\
\hline
\end{tabular}


Table C-6. Concentrations (in $\mu \mathrm{g} / \mathrm{g}$ ) of metals in the Range Operations Center and Compound soil samples.

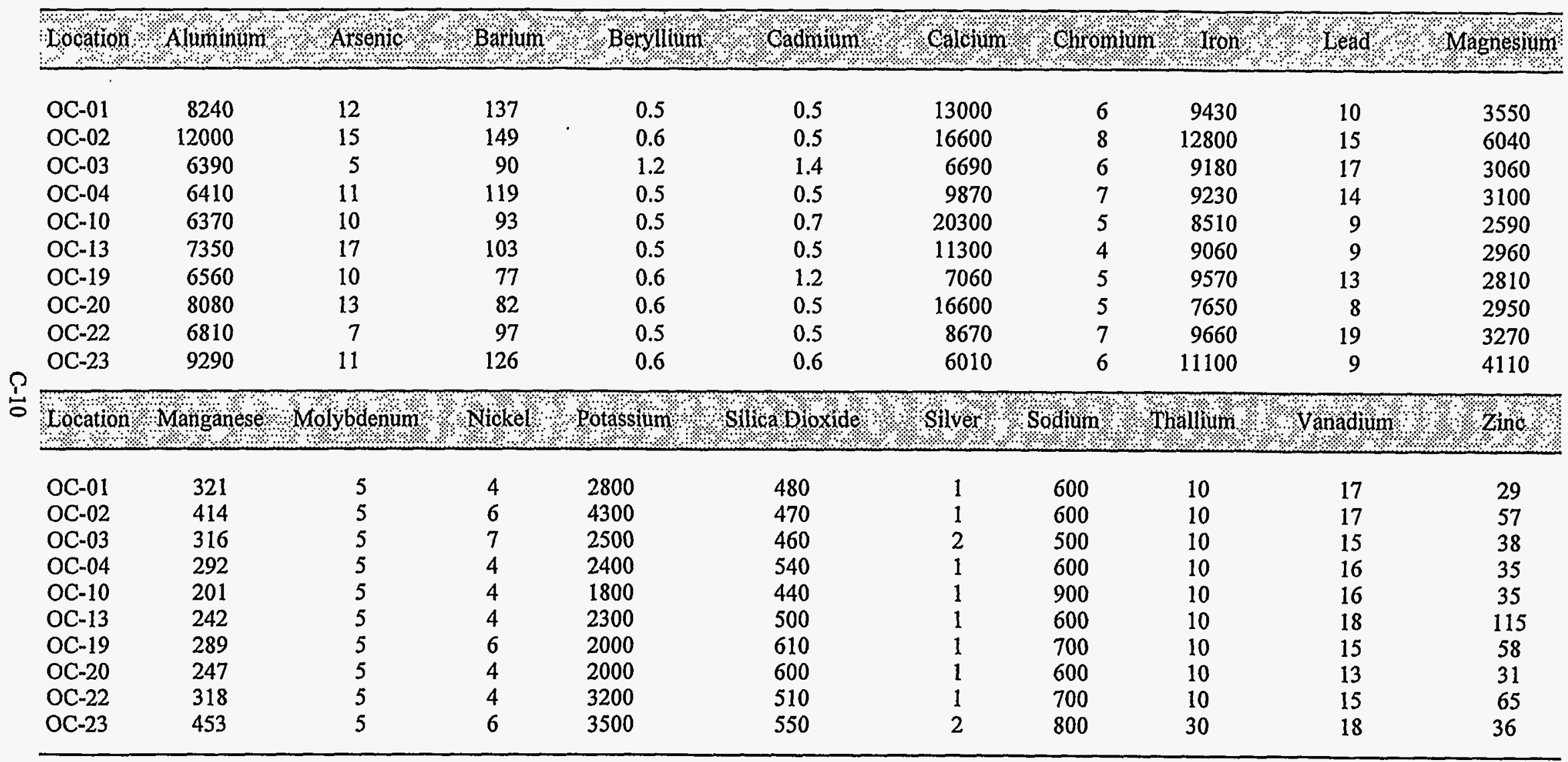


Table C-7. Concentrations (in $\mu \mathrm{g} / \mathrm{g}$ ) of metals in soil samples from various on-site locations.

\begin{tabular}{|c|c|c|c|c|c|c|c|c|c|c|}
\hline \multicolumn{11}{|c|}{ 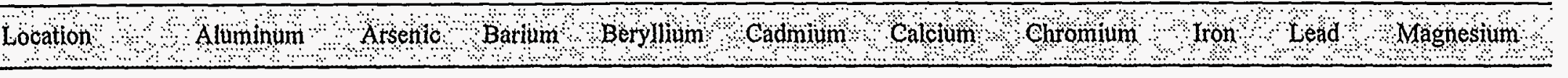 } \\
\hline D-1 & 8190 & 10 & 143 & 0.5 & 0.5 & 6080 & 5 & 14700 & 12 & 4090 \\
\hline MH-03 & 10300 & 20 & .99 & 0.5 & 0.5 & 5060 & 7 & 11300 & 11 & 4030 \\
\hline $\mathrm{MH}-04$ & 9670 & 14 & 117 & 0.5 & 0.6 & 4570 & 5 & 12100 & 13 & 3750 \\
\hline OP-03 & 8080 & 17 & 88 & 0.5 & 0.5 & 18300 & 5 & 9880 & 9 & 3440 \\
\hline STA-14 & 7990 & 13 & 106 & 0.5 & 0.5 & 8800 & 6 & 12000 & 16 & 3360 \\
\hline $\mathrm{T}-02$ & 8970 & 12 & 87 & 0.5 & 0.5 & 3450 & 4 & 8420 & 11 & 3000 \\
\hline $\mathrm{T}-03$ & 8010 & 14 & 88 & 0.5 & 0.5 & 2230 & 4 & 8640 & 13 & 2450 \\
\hline$T-04$ & 6070 & 9 & 92 & 0.5 & 0.5 & 2900 & 3 & 7560 & 11 & 2630 \\
\hline$T-10$ & 9950 & 5 & 118 & 0.5 & 0.5 & 6280 & 6 & 10800 & 9 & 4160 \\
\hline $\mathrm{T}-20$ & 11900 & 17 & 125 & 0.5 & 0.5 & 10800 & 7 & 11400 & 14 & 5660 \\
\hline $\mathrm{T}-21$ & 21600 & 18 & 172 & 1 & 0.5 & 20500 & 11 & 19400 & 18 & 10600 \\
\hline \multicolumn{11}{|c|}{ 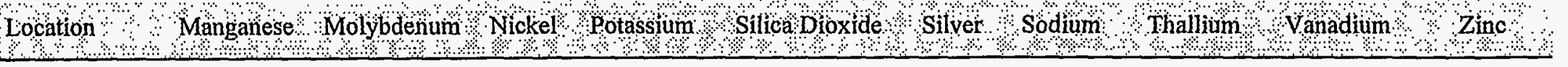 } \\
\hline D-1 & 530 & 5 & 7 & 2600 & 640 & 1 & 400 & 20 & 17 & 44 \\
\hline $\mathrm{MH}-03$ & 290 & 5 & 4 & 4100 & 370 & 2 & 400 & 10 & 17 & 47 \\
\hline MH-04 & 457 & 5 & 6 & 3100 & 500 & 2 & 600 & 10 & 16 & 42 \\
\hline OP-03 & 284 & 5 & 4 & 2600 & 520 & 1 & 600 & 10 & 14 & 31 \\
\hline STA-14 & 398 & 5 & 5 & 2900 & 440 & 2 & 600 & 10 & 17 & 38 \\
\hline $\mathrm{T}-02$ & 272 & 5 & 6 & 3200 & 450 & 1 & 400 & 10 & 11 & 38 \\
\hline $\mathrm{T}-03$ & 317 & 5 & 4 & 1800 & 390 & 2 & 400 & 10 & 12 & 27 \\
\hline $\mathrm{T}-04$ & 356 & 5 & 4 & 2000 & 380 & 1 & 400 & 10 & 10 & 27 \\
\hline $\mathrm{T}-10$ & 444 & 5 & 6 & 4000 & 630 & 2 & 600 & 10 & 15 & 43 \\
\hline $\mathrm{T}-20$ & 338 & 5 & 7 & 3900 & 670 & 2 & 600 & 10 & 17 & 36 \\
\hline $\mathrm{T}-21$ & 577 & 5 & 12 & 7800 & 980 & 4 & 2000 & 10 & 29 & 71 \\
\hline
\end{tabular}


This page intentionally blank. 


\section{UNLIMITED RELEASE DISTRIBUTION:}

U.S. Department of Energy (50)

Kirtland Area Office (KAO)

Environment, Safety, Health, and

Compliance Branch

P.O. Box 5400

Albuquerque, NM 87185

U.S. Department of Energy (1)

Nevada Operations Office

P.O. Box 98518

Las Vegas, NV 89193-8518

New Mexico Environment Department (1) c/o DOE-KAO-ESHCB

P.O. Box 5400

Albuquerque, NM 87185-5400

Albuquerque City Environmental

Services (1)

400 Marquette Ave. NW

Albuquerque, NM 87117

Captain Robert C. Viramontes (1)

2000 Wyoming Blvd.

377 ABW/EMP

KAFB, NM 87117-5606

Director (1)

Inhalation Toxicology Research Institute

P.O. Box 5800

Albuquerque, NM 87185
Environmental Protection Agency (EPA) (1)

Region IX Office

215 Fremont Street

San Francisco, CA 94105

U.S. Department of Energy/HQ, (3)

Office of Environmental Policy

and Assistance (EH-41)

1000 Independence Ave. SW

Washington, DC 20585

U.S. Department of Energy/HQ, (2)

Office of Research, Development and

Testing Facilities (DP-13)

1000 Independence Ave. SW

Washington, DC 20585

U.S. Department of Energy/HQ, (1)

Office of Environmental

Oversight (EM-22)

1000 Independence Ave. SW

Washington, DC 20585

U.S. Department of Energy/HQ, (2)

Office of Southwestern Area

Programs (EM-45)

1000 Independence Ave. SW

Washington, DC 20585

U.S. Department of Energy (3)

Albuquerque Operations Office, EPD

P.O. Box 5400

Environmental Protection Agency (EPA) (1) Albuquerque, NM 87185-5400

Headquarters Office

$401 \mathrm{M}$ Street, SW

Washington, DC 20460 
SANDIA NATIONAL LABORATORIES, INTERNAL DISTRIBUTION

1 (MS 0141) T. A. Vandenberg, 11300

1 (MS 0167) K. Kuhlmann, 12621

1 (MS 0167) A. Stotts, 12630

1 (MS 0167) A. N. Blackwell, 7000

1 (MS 0507) R. A. David, 2700

1 (MS 0658) R. G. Hay, 2723

1 (MS 0875) A. O. Bendure, 7258

5. (MS 0899) Technical Library, 4414

1 (MS 1067) G. E. Chavez, 7002

1 (MS 1303) J. R. Guth, 7573

1 (MS 1305) J. D. Fish, 7576

1 (MS 1307) J. G. Yeager, 7572

10 (MS 1309) Records Center, 7512

5 (MS 1311) T. A. Culp, 7575

1 (MS 1311) H. A. Hwang, 7575

6 (MS 1311) R. Sanchez, 7575

1 (MS 1311) L. J. Shyr, 7575

1 (MS 1311) S. J. Ward, 7511

5 (MS 1315) T. E. Blejwas, 7500

1 (MS 1347) W. B. Cox, 7581

1 (MS 1347) F. B. Nimick, 7582

1 (MS 1348) J. A. Fernandez, 7583

5 (MS 1392) L. W. Lathrop, 2719

5 (MS 1392) R. A. Smith, 2719

1 (MS 9018) Central Technical Files, 8523-2

2 (MS 0619) Review and Approval Desk, 12615 For DOE/OSTI 